Paleontology, Taphonomy, and Stratigraphy of the Browns Park Formation (Oligocene and Miocene) Near Maybell, Moffat County, Colorado

U.S. GEOLOGICAL SURVEY PROFESSIONAL PAPER 1358

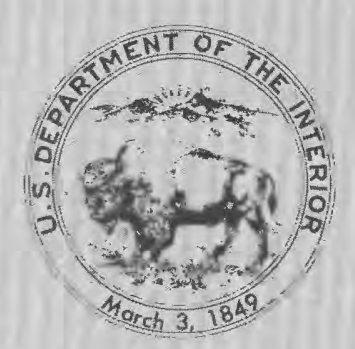




\section{Paleontology, Taphonomy, and}

Stratigraphy of the Browns Park Formation

(Oligocene and Miocene)

Near Maybell, Moffat County, Colorado

By JAMES G. HONEY and GLEN A. IZETT

U.S. GEOLOGICAL SURVEY PROFESSIONAL PAPER 1358

Descriptions of fossil mammals from the Browns

Park Formation in northwestern Colorado, with a discussion of the stratigraphy of the

formation and the burial mechanics of the fossils

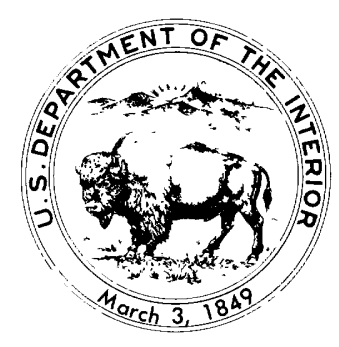

United States GOVERNMENT PRINTING OFFICE, WASHington : 1988 


\section{DEPARTMENT OF THE INTERIOR}

DONALD PAUL HODEL, Secretary

\section{U.S. GEOLOGIGAL SURVEY}

Dallas L. Peck, Director

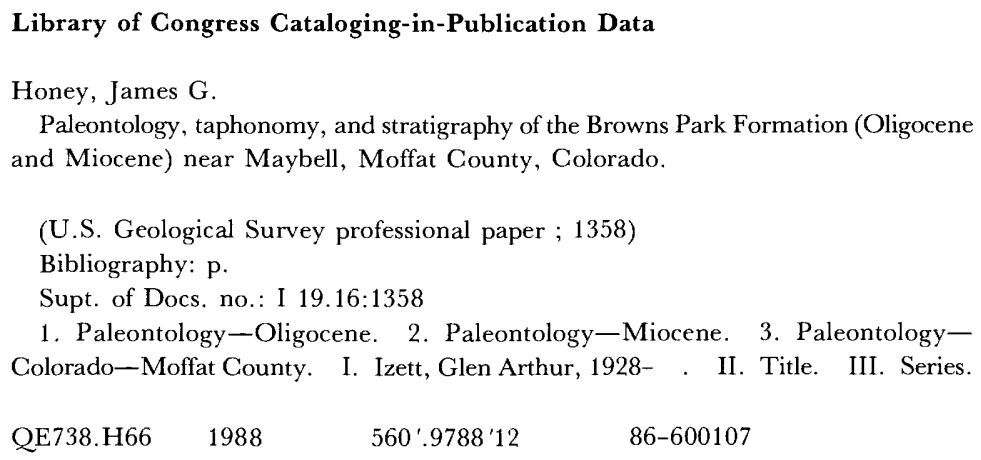

For sale by the Books and Open-File Reports Section, U.S. Geological Survey, Federal Center, Box 25425, Denver, CO 80225

Any use of trade names in this publication is for descriptive purposes only and does not imply endorsement by the U.S. Geological Survey. 


\section{CONTENTS}

Abstract $\ldots \ldots \ldots \ldots \ldots \ldots \ldots \ldots \ldots \ldots \ldots \ldots \ldots$

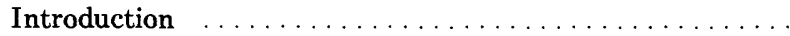

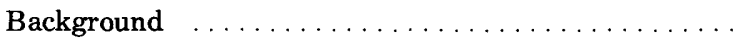

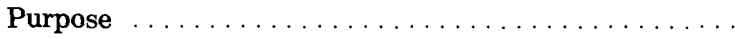

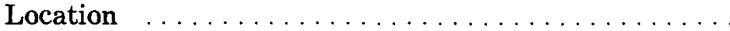

Previous investigations $\ldots \ldots \ldots \ldots \ldots \ldots \ldots$

Abbreviations . . . . . . . . . . . . . . . . .

Fieldwork and acknowledgments $\ldots \ldots \ldots \ldots \ldots \ldots$

Stratigraphy of the Browns Park Formation ..........

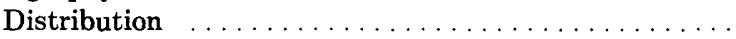

Physical characteristics and outcrop pattern ........

Geologic setting and contact relations . . . . . . . .

Lithology and sedimentary structures $\ldots \ldots \ldots \ldots \ldots$

Basal conglomerate unit . . . . . . . . . . . .

White, crossbedded sandstone unit ...........

White, parallel-bedded sandstone unit . . . . . . .

Tan sandstone unit $\ldots \ldots \ldots \ldots \ldots \ldots \ldots \ldots$

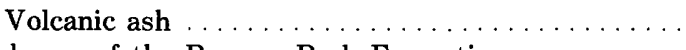

Thickness of the Browns Park Formation ..........

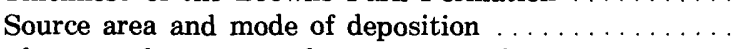

Vertebrate taphonomy of the Browns Park Formation ....

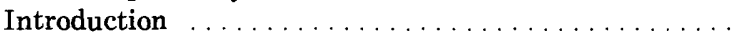

On the role of water as a dispersive agent $\ldots \ldots \ldots \ldots$

Bone orientations $\ldots \ldots \ldots \ldots \ldots \ldots \ldots \ldots$

Relative abundance of bones . . . . . . . . . .

Comparisons with locality 7498

Processes affecting destruction and dispersal of bones at

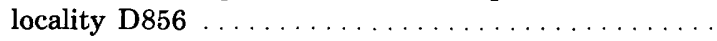

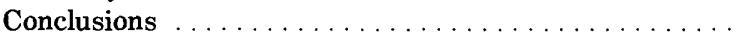

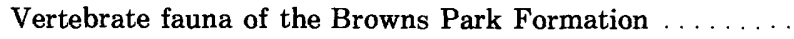

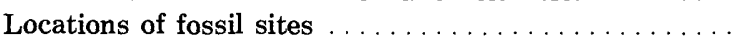

Mammalian paleontology $\ldots \ldots \ldots \ldots \ldots \ldots \ldots \ldots$

Order Carnivora Bowdich .................

Family Canidae Gray ...................

\begin{tabular}{|c|c|c|}
\hline Page & & Page \\
\hline 1 & Vertebrate fauna-Continued & \\
\hline 1 & Mammalian paleontology-Continued & \\
\hline 1 & Order Carnivora Bowdich-Continued & \\
\hline 2 & Family Canidae Gray-Continued & \\
\hline 2 & Genus Tomarctus Cope . . . . . . . . . & 20 \\
\hline 2 & Tomarctus cf. T. paula Henshaw & 20 \\
\hline 2 & Order Perissodactyla Owen $\ldots \ldots \ldots \ldots \ldots$ & 24 \\
\hline 3 & Family Equidae Gray $\ldots \ldots \ldots \ldots$ & 24 \\
\hline 4 & Genus Megahippus McGrew . . & 24 \\
\hline 4 & Megahippus sp. $\ldots \ldots$ & 24 \\
\hline 4 & Genus Parahippus Leidy . . . . . . . . & 26 \\
\hline 4 & Parahippus cf. $P$. leonensis Sellards & 26 \\
\hline 5 & Order Artiodactyla Owen $\ldots \ldots \ldots \ldots \ldots \ldots$ & 29 \\
\hline 5 & Family Cam & 29 \\
\hline 5 & ly Stenomylinae Matthew . . . . . . . & 29 \\
\hline 9 & Genus Blickomylus Frick and Taylor .. & 29 \\
\hline 9 & Blickomylus galushai Frick and & \\
\hline 10 & Taylor $\ldots \ldots \ldots \ldots \ldots \ldots$ & 29 \\
\hline 10 & Subfamily Camelinae Gray $\ldots \ldots \ldots \ldots \ldots$ & 31 \\
\hline 11 & Genus cf. Protolabis Cope ..... & 31 \\
\hline 11 & Genus Michenia Frick and Taylor & 32 \\
\hline 11 & Michenia sp. . . . . . . . . . . & 32 \\
\hline 12 & Subfamily Camelinae or Aepycamelinae ... & 35 \\
\hline 12 & Procamelus sp. or Aepycamelus sp. . . & 35 \\
\hline 13 & Subfamily Camelinae sp. $\ldots \ldots \ldots \ldots \ldots$ & 39 \\
\hline 14 & Family Antilocapridae Gray $\ldots \ldots \ldots \ldots \ldots$ & 40 \\
\hline & Subfamily Merycodontinae Matthew ..... & 40 \\
\hline 15 & Genus Meryceros Frick ............ & 40 \\
\hline 18 & Meryceros warreni (Leidy) & 40 \\
\hline 18 & Meryceros sp. . . . . . . & 41 \\
\hline 18 & Merycodontinae sp. $\ldots \ldots \ldots \ldots \ldots \ldots$ & 44 \\
\hline 20 & Mammalian age and correlation $\ldots \ldots \ldots \ldots \ldots \ldots \ldots$ & 45 \\
\hline 20 & & 48 \\
\hline 20 & References cited & 48 \\
\hline
\end{tabular}

\section{ILLUSTRATIONS}

Figure 1. Index map showing distribution of the Browns Park Formation in northwest Colorado $\ldots \ldots \ldots \ldots \ldots \ldots$

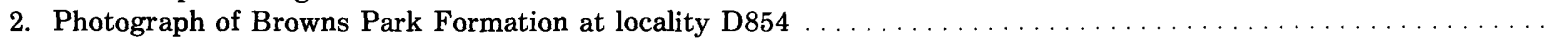

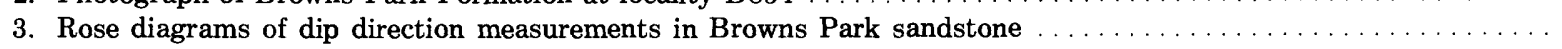

4. Stereographic and rose diagrams showing bone orientations at locality D856 quarry $\ldots \ldots \ldots \ldots \ldots \ldots \ldots$

5. Stereographic and rose diagrams showing bone orientations at UALP locality $7498 \ldots \ldots \ldots \ldots \ldots \ldots$

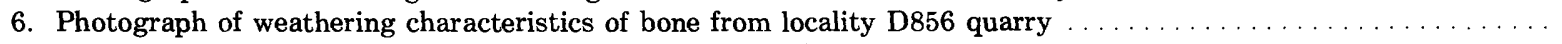

7. Map showing fossil mammal localities southwest of Maybell, Colo. 
Figure 8-18. Photographs:
8. Tomarctus ef. T. paula
9. Megahippus sp.
11. Blickomylus galushai

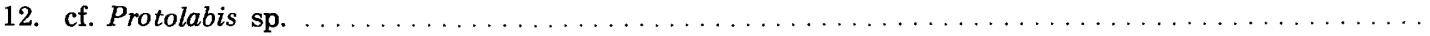

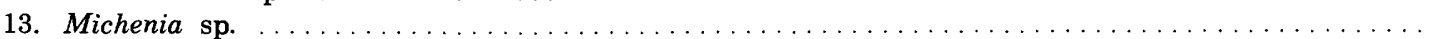

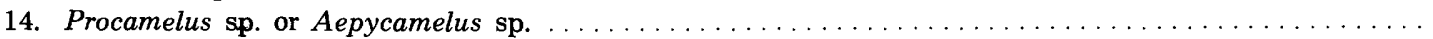

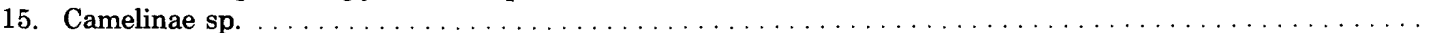

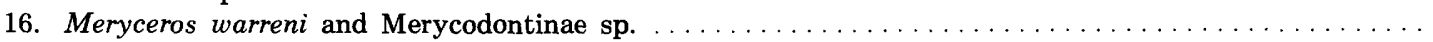

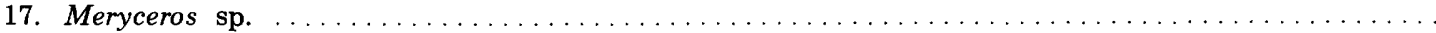

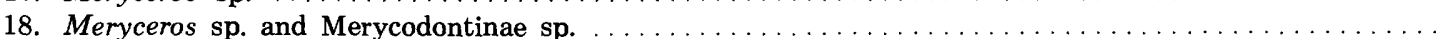

\section{TABLES}

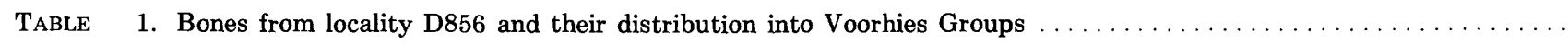

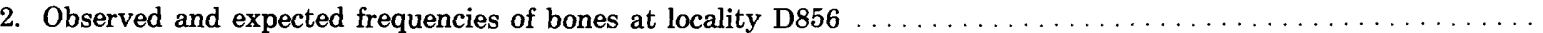

3. Bones from UALP locality 7498 and their distribution into Voorhies Groups $\ldots \ldots \ldots \ldots \ldots \ldots \ldots \ldots$

4. Observed and expected frequencies of bones for Michenia, Protolabis, and Equidae from UALP locality $7498 \ldots \ldots$

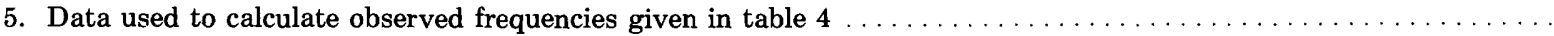

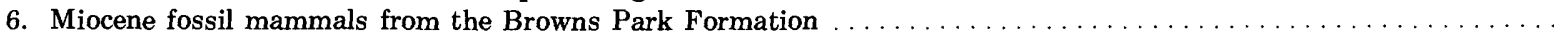

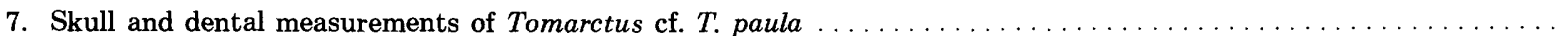

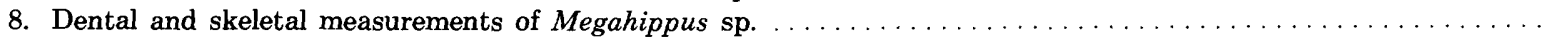

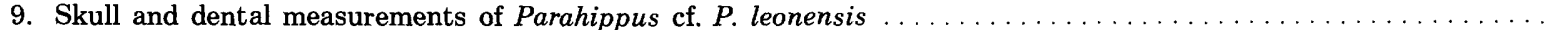

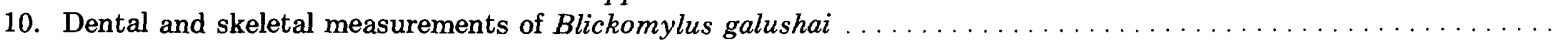

11. Skeletal measurements of cf. Protolabis sp.

12. Dental and skeletal measurements of Michenia sp.

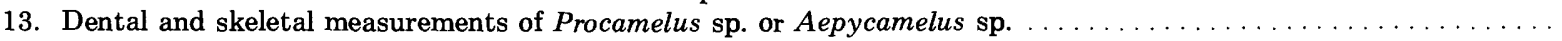

14. Skeletal measurements of Camelinae sp.

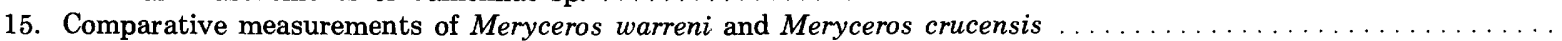

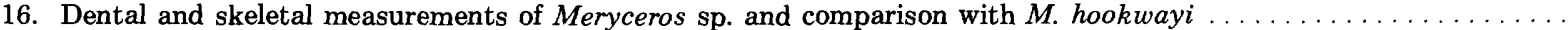

17. Fission-track age data for zircon microphenocrysts 


\title{
PALEONTOLOGY, TAPHONOMY, AND STRATIGRAPHY OF THE BROWNS PARK FORMATION (OLIGOCENE AND MIOCENE) NEAR MAYBELL, MOFFAT COUNTY, COLORADO
}

\author{
By James G. Honey and Glen A. Izett
}

\begin{abstract}
Fossils from four sites in the sparsely fossiliferous Browns Park Formation provide a new record of mammalian life in the middle Miocene in northwestern Colorado. The Browns Park fossils allow faunal dating of the upper part of the formation in the Maybell, Colo. area. Measurements of the orientation, relative abundance, and preservation of the fossil mammal bones at one locality indicate that the bones were not subjected to water currents before burial. The fracturing, destruction, and random orientation of the bones were probably caused mainly by intense carnivore activity; weathering may also have contributed to the bone destruction.

The Browns Park Formation crops out extensively in northwestern Colorado, and locally is more than $555 \mathrm{~m}$ thick near the town of Maybell. In the area we studied, which is southwest of Maybell, the formation is composed primarily of sandstone that contains a layer of conglomerate and conglomeratic sandstone about $9 \mathrm{~m}$ thick at its base. Pebbles and cobbles in the conglomerate were derived from adjacent topographic highs or from more distant sources. The overlying sandstone comprises three informal units. A white, crossbedded sandstone is the most widely exposed; the dip of its large-scale, highangle sets indicates that it was deposited by winds blowing from the southwest. A white, parallel-bedded sandstone lacks eolian crossstrata. A tan, parallel-bedded silty and clayey sandstone contains some mudstone and is probably of fluvial origin. The distribution of the basal conglomerate and the white, crossbedded sandstone suggests that the Browns Park Formation, at least in the Maybell area, was deposited in late Oligocene and Miocene time by the ancestral Yampa River flowing west from the northern Park Range in Colorado. Volcanic ash beds as thick as $3 \mathrm{~m}$ occur locally in the formation and range in age from $23.3 \pm 3.7$ m.y. near the base of the formation to $11.3 \pm$ $0.8 \mathrm{~m} . y$. near the highest preserved parts of the formation.

Despite its thickness and extent, the Browns Park Formation contains few fossils. In Colorado, only small collections from two localities had been reported before our study. In 1972, we discovered fossil mammals at four localities, comprising two local faunas, west of Maybell. The older local fauna, which we name the Cross Mountain local fauna (locality D857), is early to late Hemingfordian in age and contains the horse, Parahippus cf. P. leonensis, and the camel, Blickomylus galushai. The younger local fauna, which we name the Cedar Springs Draw local fauna (locs. D854, D855, D856), is late Barstovian to early Clarendonian in age. It contains the following fossil mammals:

the dog, Tomarctus cf. T. paula

the horse, Megahippus sp.

the camel, cf. Protolabis

the camel, Michenia sp.
\end{abstract}

the camel, Procamelus sp. or Aepycamelus sp. a camel, genus and species indeterminate an antilocaprid, Meryceros warreni an antilocaprid, Meryceros sp. an antilocaprid, genus and species indeterminate

The Cedar Springs Draw local fauna most closely resembles a largely undescribed late Barstovian to possibly early Clarendonian fauna from the Pojoaque Member of Galusha and Blick (1971) in the Tesuque Formation near Espanola, N. Mex. A volcanic ash in the Browns Park Formation that projects to the stratigraphic level of locality D855 has a fission-track age of $11.3 \pm 0.8 \mathrm{~m} . \mathrm{y}$. This age is latest Barstovian or early Clarendonian.

No generic similarity exists between the assemblages found in the Browns Park Formation at the Cross Mountain and Cedar Springs Draw local faunas of the Maybell area and Peterson's Douglas Mountain fauna of the Browns Park Formation farther northwest in Colorado; accordingly, comparisons among the faunas cannot be made. The Douglas Mountain fauna is difficult to date precisely owing to the small number of genera, but the fauna is considered to be of late Barstovian age.

\section{INTRODUCTION}

\section{BACKGROUND}

The Browns Park Formation was deposited in northwest Colorado, northeast Utah, and south-central Wyoming during latest Oligocene and Miocene time. The formation is as much as $600 \mathrm{~m}$ thick. Isotopic ages (Izett, 1975, p. 186) determined on minerals from volcanic ash beds interlayered in the formation range from about $26 \mathrm{~m} . \mathrm{y}$. near the base of the formation to about 9 m.y. in the highest preserved parts of the formation. The Oligocene and Miocene time boundary, as used herein, is $23.7 \mathrm{~m} . y$. based on a recent estimate made by Berggren and others (1985, p. 1409).

Fossils are rare in the Browns Park Formation, despite its extent and thickness. Previous discoveries of fossil vertebrates in the formation in Colorado have been reported from only two localities-one of unrecorded stratigraphic position and another from the 
middle part of the formation (Peterson, 1924, 1928). At both localites the fossil collections are small. In 1972, we discovered fossil vertebrates in the upper part of the formation at several localities west of Maybell, Colo. These fossils provide a significant record of mammalian life in northwest Colorado in medial Miocene time and allow faunal dating of the upper part of the formation in the Maybell area.

\section{PURPOSE}

The primary purpose of this paper is to describe the fossil mammals we collected from the Browns Park Formation between Maybell and Elk Springs, Colo. A second purpose is to compare the Browns Park fossil assemblages with other North American fossil mammal assemblages, thereby temporally placing the Browns Park fossils within the biochronological framework of North American land mammal ages. A third purpose is to propose a mechanism for burial (taphonomy) of the fossils. Brief descriptions of the rocks of the Browns Park Formation in the study area are included.

\section{LOCATION}

Most exposures of the Browns Park Formation studied, and all the fossil localities discussed in this report are between 40 and $63 \mathrm{~km}$ west of Craig, Colo. The area studied is in the northern half of the Citadel Plateau 15-minute quadrangle, and in the northeast part of the Elk Springs 15-minute quadrangle (fig. 1). The study area for the purpose of this report includes exposures of Browns Park Formation from Juniper Mountain on the east to locality D857 on the west, and from the town of Maybell on the north (located just outside the Citadel Plateau quadrangle), to the southernmost limit of Browns Park exposures in the Citadel Plateau quadrangle.

Access to the northern part of the study area is by U.S. Highway 40, which connects Craig, Maybell, and Elk Springs, Colo. The Deception Creek road, which connects Maybell with Meeker, Colo., extends along the eastern margin of the study area. The Cedar Springs Draw road, which runs south from U.S. Highway 40 and connects with the Deception Creek road, crosses the western part of the study area. Numerous unimproved dirt roads provide easy access to other points within the study area. Many exposures of Browns Park Formation were studied along U.S. Highway 40 between Craig and Elk Springs, Colo., a distance of about $69 \mathrm{~km}$.

\section{PREVIOUS INVESTIGATIONS}

The Browns Park Formation was named by Powell (1876) for outcrops of upper Cenozoic rocks exposed along the Green River in Browns Park in western Colorado and eastern Utah. Numerous geologists since Powell have studied the Browns Park Formation, and a thorough discussion of the older studies can be found in Buffler (1967, p. 9).

Several studies have been made of the Browns Park Formation in northwestern Colorado. Winkler (1970) described a white, sandstone unit near Maybell and concluded that it is of eolian origin. Izett and others (1970) determined an isotopic age of $24.8 \pm 0.8 \mathrm{~m} . \mathrm{y}$. for the lower part of the Browns Park Formation along the Little Snake River. Later, Izett (1975) reported a 9.1 \pm 1.0 m.y. isotopic age for the upper part of the formation west of the Little Snake River in sec. 21 , T. 9 N., R. 101 W., Moffat Co., Colo., and briefly discussed folding and faulting in the Browns Park Formation in northwest Colorado. Grutt and Whalen (1955), Bergin and Chisholm (1956), and Lewis (1977), discussed uranium mineralization in the Browns Park Formation in the Maybell-Lay area. Luft and Thoen (1981) measured a number of partial stratigraphic sections in the Browns Park Formation in Moffat County, Colo. Mapping by Sears (1924b), Hancock (1925), Bergin (1959), Dyni (1968), McKay (1974), McKay and Bergin (1974), Brownfield and Anderson (1979), Brownfield and Prost (1979), Rowley and others (1979), Reheis (1981), and Izett and others (1985) delineated the distribution of the Browns Park Formation in northwest Colorado.

Peterson (1924) described Browns Park fossils found near Sunbeam, Colo., and other fossils found a short distance farther west along Sand Wash. Later (1928) he described fossils collected from north of Douglas Mountain near Greystone, Colo. McGrew (1951, p. 55-56), Skinner (1968), and Frick and Taylor (1968) reexamined some of Peterson's Browns Park fossils; McGrew also reported on a small fauna from rocks near Saratoga, Wyo. that he assigned to the Browns Park Formation. An undescribed collection of Browns Park fossil mammals collected near Peterson's Douglas Mountain locality is in the Frick collection of the American Museum of Natural History.

\section{ABBREVIATIONS}

The following abbreviations are used in this report: Institutions

AMNH-Department of Vertebrate Paleontology, American Museum of Natural History 


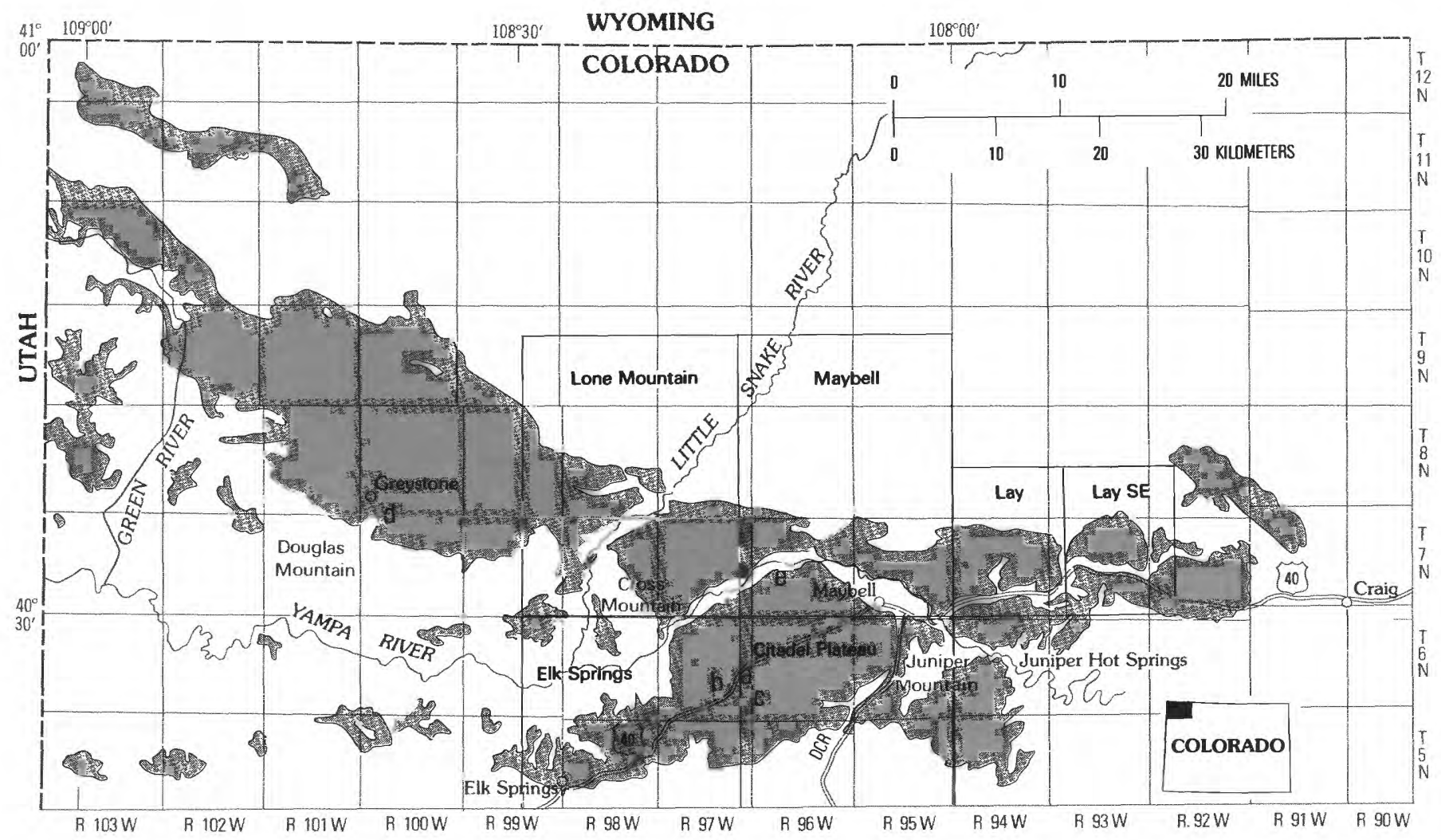

Figure 1.-Distribution of the Browns Park Formation (patterned area) in northwest Colorado and location of the Citadel Plateau, Elk Springs, Lone Mountain, and Maybell 15-minute quadrangles, and the Lay and Lay SE 71/2-minute quadrangles. Letters designate fossil localities: a, D854; b, D857; c, D855 and D856 of this report; d, Peterson's Weller Ranch locality near Douglas Mountain; e, Peterson's Sunbeam locality near Maybell. DCR, Deception Creek road. Distribution of Browns Park Formation modified from Tweto (1979).

BEG-University of Texas, Bureau of Economic Geology

LACM-CIT-formerly the California Institute of Technology; the collection is now at the Los Angeles County Museum

D854, D855, D856, D857-U.S. Geological Survey vertebrate locality numbers, Denver register

ESP-Field designation on some specimens in the AMNH

F:AM-Frick American Mammals, Department of Vertebrate Paleontology, American Museum of Natural History

FGS-Florida Geological Survey

UNSM-Nebraska State Museum

UALP-University of Arizona, Laboratory of Paleontology

UCMP-University of California, Museum of Paleontology, Berkeley

USNM-U.S. National Museum

Anatomy

$\mathrm{C}-$ canine $\mathrm{d}$-deciduous, as in $\mathrm{dI}$, deciduous incisor

I-incisor

L-left

$\mathrm{M}-$ molar

$\mathrm{P}$-premolar

R-right

Measurements and statistics

$\mathrm{AP}$-anteroposterior measurement

$\mathrm{EF}$-expected frequency

$\mathrm{n}$-sample size

$\mathrm{OF}$-observed frequency

O.R.-observed range

TR-transverse measurement

$\overline{\mathrm{X}}$-mean

m.y.-million years

\section{FIELDWORK AND ACKNOWLEDGMENTS}

This paper resulted from a study undertaken as part of a U.S. Geological Survey mapping program 
conducted by G. A. Izett, J. G. Honey, and M. E. Brownfield in the Citadel Plateau 15-minute quadrangle, Moffat County, Colo. Fossil and stratigraphic data were collected in the summers of 1972 and 1973 and during one short trip to the area in the summer of 1975 .

We appreciate advice and criticism concerning the mammalian paleontology given by $\mathrm{E}$. $\mathrm{H}$. Lindsay and G. G. Simpson (deceased) of the University of Arizona. L. L. Jacobs, L. H. Taylor, L. J. Flynn, and J. Baskin, all formerly of the University of Arizona, aided with quarrying at the University of Arizona's locality 7498 (discussed in this report). We owe special thanks to R. H. Tedford, B. E. Taylor, and M. F. Skinner of the American Museum of Natural History for allowing us to examine specimens in their care, for the loan of fossils, and for information concerning the fossils. We thank C. B. Schultz and L. G. Tanner of the University of Nebraska for showing us fossils in their care. M. E. Brownfield of the U.S. Geological Survey helped us collect fossils on several occasions.

\section{STRATIGRAPHY OF THE BROWNS PARK FORMATION}

\section{DISTRIBUTION}

The Browns Park Formation is extensively exposed in northwest Colorado and eastern Utah, and other sandstone outcrops in southern Wyoming have been correlated with the formation. The formation crops out in a continuous west-trending belt from an area just west of Craig, Colo., to its type area in Browns Park, which straddles the Utah-Colorado state line, a distance of about $136 \mathrm{~km}$ (Hansen, 1965, p. 115). In this belt the Browns Park Formation was deposited in a paleovalley cut on the Uinta Mountain arch, which was formed more than 26 m.y. ago (Izett, 1975, p. 189). Rocks referred to the Browns Park Formation are mapped on the north and south flanks of the Uinta Mountains, Utah, on the west flank of the Sierra Madre and Park Range in Colorado and Wyoming, on the White River Plateau in Colorado, and in the Poison Basin area, Wyoming (Izett, 1975 , p. 184-185).

\section{PHYSICAL CHARACTERISTICS AND OUTCROP PATTERN}

The sandstone of the Browns Park Formation erodes easily and is poorly exposed in the Maybell, Colo. area. The formation forms a blanketlike deposit of low relief in the northwest quarter of the Citadel Plateau quadrangle. The formation generally lies near the surface beneath a soil, but in many places it is covered by Pleistocene and Holocene eolian deposits, as south of Maybell, or by alluvial deposits, as along the Yampa River. At lower elevations, the formation is covered by grass and sage; at higher elevations, the formation is covered by shrubs and pinyon pine. The best exposures are in roadcuts, along arroyos, and occasionally, on steep slopes. The Browns Park forms some cliffs along the Yampa River between Juniper and Cross Mountains, and a small area of badlands on the west flank of Juniper Mountain. We examined all outcrops within the Citadel Plateau quadrangle, and numerous others outside the study area.

\section{GEOLOGIC SETTING AND CONTACT RELATIONS}

The study area includes the southern half of the westtrending depositional basin of the Browns Park Formation. The deepest part of the depositional basin is probably north of the study area, near Maybell, Colo., where more than $555 \mathrm{~m}$ of Browns Park have been drilled (S. J. Luft, written commun., 1980); the greatest thicknesses in the Citadel Plateau quadrangle, within the study area, are $510 \mathrm{~m}$ at the Texaco No. 1 State-K well in the NW1/4SE1/4 sec. 16, T. 6 N., R. 96 W., and $533 \mathrm{~m}$ at a core hole near this well. In the northeast corner of the Citadel Plateau quadrangle, the Browns Park paleovalley is split by the Juniper Mountain uplift, which exposes Precambrian and Paleozoic rocks surrounded by sandstone outcrops of the Browns Park Formation. To the west, the Browns Park Formation extends uninterrupted north and south of the Cross Mountain anticline.

The Browns Park Formation unconformably overlies all older formations and rests on rocks ranging in age from Precambrian to middle Eocene. Along the southern edge of the depositional basin, the Browns Park overlaps Mesozoic rocks, and farther west lies against the upturned edges of Cretaceous and Eocene strata. At the Texaco No. 1 State-K well, in the northwest part of the Citadel Plateau quadrangle, the Browns Park rests on Cretaceous Mancos Shale.

The Browns Park Formation within the study area is mostly flat lying. Along the southern edge of the Browns Park depositional basin, however, bedding dips from about $5^{\circ}$ to $30^{\circ}$ to the north, and along the northern edge of the depositional basin the rocks locally dip $30^{\circ}$ to the south (McKay and Bergin, 1974). PostBrowns Park faulting has considerably steepened the southerly dips along the northern edge of the basin (Sears, 1924a, p. 288).

A few small normal faults with throws generally less than $50 \mathrm{~m}$ locally cut the Browns Park in the Citadel 
Plateau quadrangle. Larger unseen faults may cut the formation in the study area, but because much of the formation is covered by surficial deposits their locations and throws are unknown.

\section{LITHOLOGY AND SEDIMENTARY STRUCTURES}

\section{BASAL CONGLOMERATE UNIT}

At surface exposures and in boreholes, the base of the Browns Park Formation commonly consists of a conglomerate or conglomeratic sandstone unit with clasts derived both from local bedrock and from distant source-rock areas. Just east of the Citadel Plateau quadrangle, near Juniper Hot Springs, Colo., the basal conglomerate consists of well-rounded pebbles and cobbles of Precambrian rocks composed of schist, gneiss, coarse- to fine-grained granite, white and reddish quartzite, and white and reddish vein quartz (Hancock, 1925 , p. 24). This may be the same conglomerate containing varicolored pebbles that was mentioned by Sears (1924a, p. 285) as being north of the Yampa River upstream from Juniper Canyon. South of Juniper Hot Springs, Reheis (1981) also reported igneous and metamorphic cobbles in the basal sandstone of the Browns Park. Presumably, all these pebbles and cobbles were derived from outcrops of Precambrian rocks in the Park Range east of Steamboat Springs, Colo. (Izett, 1975, p. 203). Along the south flank of Juniper Mountain in the northeast quarter of the Citadel Plateau quadrangle, the basal conglomerate unit contains quartzite boulders as much as $0.9 \mathrm{~m}$ in diameter of the Middle Proterozoic Uinta Mountain Group, perhaps locally derived from outcrops at Juniper Mountain. At surface exposures throughout much of the western part of the Citadel Plateau quadrangle (for example, in sec. 18, T. 5 N., R. 96 W.), the basal unit of the Browns Park consists chiefly of conglomerate and conglomeratic sandstone containing clasts of quartzite from the Middle Proterozoic Uinta Mountain Group, Paleozoic carbonate rocks, and chert, the last possibly of Paleozoic age. No igneous or high-grade metamorphic clasts were seen. However, in the Pan-American Petroleum No. 1 George Norvell well, in the NE1/4 sec. 3 , T. 5 N., R. 96 W., igneous rock fragments were recorded in the basal conglomeratic unit. North and northwest of the Citadel Plateau quadrangle, in the parts of the Maybell and Lone Mountain quadrangles east of the Little Snake River, the basal conglomerate unit also contains pebbles of mafic and felsic igneous and metamorphic rocks, quartzite, chert, and quartz (Sears, 1924b, p. 295; McKay, 1974; McKay and Bergin, 1974). West of the Little Snake River, in Colorado, the conglomerate consists only of red quartzite from the Uinta Mountain Group and some gray Paleozoic carbonate rock and chert. In the Elk Springs quadrangle west of the Citadel Plateau quadrangle, Dyni (1968) noted only carbonate and chert cobble conglomerate and red conglomeratic sandstone in the basal part of the Browns Park; these clasts were probably locally derived from outcrops on Cross and Juniper Mountains and the eastern Uinta Mountains. In the Park Range to the east, Crews $(1963$, p. 66$)$ and Buffler (1967, p. 24) reported granite and high-grade metamorphic rocks in the basal conglomerate of the Browns Park Formation.

\section{WHITE, CROSSBEDDED SANDSTONE UNIT}

White, crossbedded sandstone in the Browns Park Formation is widely distributed in northwest Colorado, and is locally well exposed in the Maybell area. In most areas, poor exposures make it impossible to determine the precise distribution of these rocks, but topographic expression and weathering characteristics suggest that the unit occurs at the surface over the entire area west of the Deception Creek road and north of T. 5 N. (except for a small area of Pleistocene and Holocene dunes in the northeast corner of this area). Rocks of this unit apparently blanket large areas to the north and west of the Citadel Plateau quadrangle in the Maybell, Lone Mountain, and Elk Springs quadrangles, and they extend eastward nearly to Craig, Colo.

This unit consists of gray to white quartzose sandstone that locally contains some interbedded volcanic ash beds and tuffaceous sandstone. The quartzose sandstone is fine to medium grained, well sorted, and the grains are subrounded to rounded and generally frosted. The sandstone contains more than 90 percent quartz grains, with black opaque mineral grains and dark lithic grains composing the remainder. Calcite locally cements this sandstone, which then forms resistant ledges. Beds of the white, crossbedded sandstone unit usually show high-angle cross-stratification, as in roadcuts along U.S. Highway 40 (fig. 2) and in cliffs along the Yampa River north of Maybell. Low-angle bounding surfaces commonly separate individual sets of high-angle crossstrata. Horizontal lamination is also present, as at fossil quarry D856. The white, crossbedded sandstones are generally friable, and in a few places have been a sediment source for active or recently stabilized dunes.

We examined crossbedding in the white, crossbedded sandstone unit to determine the transport direction of the sand grains. Crossbedding is best seen in roadcuts, and consists mainly of wedge-planar and tabular-planar (McKee, 1979, fig. 137) sets, which are medium to large scale, and straight to concave upward. These large-scale cross-strata were observed in roadcuts from Craig west 


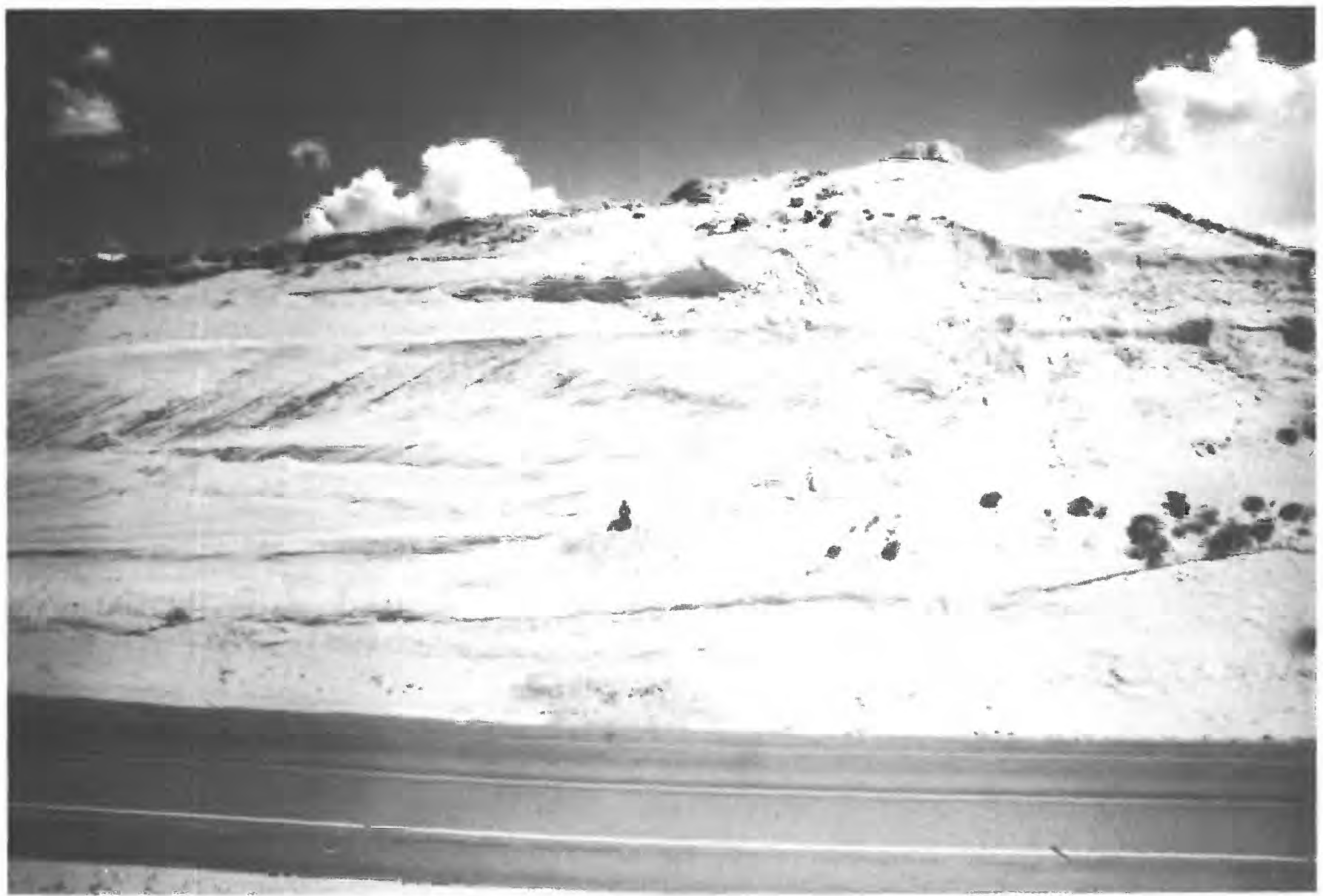

FIGURE 2.-View of roadcut exposure at locality D854 along U. S. Highway 40, at the west edge of the Citadel Plateau 15-minute quadrangle, Moffat County, Colo., showing large-scale, cross-stratified sandstone in the upper part of the Browns Park Formation. Person at center of photograph shows scale.

to Elk Springs, Colo. Dips recorded at these roadcuts generally range from $2^{\circ}$ to $34^{\circ}$, with most high-angle dips clustering between $24^{\circ}$ and $29^{\circ}$. Dips greater than $30^{\circ}$ in crossbedded sandstone of the Browns Park also were noted by Buffler (1967, p. 43) in the Elkhead region east of Craig, Colo.

The large-scale, high-angle, tabular- and wedge-planar sets in the Browns Park Formation are foresets formed on the slip faces of dunes. The large size and high angle of the individual sets, the low-angle bounding surfaces between some of the sets (McKee, 1979, p. 89), and the lack of coarse-grained channel-lag deposits suggest that the sandstone was deposited by eolian processes. A sample of medium-grained, well-sorted sandstone, with grains subrounded and frosted, was taken from foresets at roadcut locality D854. Most of the sandstone at D854 is not cemented by calcite, and the frosting of the grains probably was caused by abrasion during transport rather than by dissolution of grains by intrastratal solutions.
Winkler (1970, p. 48) also suggested an eolian origin for the crossbedded sandstone unit of the Browns Park in the Maybell area. Earlier, Bradley (1936, p. 182) thought that the Browns Park Formation west of Craig, Colo. and north of the Citadel Plateau quadrangle was in part eolian in origin. In addition, Chisholm (1963, p. 353) suggested that parts of the Browns Park Formation in northwestern Colorado and south-central Wyoming are eolian, and Buffler (1967, p. 60) suggested an eolian origin for his white sandstone facies of the Browns Park Formation in the Elkhead Mountains east of Craig, Colo.

The transport direction of the white, crossbedded sandstone was determined by 191 dip direction measurements taken on cross-strata along the 69-km stretch of highway between Craig and Elk Springs, Colo. Dip measurements taken from both high-and low-angle sets indicate an average transport direction of about N. $45^{\circ} \mathrm{E}$. (fig. $3 A$ ). Laminae dipping less than $15^{\circ}$ might have been deposited on the backs and sides of dunes, 
so a second average was calculated from the 135 dip measurements that were greater than $15^{\circ}$. The transport direction calculated was N. $47^{\circ} \mathrm{E}$., nearly the same as before (fig. 3B). Chisholm and others (1961, p. 84) obtained a south-to-north sediment transport direction for the Browns Park Formation, derived from more than 600 measurements made over a wide area. In the Elkhead region, Buffler (1967, fig. 10) obtained a bimodal distribution of dip maxima based on 250 bedding measurements in his white sandstone facies of the Browns Park Formation. His dip directions are also spread over a range of nearly $180^{\circ}$, but the mean of the measurements demonstrates a southwest to northeast transport direction, as in the area west of Craig, Colo.

Figure 3 is interpreted to indicate a unimodal wind regime. Both diagrams show the dominant northeast direction of sand transport; 87 percent of all the dips are within a $140^{\circ}$ arc in fig. $3 A$, and 93 percent of the high-angle dips (fig. $3 B$ ) are within the same arc. These dip direction distributions are similar to those reported for some barchan and dome dunes (Glennie, 1970, figs. 82 and 83; Ahlbrandt and Fryberger, 1980, p. 8; McKee, 1966, table IV). Parabolic dunes have a wide distribution $\left(180^{\circ}-270^{\circ}\right)$ of dip directions which may be strongly bimodal or trimodal (Ahlbrandt and Andrews, 1978, fig. 5; McKee and Bigarella, 1979, fig. 78; McKee, 1979, p. 195). The dip directions shown in figures $3 A$ and $3 B$ show no strong bimodality, but this may be partly because most of the dip readings were taken in an eastwest section along Highway 40 , where roadcuts gave the best exposures of crossbedding. Sample bias may thus have increased the number of measurements taken of high-angle strata dipping parallel to the highway and decreased the number of measurements taken on strata dipping normal to the highway. The spread of Browns Park dip directions is wider than that reported for transverse dunes (Ahlbrandt and Fryberger, 1980, fig. 6). The distribution of dip directions also does not correspond to expected distributions for linear (seif) dunes, which should have two clusters of dips opposite one another (McKee and Tibbitts, 1964; McKee, 1979), or dunes formed from scattered wind directions (star and reversing), in which a significant number of high-angle dips should be opposite the main northeast transport direction (McKee, 1966; McKee and Bigarella, 1979).

Stratigraphic sections were measured at fossil sites D855 and D856 in the white, crossbedded sandstone unit. Locality D855 is stratigraphically $15 \mathrm{~m}$ below locality D856. The following stratigraphic section shows the lithology at locality D855:
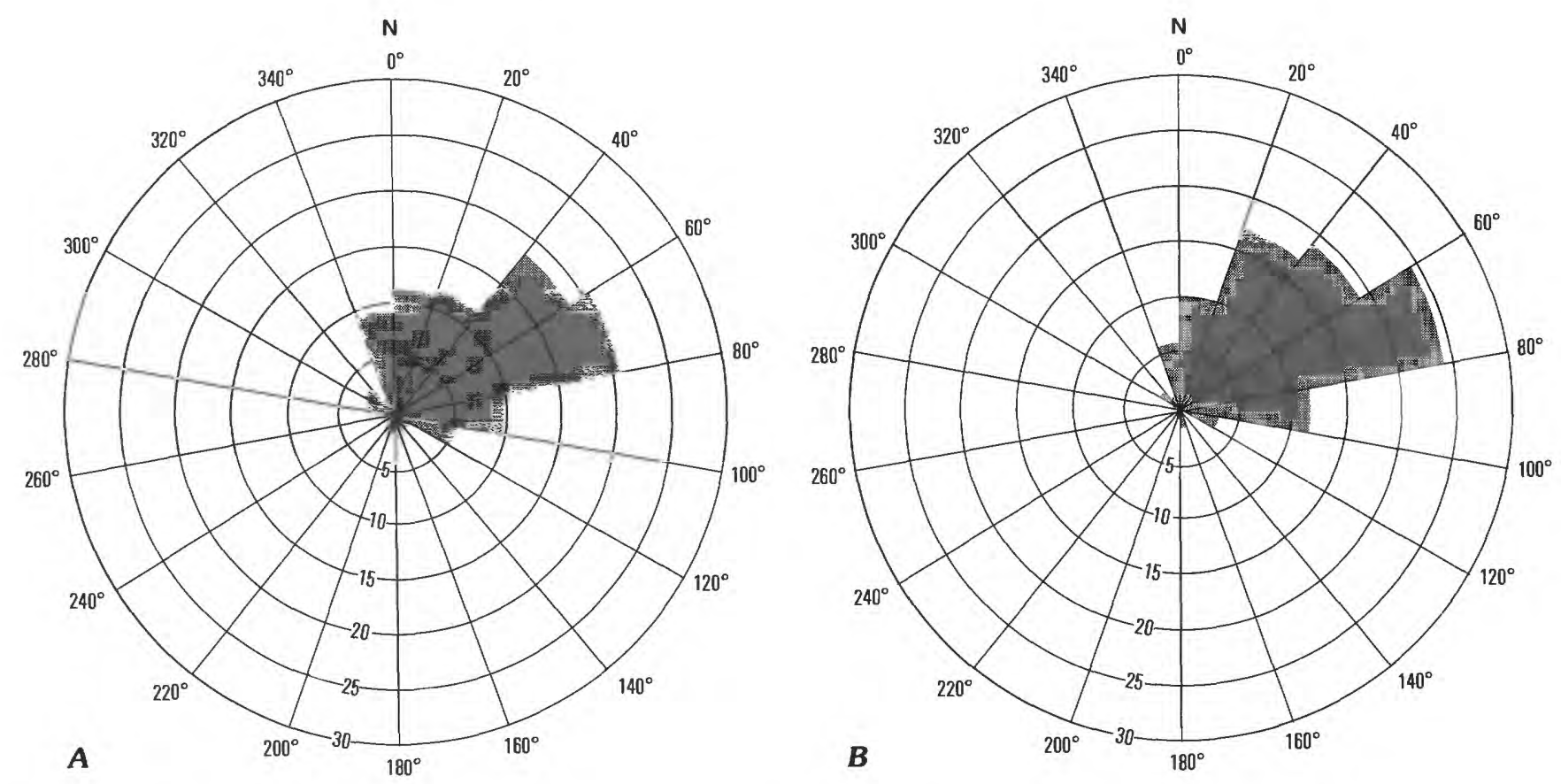

FIgURE 3.-Rose diagrams of dip direction measurements of the white, crossbedded sandstone unit of the Browns Park Formation in roadcuts along U.S. Highway 40 west of Craig, Colo. Concentric circles and associated values represent percent of total number of observations. Numbers on periphery of each circle show dip direction. $A$, plot of 191 dip directions. $B$, plot of 135 dip directions (dips equal to or greater than $15 \%$. 
Section of the Browns Park Formation (top to bottom) exposed on northwest slope of a ridge in the NE1/4 sec. $36, T .6$ N., R. $97 \mathrm{~W}$., Moffat County, Colorado

Sandstone, quartzose, in part tuffaceous, very fine Thickness
Meters Feet grained to fine-grained, well-sorted, grains frosted; less than 1 percent dark lithic fragments. Alternating resistant and nonresistant layers about 6.4 cm thick; resistant layers calcareous. Vertebrate fossils found beneath a thin calcareous mudstone

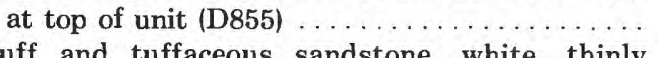

Tuff and tuffaceous sandstone, white, thinly laminated, highly calcareous .............

Volcanic ash, blue-gray, vitric, very finely laminated

Sandstone and tuffaceous sandstone, very fine grained to fine-grained, highly calcareous; individual laminae 0.10-0.51 cm thick; more tuffaceous parts weather as resistant white laminae

Tuffaceous sandstone and tuff, gray at bottom of unit and white at top; no calcite cement; individual laminae $0.10-0.51 \mathrm{~cm}$ thick

Quartzose sandstone, tan, very fine grained, moderately well sorted; individual laminae $0.10-0.30 \mathrm{~cm}$ thick

Bottom of exposure . . . . . . . . . . . . Total thickness of section
Sandstone, greenish-gray, quartzose, fine-grained, well-sorted, less than 10 percent dark lithic fragments; grains subrounded to rounded, calcite cemented; unit massive; root casts common near

top . . . . . . . . . . . . . . . . . . . .

Base of excavation

Total thickness of section

$\underline{\underline{1.02}}$

The sandstone at locality D856 is probably of eolian origin. Some evidence is inconclusive: the frosting of the grains, for example, could result from either eolian transport or chemical solution. But most of the evidence suggests eolian origin: horizontal sand laminae associated with eolian deposition have been described from modern interdune, sheet sand, and wadi-fill deposits (Ahlbrandt and Fryberger, 1981, and references therein), and from ancient eolian deposits (Adams and Patton, 1979; McKee, 1979, and references therein). No silt or clay interbeds were seen at D856, and visual examination suggests that the sand is nearly as well sorted as in nearby Browns Park dune deposits. Glennie (1970, p. 39 and 106) mentioned and illustrated the occurrence of horizontally laminated, well-sorted sands in both desert wadis and sheet sands. Ahlbrandt and Fryberger (1981, fig. 7) interpreted some horizontally laminated sandstones of the Browns Park Formation near Maybell, Colo., as interdune deposits. Horizontal laminae could have been present in the other layers at locality D856, but may have been destroyed due to bioturbation by plant roots.

Horizontal stratification also occurs in lacustrine deposition, but no lacustrine fossils such as freshwater mollusks or fish were found in the rocks at locality D856. Also, no load structures, mudcracks, or any other features that might have formed in a lacustrine environment were found.

Horizontal stratification may also occur locally due to flood deposition, and may constitute the bulk of a flood deposit (McKee and others, 1967, p. 829). In the Bijou Creek, Colo., flood deposit studied by McKee and others (1967), the sediment was fine- to coarse-grained quartzose sand. In contrast to the sandstone at D856, the sorting usually was only fair; rarely was the sorting good. Williams (1971, p. 35) however, noted that upper flow regime plane beds were the best sorted in the flood deposit he studied. The D856 locality lacks the armored mud balls noted at Bijou Creek. The fine-grained sandstone at D856 would not suggest high water velocities; however, the grain size in flood deposits partially depends on the size of the material available for transport (McKee and others, 1967; Williams, 1971). If the layers at locality D856 are flood deposits, it might be supposed that the fossils represent the larger material transported during the flood. However, the fossils 0.42 show no evidence of transport in their orientation or grains subrounded and frosted, calcite cemented; thinly laminated; root casts common; fossil horizon 
abundance. The field evidence then, suggests that the sandstone at locality D856 is of eolian rather than of fluvial or lacustrine origin.

\section{WHITE, PARALLEL-BEDDED SANDSTONE UNIT}

White, parallel-bedded sandstone crops out west of the Deception Creek road in secs. 1, 2, and 11, T. 5 N., R. 96 W., south of Juniper Mountain, and along the north bank of the Yampa River just north of Juniper Mountain. Rocks at these exposures lack the high-angle cross-stratification of the white, crossbedded unit. The parallel-bedded unit is generally highly calcareous, resistant, and laterally continuous. In the study area, white, parallel-bedded sandstone is typically exposed near the base of the Browns Park Formation, and is older than the eolian crossbedded sandstone. South of Juniper Mountain, for example, the Browns Park is only $152 \mathrm{~m}$ thick in the Moore and Gilmore No. 1 Seeley well drilled in the NE1/4SE1/4SE1/4, sec. 2, T. 5 N., R. $95 \mathrm{~W}$., and rocks of the white, parallel-bedded unit are exposed near this location. Along the Deception Creek road, white, parallel-bedded sandstone directly overlies Mancos Shale of Cretaceous age. In contrast, rocks of the white, crossbedded unit occur at the surface at the Texaco No. 1 State-K well in the NW1/4SE1/4 sec. 16, T. 6 N., R. 96 W., and are underlain by about $510 \mathrm{~m}$ of Browns Park Formation.

\section{TAN SANDSTONE UNIT}

Rocks of the tan sandstone unit of the Browns Park crop out on Cedar Knob in secs. 6 and 7, T. 5 N., R. 96 $\mathrm{W}$. These rocks contain more mudstone than do rocks of the white, crossbedded sandstone unit; bedding is generally parallel, and no large-scale, high-angle crossstratification is present. The measured section that follows gives the general characteristics of rocks of this unit.

Section of the Browns Park Formation (top to bottom) on south side of Cedar Knob in the NE1/4 sec. 7, T. 5 N., R. 96 W., Moffat County, Colorado

Sandstone, tan, fine-grained, friable; forms slope; fossil

Sandstone, grayish-white, calcareous, fine to mediumgrained, poorly sorted with dark lithic fragments, thick to massive bedded; forms top of resistant ledge

Thickness Meters Feet 2.8 9.3

Mudstone, grayish-white, tufface

Volcanic ash, white, vitric, thinly laminated near base, becoming calcareous near top; forms bottom of resistant ledge
Mudstone, pinkish-tan, calcareous and indurated; contains root casts

Sandstone, pinkish-tan, friable; discontinuous calcareous mudstone ledge near base of unit; $0.4 \mathrm{~m}$ resistant but discontinuous calcareous sandstone ledge $1.5 \mathrm{~m}$ below top of unit Sandstone, greenish-gray, fine- to coarse-grained, poorly sorted, calcareous; contains coarse, subangular lithic fragments; a few root casts present; forms resistant ledge

Sandstone, pinkish-tan, medium-grained, friable; top $0.61 \mathrm{~m}$ calcareous and thinly laminated

Calcareous mudstone, white at base, becoming darker gray with medium-grained sandstone in upper 15.3 $\mathrm{cm}$; forms resistant ledge

Volcanic ash, blue-gray, and tuffaceous sandstone; thinly laminated near base; calcareous near top of unit

Sandstone with calcareous interbeds, fine-grained; forms slope except for more resistant interbedded

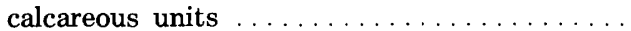

Calcareous mudstone, grayish-tan . . . . . . . .

Sandstone, tan, medium-grained, moderately well sorted, subangular, unconsolidated; forms slope at base of hill

Total thickness of section

$\begin{array}{rr}1.1 & 3.7 \\ 2.4 & 7.9 \\ 3.1 & 10.0 \\ & \\ \underline{1.8} & \underline{\underline{23.0}} \\ \underline{\underline{74.8}}\end{array}$

Surficial deposits hide the exact stratigraphic relationships between the tan sandstone unit and the white, crossbedded sandstone unit. On Cedar Knob, only rocks of the tan sandstone unit are exposed, and this unit was not recognized elsewhere in the study area. The section measured on Cedar Knob is topographically from about $46 \mathrm{~m}$ to more than $61 \mathrm{~m}$ above locality D856, and bedding-plane attitudes were nearly horizontal. Cedar Knob may have been faulted up relative to the rest of the Browns Park Formation, as suggested by the gross lithologic similarity of the rocks at Cedar Knob to the rocks exposed nearly $48 \mathrm{~km}$ farther west at the northern base of Douglas Mountain. There, Peterson's (1928) fossil locality lies stratigraphically lower in the Browns Park Formation than fossil locality D856. Near Douglas Mountain, Peterson (1928, p. 93) measured $224 \mathrm{~m}$ from the base of the Browns Park Formation to the fossil horizon; the total thickness of the Browns Park Formation at locality D856 is unknown, but it is $533 \mathrm{~m}$ thick north of D856, in SE1/4 sec. 16, T. 6 N., R. 96 W. If, however, the rocks at Cedar Knob have not been faulted up relative to the rest of the formation, then the tan sandstone unit would be the highest preserved part of the Browns Park Formation. This relationship corresponds to the stratigraphic relations noted by Buffler $(1967$, p. 46) in the Elkhead region east of Craig, Colo., where he described a Miocene brown sandstone facies overlying an eolian crossbedded white sandstone facies. Buffler assigned an Arikareean to Hemingfordian age to the white sandstone facies, which would make it older than the white, crossbedded unit in the 
Maybell area. Buffler's age assignment however, was based only on lithologic similarity of the Miocene rocks of the Steamboat Springs, Colo., area with the Arikareean to Hemingfordian Split Rock Formation (Love, 1961) in central Wyoming.

\section{VOLCANIC ASH}

The Browns Park contains lenticular beds of vitric, friable volcanic ash from the base to the highest preserved parts of the formation. The thickness of these beds ranges from several centimeters to several meters. Many of the ash beds are nearly pure in that they contain a high proportion of glass shards, and are not contaminated by sediments. Some of the ash beds are indurated and blocky, probably caused by incipient alteration of the glass shards.

In the eastern part of the Citadel Plateau quadrangle (SW1/4 sec. 10 and SE1/4 sec. 14, T. 5 N., R. 95 W.) one or more white, biotite-bearing ash beds, about $15 \mathrm{~cm}$ thick, occur about $9 \mathrm{~m}$ above the base of the Browns Park Formation. A gray ash bed $15 \mathrm{~cm}$ thick occurs 3.0-3.7 $\mathrm{m}$ below this white ash. In sec. 10, T. 5 N., R. $95 \mathrm{~W}$., three white ash beds occur in a 1.4-m-thick interval directly overlying a gray ash. Farther west, in the W1/2 sec. 9 and NE1/4 sec. 10, T. 5 N., R. 96 W., a biotite-bearing white ash occurs about $9 \mathrm{~m}$ above the base of the Browns Park, but gray ash beds are apparently missing. In sec. 10, this white ash was dated at $23.3 \pm 3.7$ m.y. (Izett, 1975, p. 187, table 1), and may correlate with a white, biotitic ash about $30 \mathrm{~m}$ above the base of the Browns Park at the Little Snake River, dated at $24.8 \pm 0.08 \mathrm{~m} . y$. (Izett and others, 1970, p. $\mathrm{C} 150-\mathrm{C} 152$ ).

Ash beds that are stratigraphically higher in the Browns Park Formation include two gray volcanic ash beds on a hill in the NW1/4SE1/4 sec. $25, T .6$ N., R. $97 \mathrm{~W}$. These ash beds are in the upper part of the white, crossbedded sandstone unit, and the higher of the two is the same elevation as the D855 quarry. The upper ash is $23 \mathrm{~m}$ stratigraphically above the lower ash, and has been dated at $11.3 \pm 0.8 \mathrm{~m}$.y. (see Isotopic Age). Two bluish-gray ash beds, presumably of medial Miocene age, occur on the south side of Cedar Knob. These two ashes lie in the tan sandstone unit of the Browns Park Formation, and are about $10 \mathrm{~m}$ stratigraphically apart. Izett (1975) reported other volcanic ash beds within the Browns Park Formation elsewhere in northwestern Colorado.

\section{THICKNESS OF THE BROWNS PARK FORMATION}

The Browns Park Formation thickens from zero along the southern edge of the Browns Park depositional trough south of Cedar Knob to more than $555 \mathrm{~m}$ near Maybell (S. J. Luft, written comm., 1980). Similar maximum thicknesses were recorded at drill holes located west of the Deception Creek road and north of T. $5 \mathrm{~N}$. South of Juniper Mountain, however, the formation is locally considerably thinner-153 $\mathrm{m}$ thick at the Moore and Gilmore No. 1 Seeley well in the NE1/4SE1/4SE1/4 sec. 2 , T. 5 N., R. 95 W. In the Elk Springs quadrangle, Dyni (1968) recorded a maximum thickness of about $457 \mathrm{~m}$ east of Cross Mountain. In the Maybell quadrangle, McKay and Bergin (1974) recorded a maximum thickness of $488 \mathrm{~m}$. In the Lone Mountain quadrangle, McKay (1974) recorded a similar thickness. To the east of the study area, the maximum thickness of the Browns Park Formation is $259 \mathrm{~m}$ in the Lay quadrangle (Brownfield and Prost, 1979) and $274 \mathrm{~m}$ in the Lay SE quadrangle (Brownfield and Anderson, 1979). Buffler (1967, p. 38) recorded a maximum thickness of $671 \mathrm{~m}$ at Sand Mountain in the Elkhead region east of Craig, Colo. In the type area of the formation in Browns Park, the total thickness of the formation is unknown, owing to lack of subsurface information, but Hansen (1965, p. 127) obtained a partial thickness of $250 \mathrm{~m}$ for the formation by measuring surface exposures in the type area, and S. J. Luft (written commun., 1980) reported at least $364 \mathrm{~m}$ in the Vermillion Mesa $7 \frac{1}{1} 2$-minute quadrangle, Moffat County, Colo.

In the Citadel Plateau quadrangle, a maximum thickness of about $9 \mathrm{~m}$ was measured for the basal conglomerate at surface exposures. In the subsurface, the basal conglomeratic sandstone ranges from less than $6.1 \mathrm{~m}$ in the Utah Southern Kingston No. 2 well, in the center of the NW1/4NW1/4 sec. 11 , T. 5 N., R. 96 W., to at least $27.4 \mathrm{~m}$ in the Moore and Gilmore No. 1 Seeley well.

In the Elk Springs quadrangle, Dyni (1968) recorded an average thickness of $12.2-27.4 \mathrm{~m}$ for the basal conglomerate unit and a maximum thickness of $41.1 \mathrm{~m}$. In the Maybell quadrangle, McKay and Bergin (1974) reported a thickness for the basal conglomeratic sandstone of only $0.3-0.9 \mathrm{~m}$, yet farther west, in the Lone Mountain quadrangle, McKay (1974) reported a thickness of as much as $91 \mathrm{~m}$ for the basal conglomerate. In the Elkhead region to the east, Buffler (1967, p. 20) reported a similar range of thicknesses -0 to $91 \mathrm{~m}$.

The total thicknesses for the white, crossbedded sandstone unit, the white, parallel-bedded unit, and the tan sandstone unit were not determined in the study area. About $88 \mathrm{~m}$ of sandstone separates the base of the eolian sandstone at D854 from the top of the hill at quarry D856, which represents a minimum thickness for the crossbedded sandstone unit-the maximum thickness is probably much greater. At the Texaco No. 1 State-L well, just north of the study area, frosted 
quartz grains were present in the Browns Park sandstone down to a depth of at least $168 \mathrm{~m}$. Winkler (1970, p. 50) reported a thickness of about $122 \mathrm{~m}$ for the white, crossbedded unit in the Maybell area, but the method of calculating this thickness was not given. Buffler (1967, p. 41) measured more than $183 \mathrm{~m}$ of sandstone containing large-scale cross-stratification in his white sandstone facies in the Elkhead region.

On Cedar Knob in the Citadel Plateau quadrangle, about $23 \mathrm{~m}$ of tan sandstone unit is exposed, but the total thickness of that unit is probably greater. The thickness of the white, parallel-bedded unit was not determined.

\section{SOURCE AREA AND MODE OF DEPOSITION}

As mentioned, the basal conglomerate in the study area is derived from both local and distant sources. Field evidence for derivation of the cobbles in the conglomerate unit from nearby topographic highs is found on the south flank of Juniper Mountain in the NE1/4NE1/4 sec. 34, T. 6 N., R. 95 W., where the base of the Browns Park consists of a fine-grained sandstone containing scattered quartzite boulders of the Middle Proterozoic Uinta Mountain Group. Some of these boulders are $0.9 \mathrm{~m}$ in diameter. About $3.2 \mathrm{~km}$ southeast of this locality, at the Moore and Gilmore No. 1 Seeley well, at least $27 \mathrm{~m}$ of slightly conglomeratic sandstone (but no distinct conglomerate beds) was penetrated at the base of the Browns Park. This conglomeratic sandstone may have been derived from nearby Precambrian and Paleozoic rocks at Juniper Mountain.

Outcrops of Precambrian and Paleozoic rocks at Cross Mountain, Colo., probably contributed more to the basal conglomerate in the Citadel Plateau quadrangle than did similar outcrops at Juniper Mountain. Quartzite pebbles and cobbles of the Uinta Mountain Group are larger and more numerous in the basal conglomerate in the western part of the Citadel Plateau quadrangle, indicating a western source for some of this material. As mentioned, the total thickness of the basal conglomerate increases to the west in the Elk Springs quadrangle, suggesting that the basal conglomerate extended east and south from near Cross Mountain, and formed an alluvial apron of gradually decreasing thickness. The eastern extent of this alluvial apron is unknown, but it probably terminated near Deception Creek, west of the barrier formed by Juniper Mountain. Igneous rock pebbles in the basal conglomerate in Pan American Petroleum No. 1 Norvell well, and the mafic and felsic igneous and high-grade metamorphic pebbles of the basal conglomerate in the Maybell and Lone Mountain quadrangles east of the Little Snake River, were derived from source areas other than the Uinta
Mountains. These pebbles were possibly derived from the northern Park Range, as suggested by Izett (1975, p. 203) for the pebbles at Juniper Hot Springs. This derivation suggests that a west-flowing river-the ancestral Yampa-originated in the Park Range and flowed at least as far west as the Little Snake River during late Oligocene and early Miocene time. The course of the ancestral Yampa west of the Lone Mountain quadrangle is uncertain, as only quartzite, chert, and limestone cobbles in the basal Browns Park conglomeratic unit have been reported west of the Little Snake River (Sears, 1924b; McKay, 1974).

It is possible that the extensive eolian dunes in the Maybell area were formed from sand deposited along the course of the ancestral Yampa River. Allen (1965, p. 162-163) noted that migrating dunes sometimes form belts along the course of a river and are formed from sand winnowed from channel deposits at times of low water. A sand belt is present today in northeast Colorado along the south side of the South Platte River, and its distribution can be seen on the Geologic Map of Colorado (Tweto, 1979). The white, eolian crossbedded sandstone of the Browns Park Formation is widespread between Craig and Cross Mountain, Colo., and may reflect the course of the ancestral Yampa. If so, then in Miocene time the Yampa was a west-flowing stream probably following a course similar to its modern course between Craig and Cross Mountain. Bergin and Chisholm (1965, p. 195) had previously suggested a possible Sierra Madre-Park Range origin for their nontuffaceous sandstone facies of the Browns Park in the Maybell area. Such a source would also indicate westward-flowing streams or a river from the Park Range in Miocene time. Southwest of Cross Mountain, eolian sandstone is also present at Elk Springs, Colo., and (S. J. Luft, written commun., 1980) eolian sandstone also occurs at places northwest of Cross Mountain to the Utah state line. What the relation of these occurrences of eolian sandstone are to the inferred location of the ancestral Yampa is unknown.

\section{VERTEBRATE TAPHONOMY OF THE BROWNS PARK FORMATION}

\section{INTRODUCTION}

The orientation of the fossil bones at locality D856, the relative abundance of the different bone elements, and the character of bone preservation indicates how the bones were buried and what may have altered them after burial. As stated by Voorhies $(1969$, p. 2), taphonomy " $* * *$ is concerned with the factors intervening between a living fauna and the fossilization of a 
fraction of it. It deals mainly with the post-mortem history of animal remains (especially their decay, transportation, and burial) but also with cause of death."

The bones at locality D856 are mainly disarticulated, fragmentary, and dispersed. Carnivore utilization of a limited food resource, with associated trampling and kicking, best accounts for the observed bone fragmentation and dispersal. Weathering at the time of deposition probably accounts for some of the surface texture observed on the bones. The bones do not appear to have been reworked or transported by water, based on bone abundance and orientation data, including comparisons with a site in Arizona where the bones apparently were deposited by running water. Other possible influences, including sediment compaction, tectonism, and calcite deposition, do not account for the condition and distribution of the bones at locality D856.

\section{ON THE ROLE OF WATER AS A DISPERSIVE AGENT}

\section{BONE ORIENTATIONS}

Orientation data help determine whether bones were aligned in a current of water. Stream-table experiments by Voorhies $(1969$, p. 66$)$ showed that water-transported bones tend to be deposited parallel or transverse to current direction, depending on the type of bone and the depth of water; long bones tend to align transverse to the current in shallow water and parallel to the current in deeper water. Bones that parallel the current direction have their large ends downstream. In his analysis of the Verdigre quarry flood deposit in Nebraska, Voorhies (1969, fig. 9) found two mutually perpendicular directions for the bones which he interpreted as parallel and transverse to the current direction. In the Verdigre deposit, many bones had high angles of plunge, which Voorhies attributed to two factors: rapid burial in a high-energy flood situation, with little chance to return to the more stable horizontal position; imbrication in an upstream direction. At locality D856, the orientation of fossil vertebrate bones was determined in the field and later plotted on a stereonet (fig. $4 A$ ). Most bones lie in a horizontal plane, and are represented on the stereo diagram by two points 180 degrees removed from each other on the periphery. A rose diagram constructed from the same data (fig. $4 B$ ), showing only the azimuth of each bone, indicates no strong preferred orientations that might be interpreted as parallel and transverse to a current. Most of the bones are near horizontal, and
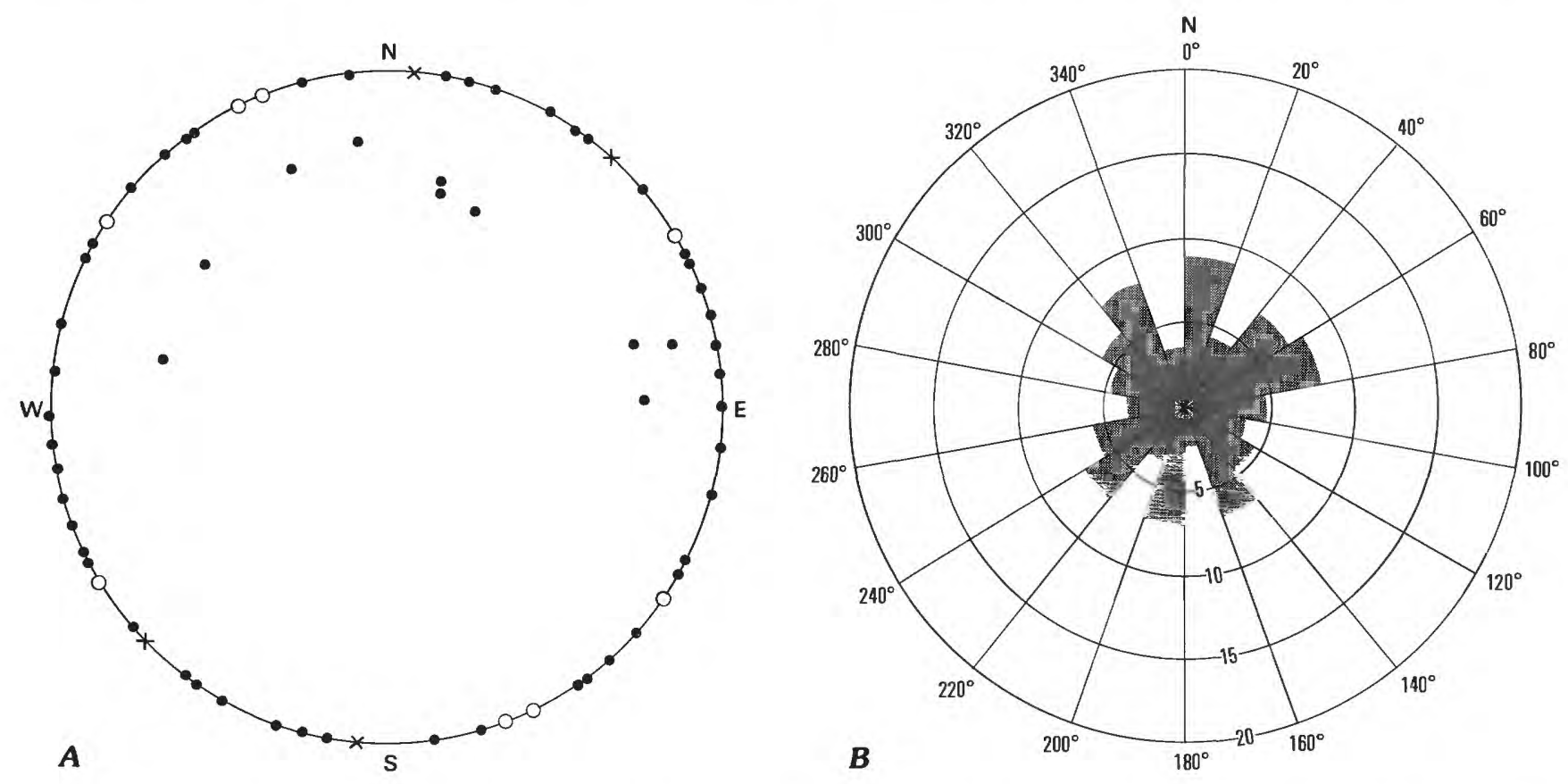

Figure 4.-Orientation of fossil mammalian bones from the Browns Park Formation at locality D856 in the Citadel Plateau 15-minute quadrangle, Moffat County, Colo. A, Stereographic projection; poles of bones plotted on the lower surface of a stereonet; filled circle, one pole; open circle, two poles at same position; cross, three poles at same position. Observations at periphery of diagram indicate horizontal bones. $B$, Rose diagram showing azimuths of bones; observed asymmetry results from bones with plunge greater than 0 degrees; values for these bones plot only in one quadrant. Concentric circles and associated values represent percent of total number of observations. 
TABLE 1.-Bones from locality D856 and their distribution into Voorhies Groups

\begin{tabular}{|l|l|l|c|c|}
\hline \multicolumn{1}{|c|}{ Group I } & Group I/II & Group II & Group II/III & Group III \\
\hline 6 vertebrae & 27 phalanges & 6 distal humeri & 5 rami and partial rami & 1 sku11 \\
4 ribs & 4 calcanea & 7 proximal radi & 1 fragment skul1 \\
& 6 astragali & 7 distal radi i-ulnae & & 1 mandible \\
& 7 podials & 2 distal tibiae & & \\
& 1 scapula & 5 distal metapodials & & \\
& & 1 proximal metapodials & & \\
& & & & \\
\end{tabular}

none plunge at high angles. At the time of excavation, large ends were distinguished from small ends on only eight bones. Seven of these bones plunge northeast, with the large ends oriented northeast on five and southwest on two; the eighth bone plunges northwest, with the small end pointed northwest. These few bones indicate a slightly greater tendency for the large ends to be pointed north. The northwest and northeast plunge of the bones suggests that the upstream direction would be to the north if the bones were imbricated. However, only three of the eight bones have the large ends pointed south, which would be in the downstream direction. This suggests that the bones at locality D856 were not acted upon by a current of water.

\section{RELATIVE ABUNDANCE OF BONES}

The relative abundance of the different skeletal elements at locality D856 (table 1) provides further information on whether the bones were influenced by water currents. The relative abundances are determined by listing each skeletal element and the number of times it occurs. The bones listed in table 1 are divided into five Voorhies Groups (Behrensmeyer 1975, p. 484) according to their susceptibility to water transport. Voorhies (1969, p. 16) noted that ribs, vertebrae, sacra, and sterna (Group 1) tend to be easily removed in a current; others, principally long bones, (Group II) are removed gradually. Rami, skulls, and mandibles (Group II/III, III) form a lag deposit. All three groups are present at locality D856. Group I is underrepresented owing to collecting bias. The observed and expected frequencies of selected skeletal elements are given in table 2. The observed frequencies of most of the long bones are only slightly greater than would be expected if these bones were not transported. On the other hand, the observed frequency of metapodials is slightly less than expected. The observed frequencies of proximal phalanges, calcanea, and astragali are very near the expected values if they had not been transported, whereas the observed frequencies of skulls and mandibles are slightly less than expected. The sample is small, which has probably caused some slight differences in observed frequencies. For example, the observed frequencies of calcanea and astragali should be the same, but they are slightly different. Similarly, there are 22 complete and partial proximal phalanges preserved, whereas only 5 medial phalanges and no distal phalanges were recognized. The larger size of the proximal phalanges probably has resulted in their better preservation and consequent recognition.

Behrensmeyer (1975, fig. 5) showed that a bone assemblage composed of Groups I, II, and III is an undisturbed concentration. The relative numbers of bones in each group, though, is important for interpretation. At locality D856, the members of Group II are the most abundant, but not disproportionately so. The observed

TABLE 2.-Observed and expected frequencies of bones from locality D856

[The number of rami is given the frequency of 1.0; the number of identifiable parts of other bones is then divided by the number of rami. For example, in a complete skeleton there are 1 skull, 2 distal humeri, and 8 proximal phalanges per 2 rami, resulting in expected frequencies of $0.5,1.0$, and 4.0. There were excavated 2 skulls, 6 distal humeri, and 22 proximal phalanges per 5 rami, resulting in observed frequencies of $0.4,1.2$, and 4.4 ]

\begin{tabular}{|c|c|c|}
\hline Elements & $\begin{array}{l}\text { Observed } \\
\text { frequencies }\end{array}$ & $\begin{array}{l}\text { Expected } \\
\text { frequencies }\end{array}$ \\
\hline 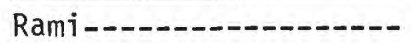 & 1.0 & 1.0 \\
\hline Skul 1s-1s- & 0.4 & 0.5 \\
\hline Mandibles-_-_- & 0.2 & 0.5 \\
\hline Distal humeri-...-.-.- & 1.2 & 1.0 \\
\hline Proximal radii-ulnae-- & 1.4 & 1.0 \\
\hline Distal radi i-ulnae-..-- & 1.4 & 1.0 \\
\hline Distal tibiae--------- & 0.4 & 1.0 \\
\hline Proximal metapodials-- & 1.4 & 2.0 \\
\hline Distal metapodials...- & 1.4 & 2.0 \\
\hline Proximal phalanges---- & 4.4 & 4.0 \\
\hline Astragali-_. & 1.2 & 1.0 \\
\hline Calcanea-- & 0.8 & 1.0 \\
\hline
\end{tabular}



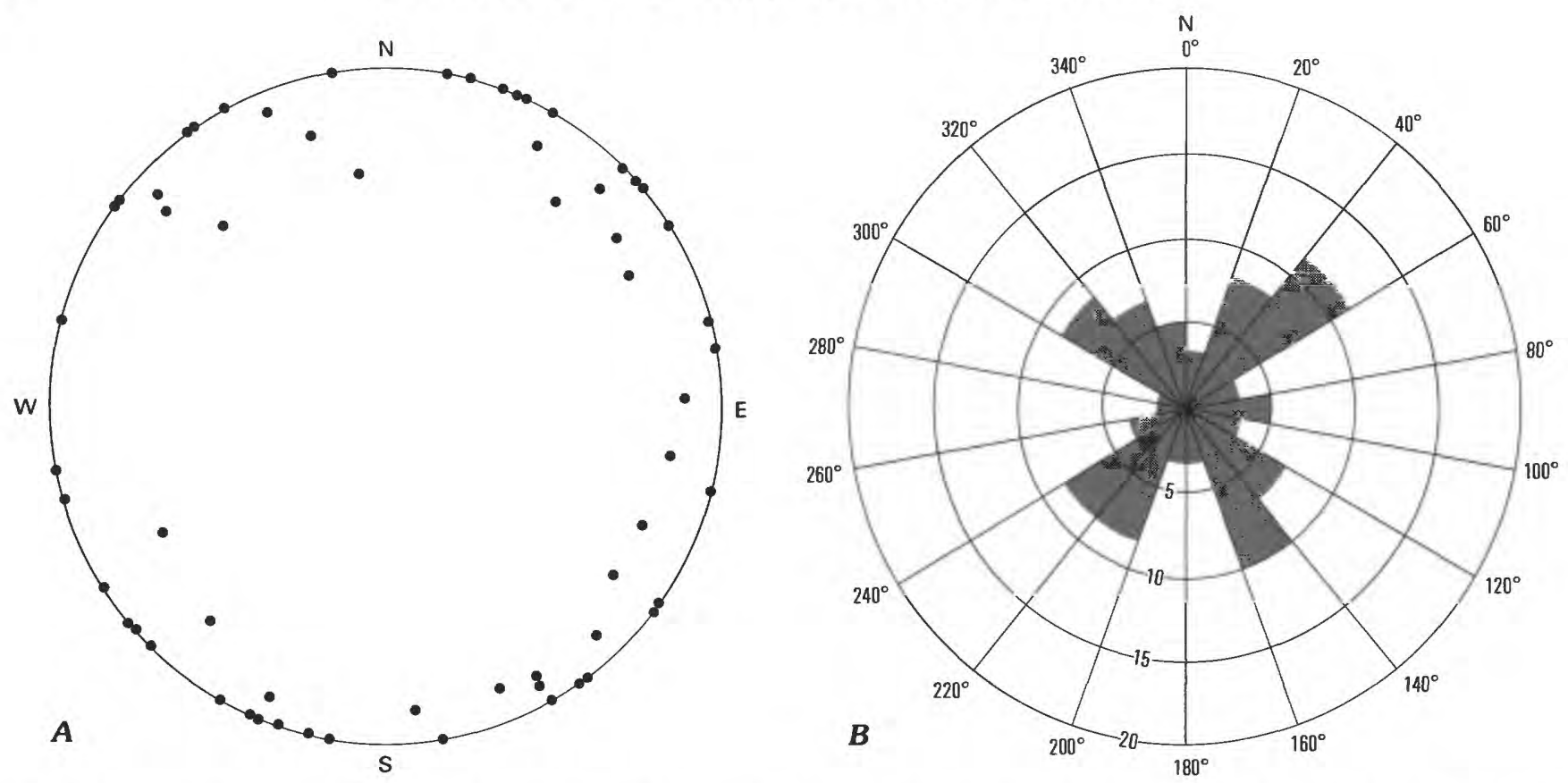

FIGURE 5.-Bone orientations at UALP locality 7498, Yavapai Co., Ariz. A, Stereographic projection; poles of bones plotted on lower surface of a stereonet. Each filled circle indicates one pole. Observations on periphery of diagram indicate horizontal bones. $B$, Rose diagram; concentric circles and associated values represent percent of total number of observations.

frequency of mandibles is low because the mandibles easily disassociate into individual rami. The lack of preferred orientation to the bones and the high number of bones in each Voorhies Group (remembering that collecting bias has lowered the number of bones in Group I) indicates that they were not transported by water.

\section{COMPARISONS WITH LOCALITY 7498}

The bone orientation and relative abundance data at the Browns Park locality D856 may be usefully compared with similar data collected by J. G. Honey at the UALP (University of Arizona Laboratory of Paleontology) locality 7498 , about $15 \mathrm{~km}$ south of Prescott, Ariz. Comparison of the two data sets suggests that water currents influenced bone deposition at the UALP locality in contrast to the Browns Park locality. The late Clarendonian UALP bone assemblage is in an area of combined fluvial and eolian sediments of the Milk Creek Formation and is similar to the bone assemblage at locality D856 in that it contains a preponderance of camelid fossils. For details of the stratigraphy and depositional interpretations, see Hook, 1956; Honey, 1977; and Honey and Taylor, 1978. The bone orientations and relative abundances, however, differ significantly between the two deposits.

In the UALP sample, the orientations of the long axes of 42 bones were plotted on a stereonet (fig $5 A$ ). About half of the bone orientations fall on the periphery of the circle, indicating that the bones were deposited horizontally. The rest of the bones have shallow dips, none exceeding $21^{\circ}$. The points tend to cluster in the northeast and northwest sections of the stereonet. The data were replotted as a rose diagram (fig. $5 B$ ), which can be compared with the rose diagram for the Browns Park bones (fig. $4 B$ ). At the UALP locality the bones form four distinct clusters. The mean of each cluster is within $7^{\circ}$ of being $90^{\circ}$ removed from its two nearest neighbors. The polarity of 14 of the bones was recorded; the heavy ends of 13 of the bones are distributed almost equally among the northwest, northeast, and southeast clusters.

The tendency for preferred orientations is strong evidence that the UALP bones have been aligned by water currents. Most significant is that the means of the four distinct clusters are within $7^{\circ}$ of being $90^{\circ}$ removed from each other; that is, the long axes of these bones tend to fall into two mutually perpendicular directions. These directions are interpreted as parallel and transverse to a water current. Generally, on bones parallel to the current direction, the large ends tend to point downstream (Voorhies, 1969); however, the orientations of the UALP bones indicate only that the current probably did not flow southwest.

All skeletal elements from UALP locality 7498 are listed in table 3 , which can be compared with table 1 
TABLE 3.-Bones from UALP locality 7498, Yavapai County, Arizona, and their distribution into Voorhies Groups

\begin{tabular}{|ll|l|l|l|}
\hline Group I & Group I/II & Group II & Group II/III & Group III \\
\hline 1 patella & 4 podials & 3 distal metapodia & 23 partial rami & 1 skul I \\
1 rib & & 2 proximal metapodia & & 1 complete mandible \\
& & 3 metapodial shafts & & \\
& & 3 distal tibiae & & \\
& & & & \\
& & & & \\
& & & & \\
\end{tabular}

for the Browns Park (locality D856) bones. A glance reveals the preponderance of ramal fragments (Group II/III) in the sample. Partial palates of at least six individuals were also recovered but are not included in the table because their transport susceptibilities were not examined by Voorhies (1969) or Behrensmeyer (1975). The preponderance of ramal fragments is strikingly illustrated by calculating the observed frequencies of cranial parts relative to the postcranial parts. In a complete skeleton, the number of rami will equal the number of tibiae, or humeri, or metatarsals, or any other paired limb element. The expected frequencies of these elements is therefore equal to one. In caniels, there are two indistinguishable proximal (or medial or distal) phalanges per metapodial. Because it is nearly impossible on isolated specimens to tell front from hind phalanges, for practical purposes a complete skeleton will have eight indistinguishable proximal phalanges. Thus, the expected frequency of rami to proximal (or medial or distal) phalanges is 1:4. The frequency of palates or skulls to phalanges should be $1: 8$.

Table 4 shows the radical departure of the observed frequencies from the expected frequencies for three taxa found at UALP locality 7498. Table 5 gives some of the data used to calculate these ratios. On Protolabis, for example, the rami occur 16 times more frequently than most of the long bones. Palates of Protolabis are 1.5 times more frequent than astragali, whereas theoretically the astragali should be twice as abundant as the palates. On the horse, a single metapodial is present; theoretically, metapodials should be twice as abundant as rami, but here they are equal. Most of the UALP locality 7498 skeletal elements belong to Group III, the lag group, or to the intermediate Group II/III. Only a single rib and patella have been recovered from Group I.

The relative abundance of the bones in the different Voorhies Groups is further evidence that the UALP bones were subject to water current action. Group I is probably slightly underrepresented, as the field notes show that a fragmentary rib shaft was found and discarded. Otherwise, collecting bias has been minimal, and the lower number of bones in Groups I, I/II, and
II reflects a real scarcity in the deposit. These bones, which are lighter than those of Groups II/III and III, would tend to be winnowed out in a water current, and the members of Groups II/III and III would remain behind as a lag deposit, as shown by the experiments of Voorhies (1969). Although carnivores might selectively drag off and eat the remains of other animals, the evidence for preferred orientations of the cranial and ramal remains argues against removal of the lighter postcranial elements by agents other than water. The nonrandom orientations of the bones and the preponderance of lag elements at UALP locality 7498 indicates the presence of a water current strong enough to both orient the bones and winnow out some of the lighter elements, as at the Verdigre deposit (Voorhies, 1969). This situation differs somewhat from that reported by Hunt (1978) at the Harper Quarry (Miocene) in Nebraska, in which a water current was strong enough to orient bones preferentially in two perpendicular directions, but not strong enough to winnow out the lighter bones. Thus, the orientations and observed ratios of the bones at UALP locality 7498 are distinctly different from those at locality D856, and indicate the difference between a lag deposit and a sedentary accumulation.

\section{PROCESSES AFFECTING DESTRUCTION AND DISPERSAL OF BONES AT LOCALITY D856}

The preservation of the bones at locality D856 gives further evidence on post-mortem events. Damage to bones shortly after an animal's death may usually be attributed to processes of weathering (climatic weathering, chemical effects of soils and roots, and bacterial activity) or to mechanisms of physical danıage (carnivore activity, trampling, fluvial transport, and diagenesis) (Behrensmeyer, 1978, p. 153; Hill, 1980, p. 143). Sediment compaction and tectonism can also danuage bones. Of these, carnivore activity and weathering best account for the condition of the bones at locality D856.

The bones from locality D856 vary in their preservation. The bones are white, gray, or brown. Tooth enamel 
TABLE 4.-Observed and expected frequencies of bones for Michenia, Protolabis, and Equidae from UALP locality 7498, Yavapai County, Arizona

[OF, observed frequency, EF, expected frequency; dist, distal; (prox), proximal]

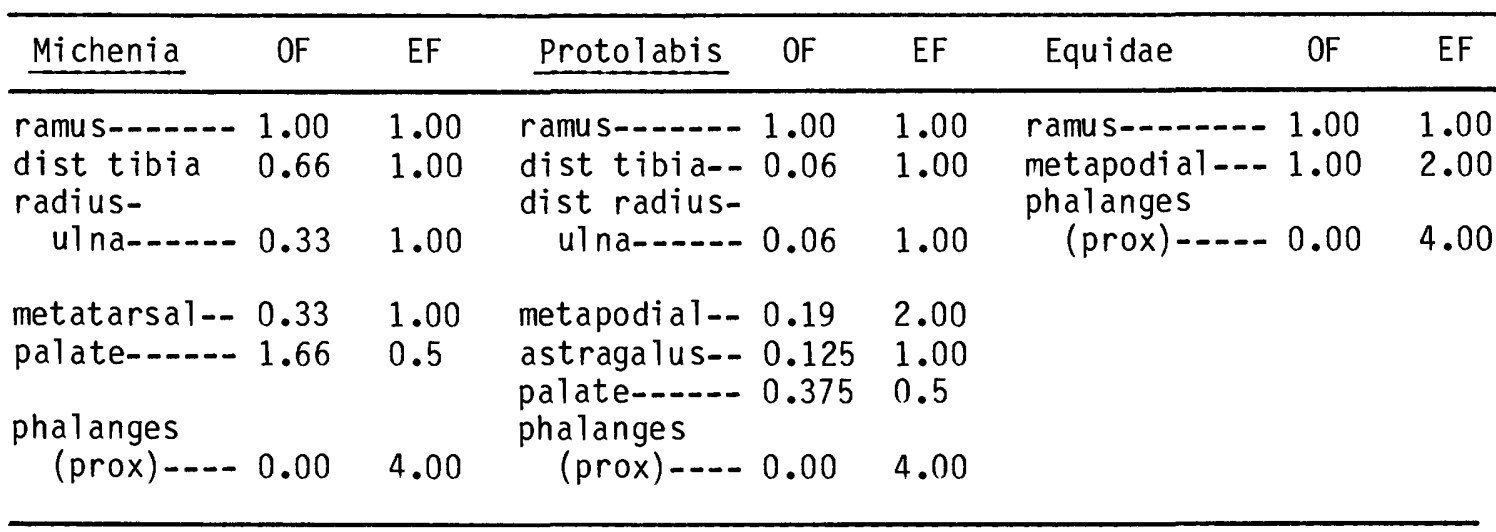

is bluish brown. Greenish-gray bones are best preserved; white and brown bones are more split and fragmented. The white color of some bones is due to a thin layer of calcium carbonate deposited on the outside surface; underneath this layer the bone is usually a shade of gray.

The greenish-gray bone is little damaged on its surface, although a few specimens (D856-32, 41) have faint, parallel cracks, and one (D856-56) is heavily damaged on the medial condyle and navicular facet. Some bones are bicolored (gray and brown, gray and white, brown and white); in nearly all cases the brown and white bone is more deeply split and fragmented than the gray bone. Several of the white bones from D856 (D856-77, 78, 28) are deeply pitted, and most show thin, parallel crackssome rather prominently (D856-25, 35). When recovered, the brown bone was commonly partially matted by living roots. In several bones, brown organic matter was concentrated along splits or in cavities. Roots growing parallel to the bedding planes sometimes led to and surrounded bone. Bone highly disintegrated by roots left a brown stain in the enclosing sediments.

Many of the bones at locality D856 have surface textures similar to those produced by weathering. For example, some bones are nearly unweathered, and have only minute cracks (D856-30, 32, 65, 82). Other bones have thin, parallel cracks and some have a fibrous texture: they resemble bones that have dried and weathered on the surface of the ground (Behrensmeyer, 1975 , pl. 1, fig. A). Other quarry bones (fig. 6, $E$ and $F)$ are deeply weathered with cancellous bone exposed.

There is, however, a strong overprint on many D856 bones caused by the destructive action of living roots. Root acids can create a pattern of etch marks on the surface of bone, or roots can grow into and split bones (Behrensmeyer, 1978, p. 154; Haynes, 1980, p. 349).
Some of the bones at locality D856 were etched and split by Holocene roots, which may have created some of the apparent Miocene weathering textures such as the shrinkage cracks. The bones with the spongiosa exposed (fig. 6, $E$ and $F$ ) however, show no traces of Holocene roots, and their texture is thus more likely to have been caused in the Miocene.

The bones vary in completeness. None of the long bones or metapodials are completely represented; most are proximal or distal ends. The ribs are represented only by their heads; fragmentary shafts probably were destroyed during collection. Complete bones include some phalanges, podials, and vertebrae. The horn core and jaws are partially broken, the scapula is extremely broken, and the pelvis is represented only by the acetabulum.

In general, the breaks and morphological details of the bones are sharp and clear. Several bones have spiral fractures (D856-62, 55, 64; figs. 6B, 6C, 6D), and a few bones (D856-25, 19; fig. 6A) have splintered fractures (compare Behrensmeyer, 1975, pl. 2, figs. A, B, C). Some bones (D856-28, 77, 78; figs. $6 E, 6 F)$ have a roughened and pitted surface similar to bones illustrated by Behrensmeyer (1975, pl. 1, figs. A, B, and C). Other bones are crushed or have broken, depressed areas. For example, a distal radius-ulna (D856-25; fig. $6 H$ ) has the posterior part of the shaft crushed inward, yet the distal end is undisturbed. A phalanx (D856-68; fig. 6G) has a crushed shaft although the proximal and distal ends are undisturbed. Nearly all bones are broken or cracked, or have rough, pitted surfaces. No bones larger than camel phalanges are preserved intact.

Some of the damage on the bones at locality D856 is attributable to breakage rather than weathering, and includes the previously mentioned crushing of several of the bones, the destruction of the more fragile shafts 
TABLE 5.-Data used to calculate observed frequencies given in table 4

Michenia

rami: 3 separate rami; 1-1/2 individuals maximum. distal tibiae: 2 separates; 2 individuals minimum. radius-ulna: 1 separate; 1 individual. metatarsal: 1 separate; 1 individual. palates: at least five "1/2 palates"1; $2-1 / 2$ individuals minimum.

Protolabis

rami: 16 separates; 9 individuals minimum.

distal tibia: 1 separate; 1 individual.

radius-ulna: 1 separate; 1 individual.

metapodials: 3 separates at most; 2(?) individuals. astragali: 2 separates; 2 individuals. palates: six "1/2 palates"; 3 individuals.

\section{Equidae}

rami: 1 separate; 1 individual.

metapodial: 1 separate; 1 individual.

$1_{\text {Refers to one-half of a complete palate, }}$ broken in the sagittal plane.

of the long bones, and spiral and splintered fracturing. According to Behrensmeyer (1975, p. 480), spiral and splintered fractures occur only on fresh bone, and their presence on several locality D856 bones may indicate that fracturing occurred before burial. Fluvial transport is one possible mechanism of physical damage. The edges of the bones at locality D856 are not rounded or polished, which indicates no prolonged current transport. Current transport of bones can result in extensive breakage without polishing, provided the transport has not been of long duration or over a great distance (compare Behrensmeyer, 1975, pl. 1, fig. B, bones a and b). However, the lack of fluvial deposits at locality D856, and the lack of indications of water transport in either the orientations or abundance of the bones, suggests no fluvial transport.

Sediment compaction or tectonic processes probably do not account for the fragmentation of the bones. The presence of dune foresets greater than $30^{\circ}$ in some of the Browns Park roadcuts suggests little or no postMiocene compaction of the sediments. Although sediment compaction or tectonism could crush the relatively fragile shafts of the long bones, these processes would probably not destroy all traces of these shafts while preserving the ends, nor would they preserve, undistorted, several delicate cervical vertebrae while crushing the larger and stronger phalanx (D856-68) and radius-ulna (D856-55). There is no direct evidence for tectonic activity in and around locality D856. Dips taken on quarry strata range from $3^{\circ} \mathrm{SE}$ to $4^{\circ} \mathrm{NW}$; slight irregularities on the dip surface and the original surface of deposition can account for these slight variations from horizontal. In the area around Maybell, the rocks are flat lying.

According to Behrensmeyer (1975, p. 482), $\mathrm{CaCO}_{3}$ deposition can destroy a bone through the outward growth of a calcite nodule. At locality D856, however, there is no evidence for $\mathrm{CaCO}_{3}$ nodule formation and the subsequent "explosion" of bone; instead, the calcite is a deposit on the surface of the bone. In some instances

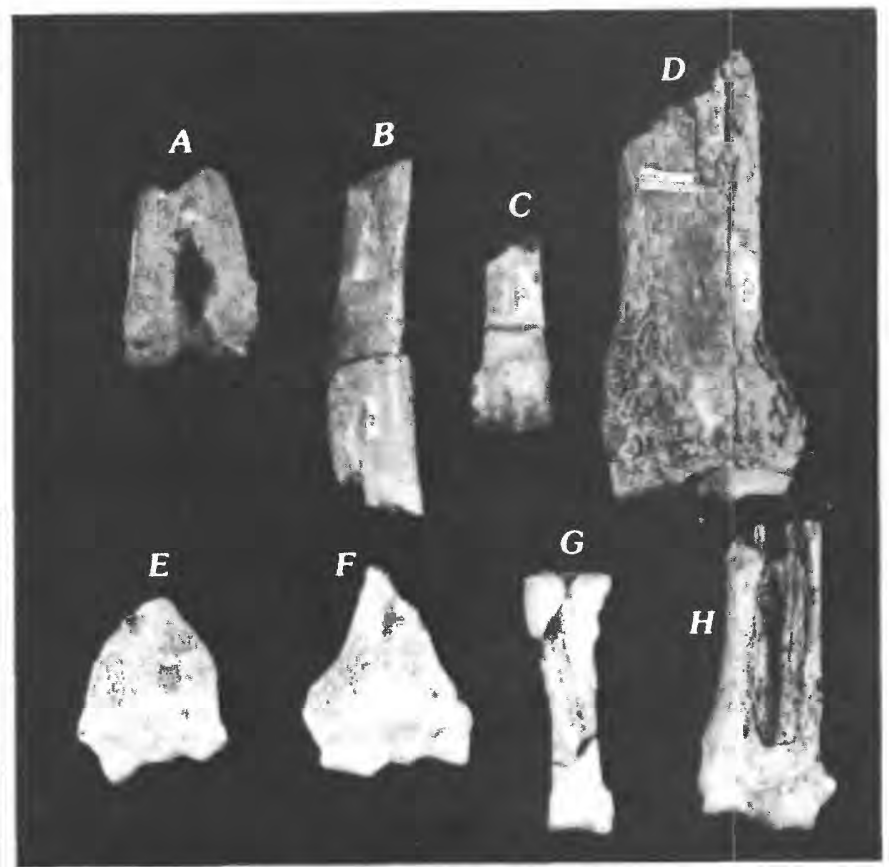

FIGURE 6.-Weathering characteristics of bones from locality D856, Citadel Plateau 15-minute quadrangle, Moffat County, Colo. A, posterior view of distal right humerus showing splintered fractures; cf. Protolabis, specimen D856-19. B, anterior view of metapodial shaft showing spiral fracture along top; Procamelus sp. or Aepycamelus sp., D856-62. C, posterior view of distal metapodial showing spiral fracture along top; Procamelus sp. or Aepycamelus sp., D856-62. $D$, anterior view of right distal radius-ulna, showing spiral fracture along top; Procamelus sp. or Aepycamelus sp., D856-55. E, anterior view of right distal radius-ulna showing pitted surface; Camelinae sp., D856-77. F, anterior view of left distal radiusulna showing pitted surface; Camelinae sp., D856-78. G, posterior view of proximal phalanx showing crushed central part of shaft; Procamelus sp. or Aepycamelus sp., D856-68. H, posterior view of left distal radius-ulna showing crushed shaft; cf. Protolabis, D856-25. Scale is in centimeters. 
(D856-37, 53) gray bone is evident underneath this surface veneer, whereas in other instances (D856-68, 77) the bone is soft and powdery. The fossil layer itself becomes more firmly cemented with calcite near its contact with the overlying highly calcareous layer, and it was from the bottom of this overlying layer that the Tomarctus skull and jaws were found. This specimen consists of gray-green bone that is remarkably well preserved, suggesting that $\mathrm{CaCO}_{3}$ deposition has not destroyed the bone.

Animal trampling and associated kicking could explain some of the features of bones from quarry D856. Trampling would tend to fragment the more fragile shafts of long bones, leaving the ends and the denser bones intact. Incidental kicking is a random dispersive process (Hill, 1979, p. 270) which, like carnivore activity, could scatter and randomly orient the bones at locality D856. Trampling, however, often orients bones at high angles (Andrews and others, 1981, p. 45; Behrensmeyer and Boaz, 1980, p. 87); because most bones at locality D856 are horizontal and none dip at high angles, trampling probably was not the major cause of the observed bone destruction.

Carnivore activity is probably the main cause of bone destruction and dispersal at locality D856. Although there are tooth marks on only one bone (a camel ulna (D856-23) has a probable gnawed area immediately below the semilunar notch), Haynes (1980, p. 343) noted that carnivore gnawing does not always leave identifiable tooth marks on bones. He also noted that removal of the outermost lamellar tissue of bone can eliminate the shallower tooth marks (1980, p. 349). Carnivore activity is indirectly suggested by the absence of proximal humeri, tibiae, proximal and distal femora, and the presence of distal humeri, radii-ulnae, tibiae, and proximal and distal metapodials. The proximal ends of the humerus and tibia, and both ends of the femur, have a high fat content, and are therefore readily eaten by carnivores (Voorhies, 1969 , p. 20 ). Haynes (1980, p. 345-347) reported extensive carnivore gnawing of these same areas on Pleistocene and Holocene bones, but notes little damage to distal ends of long bones except for the femur. According to Voorhies (1969) scavenging by carnivores possibly accounted for the low number of femora, and proximal humeri and tibiae in the Verdigre sample; Hunt $(1978$, p. 35$)$ also suggested that carnivore activity accounted for the presence of broken limb bones, isolated teeth, vertebrae and ribs at Harper Quarry. The abundance of metapodials, podials, and phalanges at locality D856 could be explained by their having been covered by less meat, thus making them less attractive dietary items to carnivores. The greater density of the podials and the proximal and distal ends of the metapodials and phalanges would also help explain their preservation.

\section{CONCLUSIONS}

Fluvial transport, sediment compaction, tectonism, and calcium carbonate deposition do not account for the observed fragmentation and destruction of the bones at locality D856. The physical damage to these bones was most likely caused by carnivore activity, with a possible minor component due to trampling. The surface textures of some of the bones may be due to Miocene weathering phenomena, but the strong overprint caused by etching and splitting due to growth of modern plant roots makes tenuous any interpretation of ancient weathering textures.

The pattern of highly fragmented bones, missing their shafts and nutrient-rich ends, and which are disarticulated and highly dispersed, indicates intense utilization of the original carcasses by carnivores. This suggests a relatively low number of carcasses available to predators when the locality D856 bone deposit accumulated. Where there is an abundance of carcasses, as can occur in catastrophic mortality, there is less utilization of each carcass by carnivores, resulting in less bone destruction and increased chance for burial of intact bones (Western, 1980, p. 48; Coe, 1980, p. 59; Behrensmeyer and Boaz, 1980, p. 85). It is unlikely that the bone assemblage at locality D856 is the result of the catastrophic death of many mammals, but is more likely the result of slow, attritional mortality. With relatively few carcasses available for the number of predators, the bones were more thoroughly consumed, resulting in a fossil deposit of fragmentary, dispersed bones.

\section{VERTEBRATE FAUNA OF THE BROWNS PARK FORMATION}

\section{LOCATIONS OF FOSSIL SITES}

The fossils described are from four localities (fig. 7; table 6): D854, south side of roadcut in the NE1/4NE1/4 sec. 23 , T. 6 N., R. 97 W., Citadel Plateau 15-minute quadrangle; D855, on a hill in the NE1/4NE1/4 sec. 36 , T. 6 N., R. 97 W., Citadel Plateau quadrangle; D856, on the same hill in NW1/4NW1/4 sec. 31 , T. 6 N., R. 96 W., Citadel Plateau quadrangle; D857, in a roadcut in SW1/4NW1/4 sec. 34, T. 6 N., R. 97 W., Elk Springs 15 -minute quadrangle. Locality D855 is $15.2 \mathrm{~m}$ stratigraphically below locality D856. Extensive plant cover prevents direct stratigraphic correlation between the rocks at localities D854 and D855. D854 lies topographically $32.6 \mathrm{~m}$ below D855 at an elevation of 1,930 m. Similarly, fossil locality D857 cannot be correlated stratigraphically with the other fossil localities. 


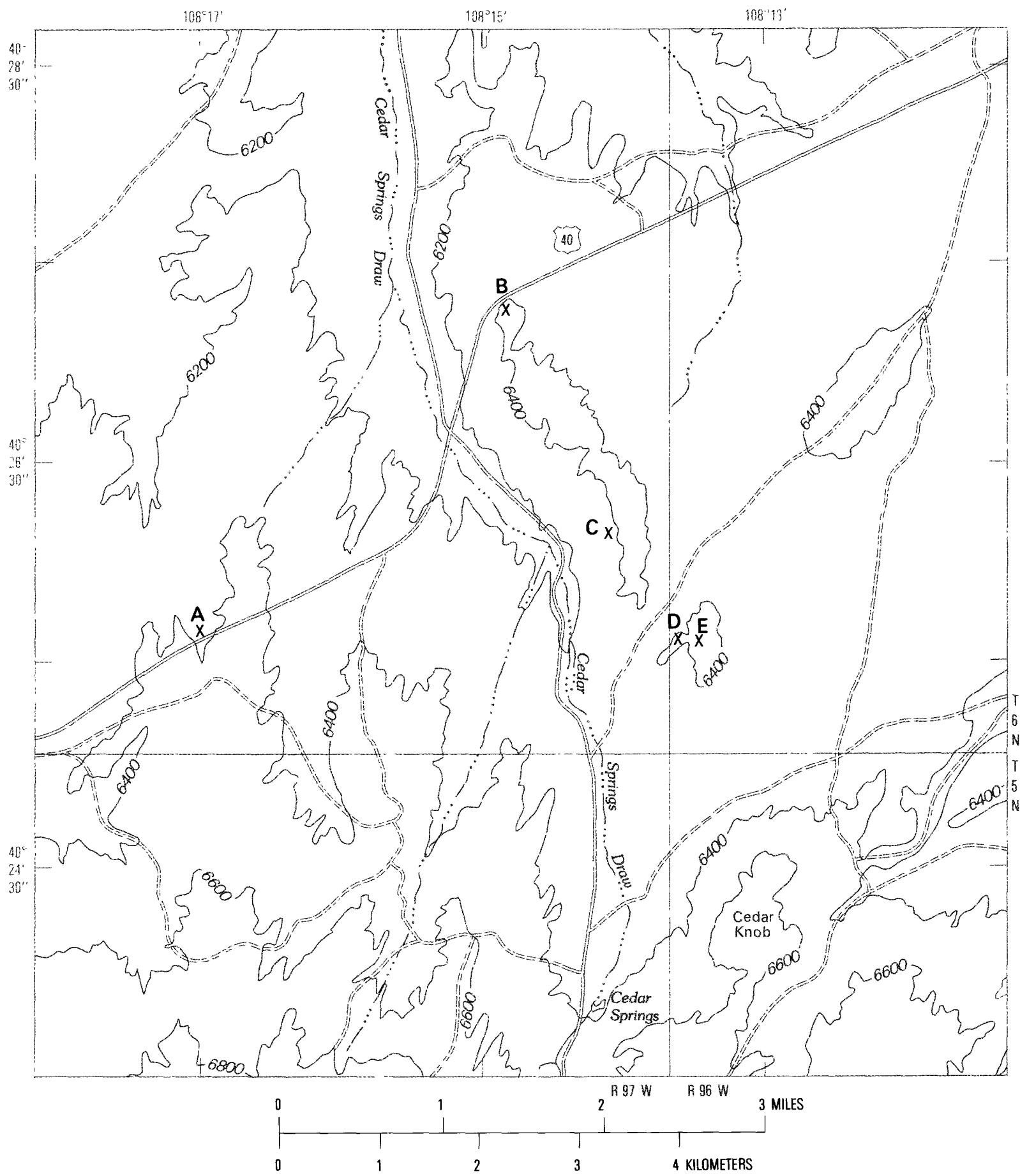

FIGURE 7.-Fossil mammal localities and dated volcanic ash southwest of Maybell, Colo. A, locality D857; B, D854; C, dated ash; D, D855; E, D856. Topographic base from Citadel Plateau and Elk Springs 15-minute quadrangles, Moffat County, Colo. Elevations are in feet; to convert to meters, multiply by 0.3048 . Double dashed lines indicate unimproved dirt road.

Its elevation is about $1,963 \mathrm{~m}$, which is the same as at D855 (1,962 m).

The fossils found at these four sites are assigned to two local faunas distinguished by taxonomic and temporal differences. The term local fauna, as used in this paper, follows that given by Tedford (1970, p. 682-683). He stated that "the local fauna may be represented by samples from a single site or a series of closely associated sites having a limited geographic and stratigraphic distribution." Although the four sites in 


\begin{tabular}{|c|c|c|}
\hline \multicolumn{2}{|c|}{$\begin{array}{l}\text { Locality } \\
\text { No. }\end{array}$} & Fossils \\
\hline \multicolumn{3}{|c|}{ Cedar Springs Draw local fauna } \\
\hline D854 & $\begin{array}{l}\text { Sandstone, white, quartzitic, medium- } \\
\text { grained, subrounded, friable. }\end{array}$ & Meryceros $\mathrm{sp}$ \\
\hline $\mathrm{D} 855$ & $\begin{array}{l}\text { Sandstone, white, very fine to fine- } \\
\text { grained, silty; in part calcareous. }\end{array}$ & $\begin{array}{l}\text { Procame lus } \mathrm{sp} \text {. or } \\
\text { Aepycamelus } \mathrm{sp} \text {. }\end{array}$ \\
\hline D856 & $\begin{array}{l}\text { Sandstone, light greenish-gray, fine- } \\
\text { grained, subrounded; in part calcareous. }\end{array}$ & $\begin{array}{l}\text { Tomarctus cf. T. paula } \\
\text { Megahippus sp. } \\
\text { cf. Protolabis } \\
\text { Micheniasp. } \\
\text { ProcameTus sp. or } \\
\text { Aepycamelus sp. } \\
\text { CameTinae sp. } \\
\text { Meryceros warreni } \\
\text { Merycodontinae sp. }\end{array}$ \\
\hline \multicolumn{3}{|c|}{ Cross Mountain local fauna } \\
\hline D857 & $\begin{array}{l}\text { Sandstone, greenish-gray, quartzitic, fine- } \\
\text { grained, subangular to subrounded, } \\
\text { well-sorted. }\end{array}$ & $\begin{array}{l}\text { Parahippus cf. } P \text {. } \\
\text { Bliconensis }\end{array}$ \\
\hline
\end{tabular}

the Maybell area are close geographically and topographically, the fauna at one site is older than the other three. The older fossil assemblage is here named the Cross Mountain local fauna, based on its nearness to the old settlement of Cross Mountain in the Elk Springs 15-minute quadrangle; the younger fossil assemblage is here named the Cedar Springs Draw local fauna, based on its proximity to a dry wash of that name on the eastern edge of the Elk Springs 15-minute quadrangle and the western edge of the Citadel Plateau 15-minute quadrangle.

\section{MAMMALIAN PALEONTOLOGY \\ Class MAMMALIA Linnaeus Order CARNIVORA Bowdich Family CANIDAE Gray Subfamily CANINAE Gray \\ Genus TOMARCTUS Cope Tomarctus ef. T. paula Henshaw}

Table 7, Figure 8

Tomarctus paulus Henshaw (1942, p. 105-108, pl. 2, figs. $3,4,4$ a).
Holotype-CIT 1229, palate with $\mathrm{I}^{1}-\mathrm{M}^{2}$, and left ramus with $\mathrm{I}_{2}-\mathrm{M}_{3}$, from CIT locality 172 , Esmeralda Formation, 9 miles north of Tonopah, Nye County, Nev. Referred material.-D856-1: broken skull with fragmentary $\mathrm{LM}^{1}$ and complete $\mathrm{LM}^{2}$, a right dentary with canine root, $P_{1}$ alveolus, $P_{2}$ roots, fragmentary $P_{3}$, $M_{1-3}\left(M_{1-2}\right.$ damaged); D856-2, right premaxillary and maxillary with $\mathrm{I}^{3}, \mathrm{C}, \mathrm{P}^{1}$; D856-3, condyle of left dentary; D856-4, temporal fossa of left dentary; D856-88, isolated, broken teeth.

Distribution and age-Holotype from Tonopah fauna, Nevada; Barstovian land mammal age.

Description.-The skull of Tomarctus cf. T. paula is smaller than that of Canis latrans, with a relatively shorter preorbital portion, and the braincase is less expanded. The zygomatic arches are widely flaring which, coupled with the small braincase, results in temporal fossae relatively larger than in C. latrans.

The width across the piriform aperture is the same as in C. latrans. A small tuberosity on the dorsal border of the premaxillary is more prominent on specimen D856-1 than on $C$. latrans. The incisor alveoli are transversely narrow, and the alveolus for the $\mathrm{I}^{3}$ is much larger than that for either the $\mathrm{I}^{1}$ or $\mathrm{I}^{2}$. 
The muzzle is short and deep, with the maxillary nearly as deep but only about half as long antero-posteriorly as in some specimens of $C$. latrans. The muzzle is less broad than that of $C$. latrans. The lateral edge of the palatine between $\mathrm{P}^{4}$ and $\mathrm{M}^{1}$ is strongly depressed.

A large maxillary foramen is located anteriorly on the orbital border of the maxillary. Alveolar foramina are present on the dorsal surface of the maxillary tuberosity. The sphenopalatine and posterior palatine foramina are located $14 \mathrm{~mm}$ posteromesial to the maxillary foramen, on the dorsal part of the palatine bone. The rest of the medial wall of the orbit has been destroyed.

The jugal-maxillary contact is V-shaped, with a prominent ventral maxillary process on the jugal. The scar for the origin of the masseteric muscle is pronounced, with the upper margin marked by a distinct ridge. The frontal process of the jugal is mesially inclined.

On the partial right frontal, the external frontal crest trends posteromesially from the zygomatic process to meet its counterpart at the midline and form a strong sagittal crest. The parietals are less inflated than in $C$. latrans. The lambdoidal crest has a more strongly developed posterior flare than in C. latrans, and forms a broad, inverted U. Owing to this marked flaring, the posterior surface of the supraoccipital is highly concave on $T$. cf. T. paula. The external occipital crest is poorly developed, whereas on C. latrans it is a marked swelling above the foramen magnum. Several dorso-ventrally trending ridges and depressions, for the insertion of the splenius muscle, are present on the supraoccipital.

The foramen magnum and basioccipital are destroyed. Laterally, the lambdoidal crest extends anteroventrally as a strong shelf to join the posterior root of the zygomatic arch. A prominent tubercle is located on the crest and posterodorsal to the auditory meatus. The partially broken bulla is mesiolaterally elongated and less expanded than in C. latrans. In C. latrans, the bulla is inflated so that its lower border lies below the lowermost portion of the retroglenoid process, whereas on specimen D856-1 the bottom of the bulla is level with the bottom of the process. Owing to this expansion, in C. latrans the bullar fusion of the squamosal occurs further down on the retroglenoid process than on specimen D856-1. The lower lip of the external auditory meatus, which on specimen D856-1 lies above the opening of the retroglenoid foramen, is level with or below the opening for this foramen in C. latrans. Owing to the less expanded bulla in specimen D856-1, the stylomastoid process is much more prominent and extends below the level of the bulla.

Parts of the basisphenoid and orbitosphenoid are preserved. The posterior opening of the alar canal and the foramen rotundum are smaller, but situated much as in C. latrans. On specimen D856-1, a tiny foramen
TABLE 7.-Skull and dental measurements of Tomarctus $c f$. T. paula (specimen D856-1) from locality D856 in the Citadel Plateau 15-minute quadrangle, Moffat County, Colorado

[Measurements in millimeters]

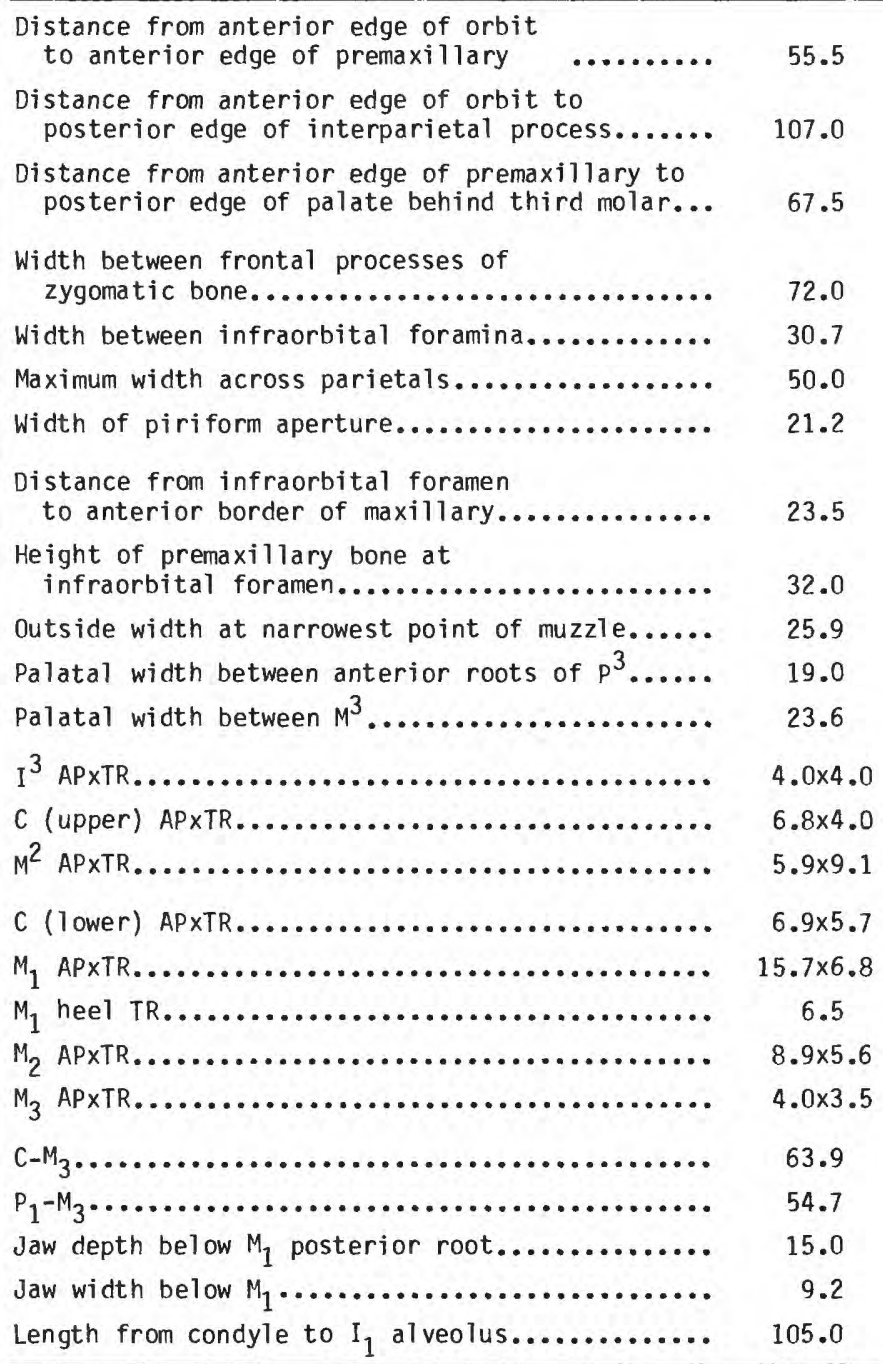

is present in the position of the hypophyseal fossa; the dorsum sellae is broad and flat.

An isolated $\mathrm{I}^{1}$ (specimen D856-88) possesses a broad central cusp bounded laterally by a smaller accessory cusp. The small mesial accessory cusp may have been eliminated by wear. The lingual surface of the tooth is concave and bounded by a broad cingulum. The $\mathrm{I}^{3}$ (specimen D856-2) is larger and more caniniform than the $I^{1}$ and has a minute posterior swelling. There is a mesial cingulum at the base of the tooth. The canine is robust and laterally compressed.

The premolars of specimen D856-1 are highly fragmented. A partial $\mathrm{P}^{4}$ consists of a paracone and metastyle separated by a notch. A strong cingulum runs along the base of the lingual wall. A fragmentary $\mathrm{M}^{1}$ shows no differences from that of $C$. latrans. The $\mathrm{M}^{2}$ 

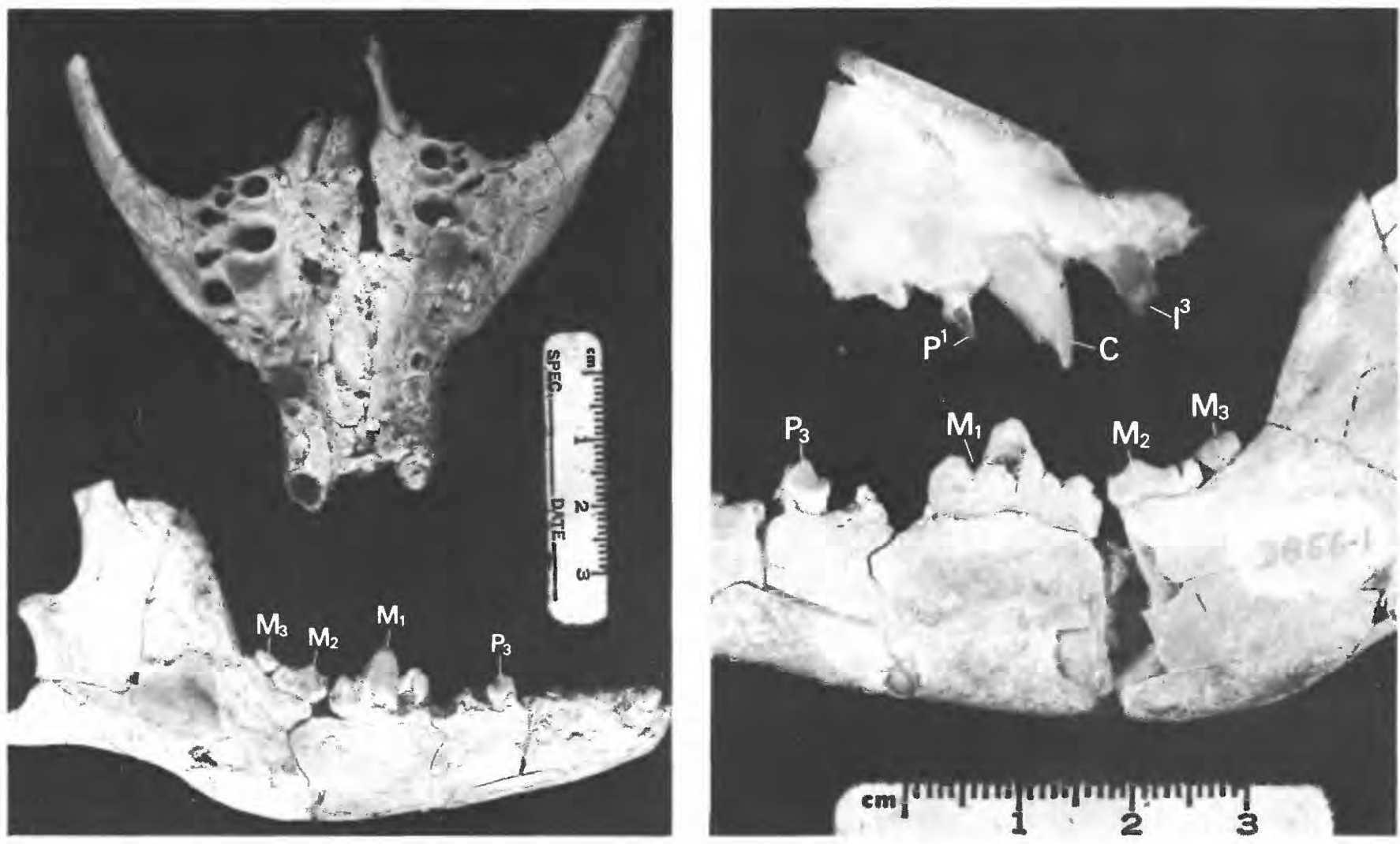

Figure 8.-Tomarctus cf. T. paula, from locality D856, Citadel Plateau 15-minute quadrangle, Moffat County, Colo. Upper left, ventral view of palate; specimen D856-1. Lower left, buccal view of right dentary showing premolar $\left(\mathrm{P}_{3}\right)$ and molars $\left(\mathrm{M}_{1-3}\right)$ of specimen D856-1. Upper right, lateral view of rostrum showing right incisor $\left(\mathrm{I}^{3}\right)$, canine $(\mathrm{C})$, and premolar $\left(\mathrm{P}^{1}\right)$ (broken) of specimen D856-2. Lower right, lingual view of right dentary showing $P_{3}$ and $M_{1-3}$ of specimen D856-1.

metacone is smaller in relation to the paracone, and the $\mathrm{M}^{2}$ buccal cingulum is weaker and the posterior edge of the tooth is less concave than that of $C$. latrans.

The lower canine root on specimen D856-1 indicates a large, vertically oriented tooth. The $\mathrm{C}-\mathrm{P}_{1}$ diastema is slightly shorter than that of $C$. latrans. The premolars are too fragmented to be described. The $M_{1}$ is broken anterobuccally. The protoconid, paraconid, and metaconid are all strongly developed; the metaconid more so than that of $C$. latrans. Small lingual and buccal accessory cusps are present on the posterior walls of the metaconid and protoconid, respectively. On specimen D856-1, the lingual accessory cusp is more closely appressed to the metaconid than on $C$. latrans. The posterior wall of the $M_{1}$ talonid is broken, but it appears that the posterior cingulum is less well developed than in C. latrans. The $\mathrm{M}_{2}$ has some slight anterobuccal breakage. The protoconid and metaconid are well developed on specimen D856-1, and in addition there is a small anterior paraconid-a cusp absent on the $\mathrm{M}_{2}$ of $C$. latrans. The $\mathrm{M}_{3}$ is round and simple with two shallow anterior and posterior basins.
The dentary of specimen D856-1 is short and slender. The ventral border is convex beneath the molars, and concave beneath the masseteric fossa. Owing to the shortness of the jaw, the ventral border anterior to the molars is less rounded than in $C$. latrans. A large mental foramen is located beneath the anterior root of the $\mathrm{P}_{2}$. The masseteric fossa is deeply excavated. The articular condyle is slightly less elongate laterally than in C. latrans. The posterior border of the symphysis lies between the $\mathrm{P}_{1}$ and $\mathrm{P}_{2}$.

Comparisons and discussion.-Specimen D856-1 resembles Tomarctus rather than Canis in having a short facial region, small braincase, strong lambdoidal crest (McGrew, 1935, p. 305) and a distinct paraconid on the $M_{2}$ (Merriam, 1913, p. 360). The presence of $M_{1}$ accessory cusps distinguishes specimen D856-1 from Cynodesmus (Olsen, 1956, p. 2).

Specimen D856-1 is about 25 percent smaller than Tomarctus rurestris (Condon, 1896), figured by Downs (1956, figs. 10 and 11). The dentary is more robust and more strongly convex anterior to the masseteric fossa in $T$. rurestris. 
The type of Tomarctus brevirostris (Cope, 1873) is a fragmentary jaw with the $M_{1}$ present; the $M_{1}$ is about 40 percent larger than that of specimen D856-1. The jaws from the Lower Snake Creek fauna (early Barstovian) referred by Matthew $(1924$, p. 91) to T. brevirostris, average about 20 percent larger than specimen D856-1. The teeth are wider and more massive and the dentary is more robust in $T$. brevirostris. The skull is larger, the palatal width at the $M_{1}$ is about 29 percent greater, and the auditory bulla is more inflated in $T$. brevirostris.

The type lower dentition of Tomarctus optatus Matthew, 1924 (Matthew, 1924, fig. 18) is only slightly larger than that of specimen D856-1. The molar widths are the same, and the referred jaws in the AMNH do not differ from specimen D856-1. However, the upper dentition of undescribed T. optatus in the AMNH collection is larger than that of specimen D856-1. In particular, the $\mathrm{M}^{2}$ of $T$. optatus is less reduced than that of specimen D856-1, and consequently, $T$. optatus more closely resembles other small species of Tomarctus which have nonreduced dentitions.

Tomarctus confertus (Matthew, 1918) has a smaller, shorter skull, with narrower palate and less expanded braincase, than specimen D856-1. The mandible of $T$. confertus (AMNH 17203; Matthew (1918), fig. 1) is shorter and narrower dorsoventrally, the premolars are shorter, the canine smaller, and the $M_{1}$ narrower than that of specimen D856-1.

Tomarctus euthos (McGrew, 1935), has a bigger skull with wider rostrum and palate than that of specimen D856-1, and the rostrum is not sharply constricted anterior to the $\mathrm{P}^{4}$ as it is in specimen D856-1. The teeth of $T$. euthos are more robust than those of specimen D856-1.

Tomarctus propter Cook and Macdonald, 1962, based only on an $\mathbf{M}_{1}$, is distinguished from specimen D856-1 by being much larger and having a reduced metaconid.

The tooth row of Tomarctus canavus (Simpson, 1932), is 8-13 percent longer than specimen D856-1. Although the morphology of the lower molars is similar in specimen D856-1 and T. canavus, the molars of $T$. canavus are slightly larger than those of specimen D856-1. The upper teeth of $T$. canavus (including the types of T. thomasi White, 1941 and Nothocyon insularis White, 1942) are distinctly larger than those of specimen D856-1. In particular, the $\mathrm{M}^{2}$ of specimen D856-1 is much reduced compared to the $\mathrm{M}^{2}$ of $T$. canavus (Olsen, 1956, tables 1 and 2). Although the $M^{1}$ of specimen D856- 1 is broken, the transverse width is less than that of $T$. canavus.

Tomarctus casei (Wilson, 1939), is smaller than $T$. canavus, and has a shorter dentition than that of specimen D856-1 (measured from the back of the canine to the back of the $\mathrm{M}^{3}$ ). Although the transverse width of the $\mathrm{M}^{1}$ of $T$. casei is less than that of specimen D856-1, the $\mathrm{M}^{2}$ of $T$. case $i$ is wider-about the size of the $\mathrm{M}^{2}$ of $T$. canavus. On $T$. casei the $\mathrm{M}^{2}$ ectocingulum is stronger than on specimen D856-1, and there is a marked concavity on the posterior edge of the tooth not present on specimen D856-1.

Tomarctus thomsoni (Matthew, 1907) is distinguished from specimen D856-1 by having a less reduced $M^{2}$, with a more expanded posterointernal corner. In specimen D856-1 the premolar row is longer, the $M_{1}$ is slightly longer, the $M_{2}$ is longer and wider with a narrower talonid, and the $M_{3}$ is slightly more reduced than that of T. thomsoni.

Tomarctus kelloggi (Merriam, 1911) is distinguished from specimen D856-1 in having a more robust jaw and an enlarged $M_{2}$ with a well developed paraconid. On a referred $M_{2}$ (UCMP 10651), the paraconid is nearly as large as the metaconid, whereas on specimen D856-1 the paraconid is relatively small. The trigonid basin on T. kelloggi is wider than that of specimen D856-1.

Specimen D856-1 is quite similar to Tomarctus paula Henshaw, $1942^{1}$. T. paula resembles specimen D856-1 in the reduction of the $\mathrm{M}^{2}$, which is greater than in the other small species of Tomarctus. The morphology of the $\mathrm{M}^{2}$ is also similar; although $T$. paula appears to have a stronger lingual cingulum, that of specimen D856-1 is broken and thus reduced in size. As indicated by the length of the lower dentition, $T$. paula is slightly shorter faced than specimen D856-1, and the $P_{1}-M_{3}$ length of $T$. paula is about 7 percent shorter than that of specimen D856-1. The $P_{1}-M_{3}$ length is probably a truer measure of the relative size of these two animals than is the length given for the condyle to the $I_{1}$; in both fossils this latter measurement is approximate and Henshaw's (1942, pl. 2, fig. 4) drawing shows that the position of the condyle is hypothetical. As in specimen D856- 1 , the posterior part of the palate on T. paula is relatively wide. The lower teeth of $T$. paula are slightly smaller than those of specimen D856-1.

Henshaw's (1942, pl. 2, fig. 4) illustration shows that the $\mathrm{M}_{1}$ metaconid on $T$. paula is the size of that on specimen D856-1. The $\mathrm{M}_{2}$ of T. paula is not elongated in relation to the $\mathrm{M}_{1}$ as it is in T. kelloggi. Henshaw $(1942$, p. 106) noted the presence of a "distinguishing paraconid" on the $\mathrm{M}_{2}$, but his illustration (1942, pl. 2,

\footnotetext{
${ }^{1}$ Tomarctus paula was originally named Tomarctus paulus. According to G. G. Simpson (written commun., 1977), Tomarctus is feminine in gender in Latin and paulus is masculine. According to Article 30 of the 1971 International Code of Zoological Nomenclature, adjectival specific names must agree with the generic name in gender, and (Article 34) must be changed, if necessary, to conform to the gender of the generic name. Thus, the change from paulus to paula is a "justified emendation" (Article 33).
} 
fig. 4a) shows only a strong crest anterior to the protoconid and metaconid. Wear sometimes causes the paraconid to lose its cuspate form and become incorporated into an anterior ridge. Other small differences with specimen D856-1 include a slightly greater depth anteriorly on the dentary, a greater inclination from the horizontal of the ascending part of the ramus, and a slightly narrower masseteric fossa.

Canid indet. BEG 31081-1255 (Wilson, 1960, p. 994, Fig. 5e) is similar to both specimen D856-1 and T. paula. The partial palate of Wilson's specimen has a reduced $\mathrm{M}^{2}$ similar in size to that of D856-1.

Specimen D856-1 and the type lower jaw of Tomarctus temerarius (Leidy, 1858) are almost identical; there are no significant size differences in either the $M_{1}$ or the dentary. Although a labial accessory cusp does not appear in Leidy's (1869, pl. 1, fig. 12) illustration of the $M_{1}$, it may have been eliminated by wear.

Similarly, the type of Tomarctus marylandica ${ }^{2}$ Berry, 1938 cannot be distinguished from the $M_{1-2}$ of specimen D856-1. Berry (1938, p. 159) noted that in $T$. marylandica, "the protoconid, the most outstanding feature of the tooth, is about twice as high as the metaconid." The $M_{1}$ metaconid on specimen D856-1 stands only slightly over half the height of the protoconid, and is thus similar to that of T. marylandica. On the $\mathrm{M}_{2}$ of $T$. marylandica a tiny basin is present posterior to the ridge between the entoconid and hypoconid. This depression was probably caused by overlap by the succeeding $\mathrm{M}_{3}$, and is therefore due to crowding of the last two molars. On specimen D856-1 the $M_{3}$ is closely appressed against the $M_{2}$. The upper teeth of $T$. marylandica are unknown.

Although the $M_{1}$ of specimen D856-1 cannot be distinguished from that of $T$. temerarius, or the $\mathrm{M}_{1}$ heel and the $M_{2}$ of specimen D856-1 cannot be distinguished meaningfully from $T$. marylandica, specimen D856-1 skull and jaws are not referred to either of these species: specimen D856-1 in fact closely resembles the more completely known $T$. paula. $T$. paula and specimen D856-1 are both short-faced forms with reduced $\mathrm{M}^{2}$, and the measurements on the upper molars of the two are nearly identical. Nothing is published of the skull proportions of $T$. temerarius or $T$. marylandica, so it is premature to assign the brachycephalic specimen D856-1 skull to either of these species. For this reason, specimen D856-1 is assigned to Tomarctus cf. T. paula.

\footnotetext{
${ }^{2}$ Tedford and Hunter (1984) suggested that $T$. marylandica is a primitive member of the genus Cynarctus.
}

\author{
Order PERISSODACTYLA Owen \\ Suborder HIPPOMORPHA Wood \\ Family EQUIDAE Gray \\ Genus MEGAHIPPUS McGrew \\ Megahippus sp. \\ Table 8, Figure 9
}

Referred material.-D856-5, right premaxillary; D856-6, 10 incisors; D856-7, $\mathrm{dP} \times(?) ; \mathrm{D} 856-8$, right and left $\mathrm{dP}_{1} ; \mathrm{D} 856-9$, right dentary with $\mathrm{dP}_{1-4}, \mathrm{M}_{1}$; D856-10, LdP ${ }_{\mathrm{x}}($ ?).

Description.-The right premaxilla preserves the symphysis and the three incisor alveoli. The anterodorsal border of the premaxilla is elevated posterior to the symphysis. The alveoli for the $\mathrm{I}^{1}$ and $\mathrm{I}^{2}$ are subequal in size and larger than the alveolus for the $\mathrm{I}^{3}$.

None of the incisors were found socketed, but their number suggests that some came from the lower jaw. The incisors, all probably deciduous, are low crowned and strongly cupped, and have long, strong roots. Five slightly worn incisors possess narrow, discontinuous lingual cingula. The labial surface is smooth or may have a cingulum running continuously along three sides. The broken $\mathrm{dP}^{\mathrm{x}}($ ?) is low crowned with a cingulum anterior to the slightly worn protocone, and between the hypocone and hypostyle.

The $\mathrm{dP}_{1}$ is large and single rooted, consisting of a prominent central cusp, swollen basally, from which sharp anterior and posterior crests descend. A strong basal cingulum is present buccally. The cingulum is more shelflike anteriorly and posteriorly than centrally.

The $\mathrm{dP}_{2}$ is elongate and relatively narrow anteriorly. A labial basal cingulum runs from the cusp-like parastylid to the hypostylid, and is more strongly developed on the hypolophid than on the protolophid. A short, shallow groove about $2 \mathrm{~mm}$ long separates the metaconid and metastylid. The $\mathrm{dP}_{3}$ and $\mathrm{dP}_{4}$ each have a strong, shelflike buccal cingulum running from the paralophid to the hypostylid. The hypostylid has a short, posteriorly directed shelf that does not reach the base of the tooth. The metaconid and metastylid are separated by a groove $2 \mathrm{~mm}$ long. The $\mathrm{dP}_{2}$ paralophid and protolophid are more widely separated than those of the $\mathrm{dP}_{3}$ and $\mathrm{dP}_{4}$. The anterior and posterior walls of the $\mathrm{dP}_{2}$ protoconid join to form a sharp buccal ridge; on the $\mathrm{dP}_{3}$ and $\mathrm{dP}_{4}$ this junction is wide and rounded. None of the deciduous premolars have a lingual cingulum. The $M_{1}$ is unerupted and incomplete. The metaconid and metastylid are only faintly separated lingually. A remnant of a cingular structure is present lingually at the bottom of the postflexid.

The mandible is deep dorsoventrally and flat ventrally. It is eroded anteriorly, but there is evidence of strong 
TABLE 8.-Dental measurements of Megahippus sp. from locality D856, Citadel Plateau 15-minute quadrangle, Moffat County, Colorado

[Measurements in millimeters]

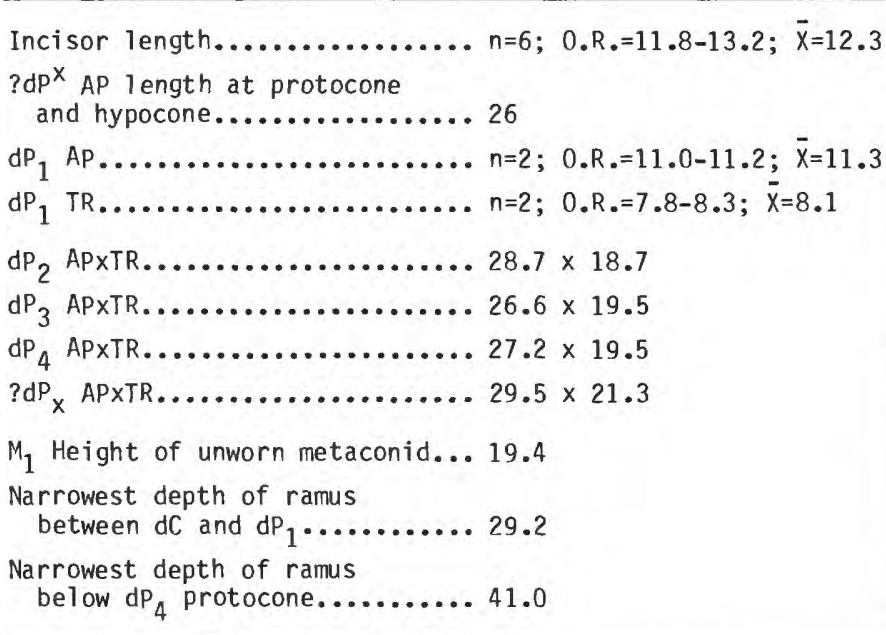

upturning at the symphysis. The post-canine diastema is short. The mental foramen is $14.5 \mathrm{~mm}$ below the $\mathrm{dP}_{1}$.

Comparisons and discussion.-McGrew (1938, p. 315) defined Megahippus on the basis of $M$. matthewi found at the Burge quarry in the Burge Member of the Valentine Formation, Neb. Although about one-fourth smaller than M. matthewi, and thus similar in size to Hypohippus affinis, specimen D856-9 differs from $H$. affinis in having a strongly upturned symphysis, short postcanine diastema, and more hypsodont $M_{1}$. A strongly upturned symphysis, short post-canine diastema, and more hyposodont dentition were among the characteristics considered diagnostic of Megahippus by McGrew. M. F. Skinner of the AMNH (oral commun., 1975), notes that the lower cheek teeth of later Megahippus possess lingual cingula, whereas those of Hypohippus do not. Examination of anchitheriines in the Frick collection corroborates Skinner's statement. In New Mexico, Megahippus from the Pojoaque Member of Galusha and Blick (1971) of the Tesuque Formation possess the lower lingual cingula on the permanent dentition. In contrast, specimens from the stratigraphically lower Skull Ridge Member of Galusha and Blick (1971) of the Tesuque Formation lack the cingula. The small cingular structure below the $M_{1}$ postflexid of specimen D856-9 is suggestive of, but not so well developed as, the cingular structures seen on the Clarendonian Megahippus cf. M. matthewi from the Esmeralda Formation at Cedar Mountain, Nev. (Mawby, 1968, fig. 1).
The lower lingual cingula of Megahippus progressively increased in size during the Barstovian. This increase in size probably correlates with the progressive development of the lingual cingula on the upper premolars of Megahippus. Tedford and Alf (1962, p. 119) pointed out that the upper premolar cingula of the late Barstovian form $M$. mckennai are less well developed than those of the latest Barstovian and Clarendonian form $M$. matthewi.

McGrew (1938, p. 315-317) considered the absence of $\mathrm{P}_{1}$ diagnostic of Megahippus. However, specimens in the Frick collection show that some early Barstovian (Pawnee Creek Formation of Galbreath (1953) in
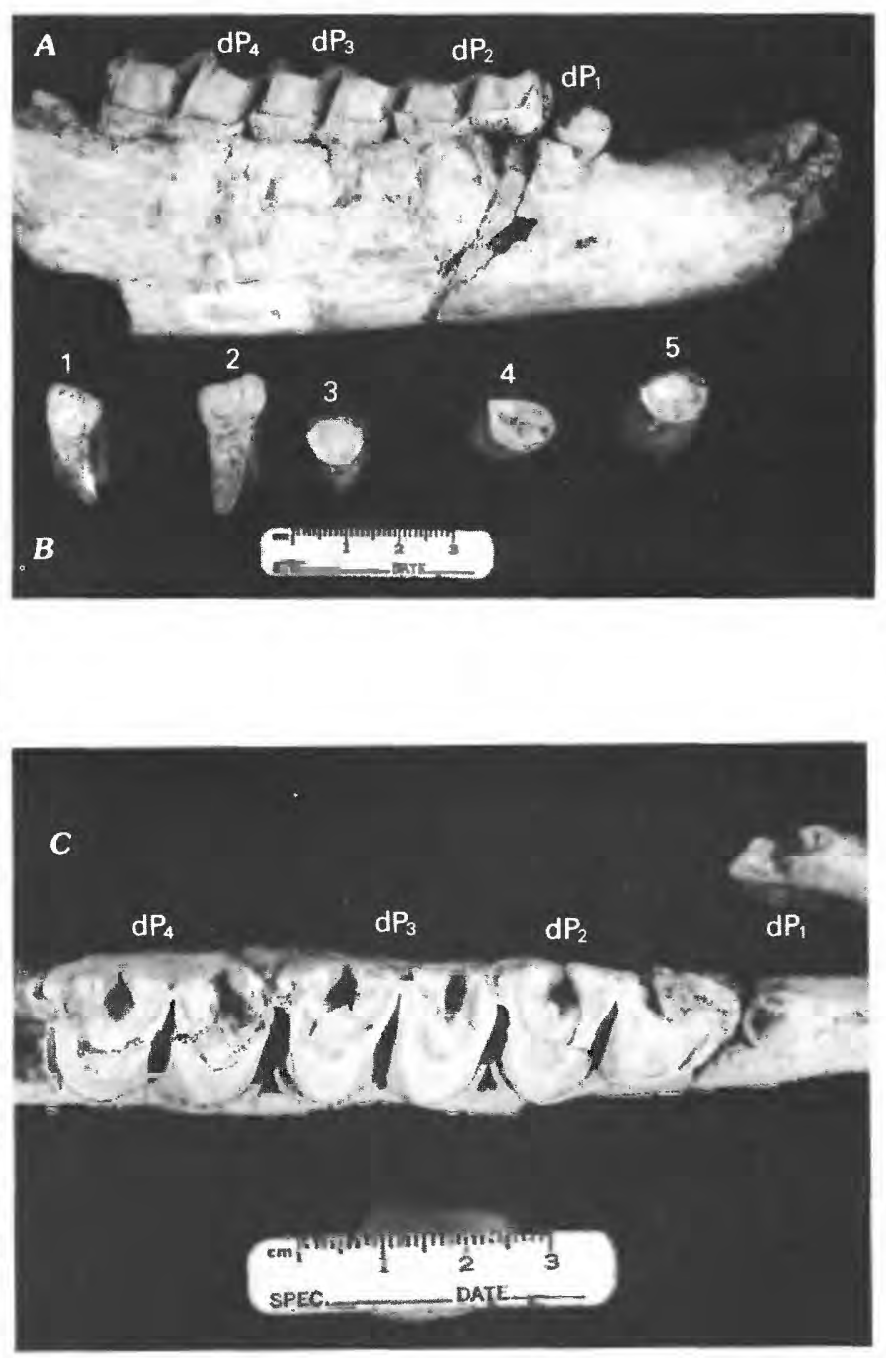

Figure 9.-Megahippus sp., from locality D856, Citadel Plateau 15-minute quadrangle, Moffat County, Colo. $A$, buccal view of right dentary with deciduous premolars $\left(\mathrm{dP}_{1-4}\right)$ of specimen D856-9. $B$, labial $(1,2)$ and occlusal $(3-5)$ views of incisors; D856-6. $C$, occlusal view of right deciduous premolars $\left(\mathrm{dP}_{1-4}\right)$ of specimen D856-9. 
northeast Colorado) forms have a well-developed $\mathbf{P}_{1}$. Some late Barstovian to possibly early Clarendonian (Pojoaque Member of the Tesuque Formation) forms have a reduced $\mathrm{P}_{1}$, and some latest Barstovian (Burge quarry $)^{3}$ forms lack the $P_{1}$. Similarly, the $\mathrm{dP}_{1}$ is well developed in the early Barstovian forms and is small or absent in latest Barstovian and Clarendonian forms.

Cupped incisors are characteristic of adult Megahippus, but are also occasionally found in adult Hypohippus. Deciduous incisors of both genera are cupped.

The features listed above and comparison of fossil horse D856-9 with specimens in the Frick collection suggest that specimen D856-9 should be referred to Megahippus. Specimen D856-9 matches a deciduous dentition in the AMNH (field number ESP 399-1842) of Megahippus from the Pojoaque Member of the Tesuque Formation. The eroded symphysis of specimen D856-9 was probably strongly upturned, which suggests Megahippus affinities: the more complete jaw from New Mexico (ESP 399-1842) has a strongly upturned symphysis. The New Mexico specimen of Megahippus has a short diastema, strong $\mathrm{dP}_{1}$, and lacks lingual cingula on the $\mathrm{dP}_{2-4}$, as does specimen D856-9. The height of the $M_{1}$ metaconid of specimen D856-9 is greater than that of $H$. affinis. Webb (1969, p. 77) notes that the metaconid on the unworn $M_{1}$ of $H$. affinis is $15 \mathrm{~mm}$ high; on specimen D856-9 it is $19.4 \mathrm{~mm}$ high. Thus, the teeth of specimen D856-9 are the same length but higher crowned than those of $H$. affinis.

The deciduous dentition found in the Browns Park cannot at present be allocated to any previously named species of Megahippus.

\section{Genus PARAHIPPUS Leidy \\ Parahippus cf. P. leonensis Sellards \\ Table 9, Figure 10}

Parahippus leonensis Sellards (1916, p. 83-87, pl. 11, figs. $3,6-9,12$ ).

Holotype.-FGS 5084, right upper cheek tooth, probably $\mathrm{M}^{1}$.

Referred material.-D857-1: crushed skull with $\mathrm{RI}^{2-3}, \mathrm{LI}^{3}, \mathrm{R}$ and $\mathrm{L}$ canine, $\mathrm{RP}^{2-3}, \mathrm{R}$ and $\mathrm{LM}^{1-3}$.

Distribution and age.-Thomas Farm, Griscom Plantation, Tallahassee, Alum Bluff, and Chattahoochee faunas, all in Florida; Hemingfordian land mammal age.

Description.-The skull is highly eroded with many of the cranial features destroyed. It is long and narrow.

\footnotetext{
${ }^{3}$ The Burge fauna was considered Clarendonian by Wood and others (1941) and Webb (1969). Recently, the Burge fauna has been placed in the latest Barstovian (Tedford, R. H., and others, unpub. data, cited in Skinner and Johnson, 1984).
}

TABLE 9.-Skull and dental measurements of Parahippus cf. P. leonensis (specimen D857-1) from locality D857 in the Elk Springs 15-minute quadrangle, Moffat County, Colorado [Measurements in millimeters]
Distance from anterior edge of orbit to nasal tubercle....... 155.0
Height of infraorbital foramen above alveolar border......... 28.5
Width of palate between canines... 26.4 Width of palate between $\mathrm{M}^{3}$...... 35.5
$I^{3}-C$ diastema................ 14.0
C-P ${ }^{1}$ diastema................. 37.5
Length $p^{2-4} \ldots \ldots \ldots \ldots \ldots \ldots \ldots . \ldots 53.5$
Length $M^{1-3} \ldots \ldots \ldots \ldots \ldots \ldots \ldots \ldots . \ldots 4.3$
Length $p^{2}-M^{3} \ldots \ldots \ldots \ldots \ldots \ldots \ldots . . \ldots 9.4$
$I^{2}$ APxTR.................... $8.1 \times 6.6$
$I^{3}$ APXTR .................... $7.8 \times 5.9$
C APXTR................... 4.2 $2 \times 3.8$
$P^{2}$ APXTR..................... 18.6x18.0
$\mathrm{P}^{3}$ APXTR.......................17.1 18.7
$M^{1}$ APXTR ................... 14.1 $1 \times 21.1$

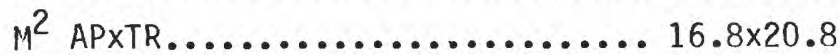

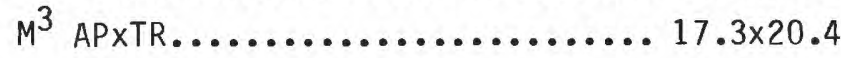

Anteriorly, the premaxillaries are preserved. The incisive foramen, present between and dorsal to the alveoli for the first two incisors, is anterior to a small tubercle situated in the anterior opening of the narial cavity. Ventrally are remnants of the palatine processes of the premaxillaries. The nasal processes of the premaxillaries are broken approximately at their sutures with the nasals. The infraorbital foramen lies above the anterior moiety of the $\mathrm{P}^{4}$. Mesial to the molars, palatine grooves are preserved on the palatine processes of the maxillaries. The anterior edge of the U-shaped posterior nares is opposite the anterior edge of the $\mathbf{M}^{2}$. Posteriorly, and forming two small tubercles on either side of the narial opening, are remnants of the pterygoid hamuli.

The skull is broken posterior to the basisphenoid. The temporal condyle and part of the glenoid cavity of the temporal are preserved. Owing to crushing, the malar part of the zygomatic arch is slightly flared out in the region of the facial crest. 

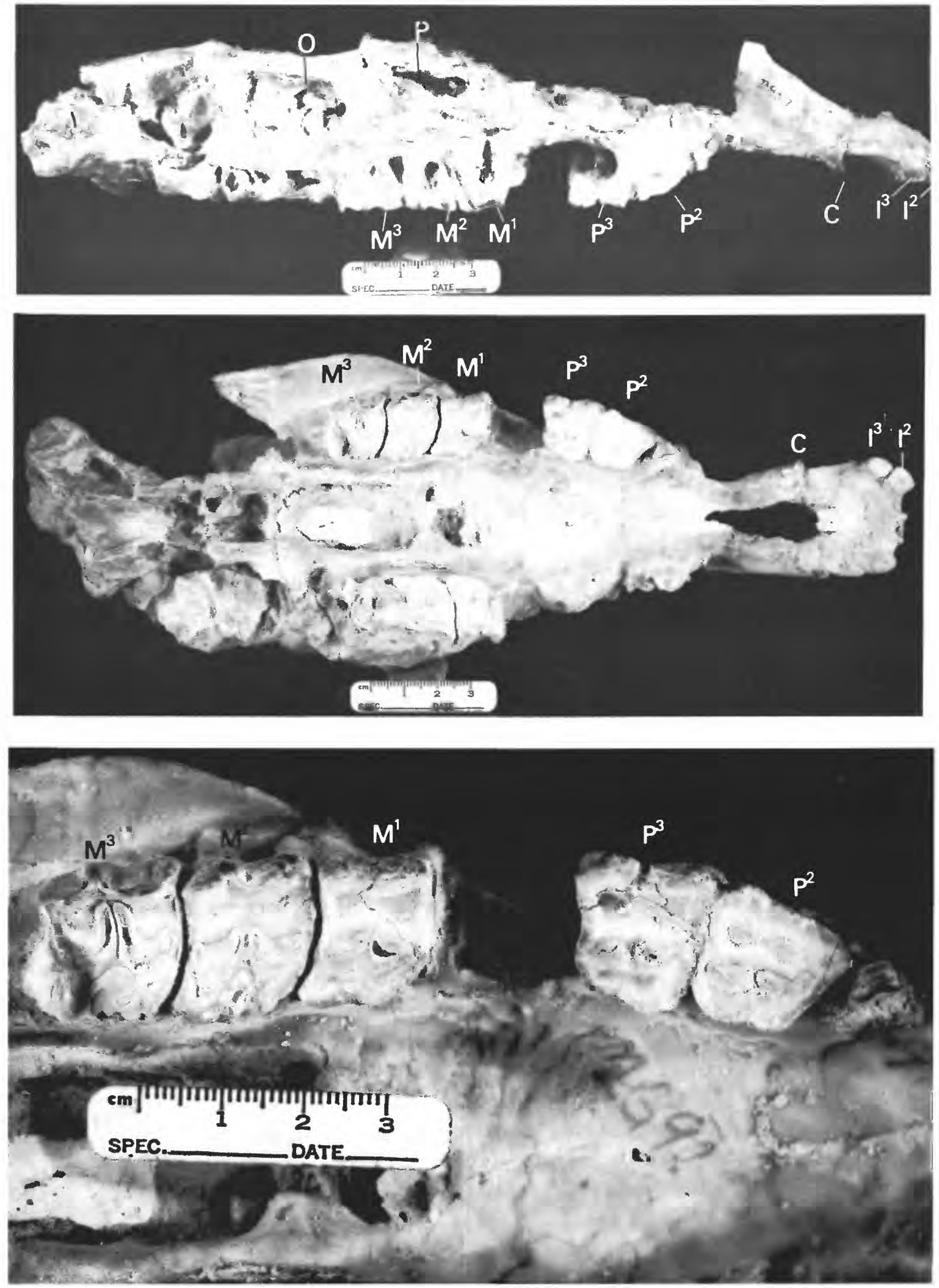

Figure 10.-Parahippus cf. P. leonensis, specimen D857-1, from locality D857, Elk Springs 15-minute quadrangle, Moffat County, Colo. Top, lateral view of right side of skull showing incisors $\left(\mathrm{I}^{2-3}\right)$, canine $(\mathrm{C})$, premolars $\left(\mathrm{P}^{2-3}\right)$, and molars $\left(\mathrm{M}^{1-3}\right)$; $\mathrm{O}$, orbit; $\mathbf{P}$, preorbital fossa. Middle, palatal view of skull. Bottom, closeup view of right $\mathrm{P}^{2-3}, \mathrm{M}^{1-3}$. 
Although partially crushed, the bones of the orbital region reveal significant details. Anteriorly, the facial portion of the lacrymal is depressed, forming the preorbital fossa. The orbital and facial portions of the lacrymal are separated by the preorbital bar, which has a distinct tubercle on its anterodorsal margin. On the orbital surface is a small foramen mesial, and slightly ventral, to a larger lacrymal foramen. The nasolacrymal duct leads forward from the lacrymal foramen and passes beneath the wall of the preorbital fossa. Examination of some skulls of Merychippus in the American Museum of Natural History, collected from the middle part (Skinner and others, 1977) of the Sheep Creek Formation (Matthew and Cook, 1909), reveals that the small foramen below the lacrymal foramen apparently passes anteriorly and mesially into the maxillary sinus. This lower foramen was not seen on modern horse skulls. At the same position in the modern horse is the depression for the origin of the obliquus oculi inferior muscle. On the Sheep Creek horses, the lower foramen is probably too deep to serve as a muscle origin. The foramen is not a second opening into the naso-lacrymal canal as it is in the tapir, in which it merges with the upper naso-lacrymal canal and empties into the nares. On the Sheep Creek horses, this smaller foramen passes medially as well as anteriorly and would not merge with the lower lacrymal duct to exit in the region of the external nares. Possibly, one of the branches of the maxillary part of the trigeminal nerve enters the maxillary sinus through this foramen. According to Getty (1975, p. 655), "small caudal maxillary alveolar branches [of the infraorbital branch of the maxillary branch of the trigeminal nerve] are given off in the pterygopalatine fossa, pass through small foramina in the maxillary tuber and supply the caudal molar teeth and the maxillary sinus. The middle maxillary alveolar branches are given off in the infraorbital canal and constitute the chief nerve supply to the cheek and the maxillary sinus." Because this foramen on the Sheep Creek horses courses into the maxillary sinus, it possibly carried the posterior or middle alveolar nerve.

A small sphenopalatine foramen is present $34 \mathrm{~mm}$ posterior to the preorbital bar and midway up the mesial wall of the orbit. The large vacuity for the optic foramen is $22 \mathrm{~mm}$ posterior to the sphenopalatine foramen. Ventrally, the optic foramen is separated by a sharp ridge of bone from the smaller orbital foramen. The foramen rotundum lies ventral and slightly posterior to the latter. A small supraorbital foramen is present on the dorsal margin of the orbit. On the dorsal surface of the parietal, a crest curves mesially and posteriorly from a small supraorbital tuberosity located above the supraorbital foramen. The frontal-parietal suture is apparent down the midline.

The incisors are worn nearly to their roots, and their occlusal surfaces are flat with centrally located, narrow lakes. The $I^{3}$ is more transversely compressed and smaller than the $\mathrm{I}^{2}$. A short diastema separates the $\mathrm{I}^{3}$ from the small, peglike canine. A longer diastema separates the canine from the $\mathrm{P}^{1}$, which apparently has two closely appressed roots.

The cheek teeth are worn nearly to the roots, and the diagnostic occlusal pattern is nearly obliterated. The $\mathrm{P}^{2}$ is subtriangular and anteroposteriorly longer than wide. The prominent mesostyle is much larger than the diminutive metastyle. Owing to wear, the pre- and postfossettes are flattened ovals near the lingual side of the crown; consequently, the ectoloph is broad. The borders of the lophs are smooth, owing to destruction of the plications. At this stage of wear the protocone and hypocone are indistinctly separated by a small medivallum. The hypocone is larger than the protocone. Labially, two widely separated roots are visible. The $\mathrm{P}^{3}$ is transversely elongated with the buccal side wider than the lingual. The parastyle and metastyle are subequal in size, and the parastyle slightly overlaps the metastyle of the $\mathrm{P}^{2}$. The fossettes are nearly obliterated. The protocone is larger and more mesially projecting than the hypocone, and the posterolingual border of the tooth is reduced in relation to the anterolingual border. In contrast, the anterolingual borders of the molars are reduced in relation to the posterolingual borders. The $\mathrm{P}^{4}$ is missing.

The $\mathrm{M}^{1-2}$ are transversely elongate and posteriorly concave. The transverse elongation is due to the anteroposterior length decreasing toward the root and the transverse width remaining constant. Being less worn, the $\mathrm{M}^{3}$ is less transverse than the $\mathrm{M}^{1}$ or $\mathrm{M}^{2}$. The molar parastyles are prominent and overlap the preceding metastyles. Ribs are only faintly expressed between the styles. The mesostyles are larger than the parastyles, which are larger than the metastyles. Ectocingula run along the base of the teeth and are confluent with the styles. Wear has simplified the molar occlusal patterns, resulting in the loss of the plicaballinae. The $\mathrm{M}^{3}$ retains a small pli-hypostyle on the post-fossette and has a hypoconal groove which extends nearly to the post-fossette. The teeth are worn so that the buccal edges are higher than the lingual edges. The molars have long, widely flaring roots and buccal coatings of cement. The $\mathrm{M}^{3}$ is less worn than the other teeth and has better preserved buccal cement.

Comparisons and discussion.-Comparisons with other horses are difficult owing to the old age of the individual and the crushing and erosion of the skull. In 
size and morphology, however, the worn dentition of specimen D857-1 compares most favorably with those of advanced species of Parahippus and primitive species of Merychippus. Merychippus and advanced species of Parahippus have cementum on the teeth. Downs (1956, table 9) suggested that the thickness of this coating is useful in distinguishing between Merychippus and Parahippus; according to his comparison, the amount of cement on the teeth of advanced Parahippus is less than that on the teeth of two of the most primitive species of Merychippus, $M$. primus and $M$. gunteri. Simpson (1932, p. 23), however, noted that some of the $P$. leonensis from the Thomas Farm quarries in Florida "have as much cement as the less coated Midway [fossil quarries in Florida] $M$. gunteri specimens" and White (1942, p. 22) noted that $P$. leonensis occasionally has more cement than on $M$. primus.

Specimen D857-1 has less cement on the buccal side of the teeth than some Merychippus from the Sheep Creek Formation (Matthew and Cook, 1909) of late Hemingfordian age. The amount of cement on specimen D857-1 is similar to that on $P$. avus (Marsh, 1874) $(=P$. brevidens (Marsh, 1874) according to Downs (1956, p. 240)) and also to that on $P$. leonensis Sellards, 1916. The type of $P$. avus is similar in size to specimen D857-1; on the type of $P$. brevidens the $\mathrm{M}^{3}$ is equal in size and the $\mathbf{M}^{2}$ is larger than that of specimen D857-1. The amount of cement on specimen D857-1 is equal to that on the type of $P$. avus. A partial skull of $P$. avus (AMNH 14182) illustrated by Osborn (1918, pl. 6) has no features preserved useful for comparison with specimen D857-1. P. leonensis is slightly smaller than $P$. avus. Downs (1956, table 6) listed statistics on the lengths and widths of the cheek teeth of $P$. avus and $P$. leonensis; for length and width, specimen D857-1 falls nearer the means for $P$. leonensis. Downs (1956, p. 243) noted that $P$. avus and $P$. leonensis are similar in the amount of cement present on the teeth.

$P$. crenidens (Scott, 1893), and $P$. coloradensis Gidley, 1907, also have cement on the teeth. According to Downs (1956, table 9), $P$. crenidens has less cement than $P$. avus and, therefore, the cement is also less than on specimen D857-1. Downs (1956, table 9) characterized $P$. coloradensis as having only a light coat of cement. In the original diagnosis of $P$. coloradensis, no mention of cement was made by Gidley; Gazin (1932, p. 77) referred some teeth from Skull Spring, Oreg., to this species, noting that they lack cement.

The size of the teeth and the amount of cement on them closely matches that of $P$. leonensis, although the difference with $P$. avus is not great. For this reason, specimen D857-1 is assigned to Parahippus cf. $P$. leonensis.

\author{
Order ARTIODACTYLA Owen \\ Suborder TYLOPODA nliger \\ Family CAMELIDAE Gray \\ Subfamily STENOMYLINAE Matthew \\ Genus BLICKOMYLUS Frick and Taylor \\ Blickomylus galushai Frick and Taylor \\ Table 10, Figure 11
}

Blickomylus galushai Frick and Taylor (1968, p. 23-36, figs 8-11).

Holotype.-F:AM 50840, a nearly complete skull with $\mathrm{I}^{1}-\mathrm{M}^{3}$, from Blick Quarry in the Chamisa Mesa Member of the Zia Sand of Galusha (1966), in Sandoval County, N. Mex.

Referred material.-D857-2,- $\mathrm{LP}^{4}, \mathrm{LM}^{1-2}, \mathrm{LP}_{4}$; D857-3, distal fragment right radius-ulna; D857-4, proximal fragment right metacarpus; D857-5, fragmentary distal metapodial.

Distribution and age.-Chamisa Mesa Member of Galusha (1966) and Cañada Pilares Member of Gawne (1981b) of the Zia Sand of Galusha (1966); Arikaree Formation, Fremont County, Wyo.; Browns Park Formation, Moffat County, Colo.; Hemingfordian land mammal age.

Description.-The $\mathrm{P}^{4}$ is small and heavily worn, and the fossette between the buccal and lingual cusps has disappeared. The $\mathrm{M}^{1}$ is short and transversely narrow and tapers strongly antero-posteriorly toward the roots. The pre- and post-fossettes are present as shallow depressions lacking internal enamel rings. Ribs and styles are absent on the flat buccal wall, and the posterior lobe of the tooth is longer than the anterior lobe. The $\mathrm{M}^{2}$ is transversely narrow and hypsodont with only the the anterior lobe completely preserved. A fossette is present on this lobe. Except for a faint parastyle, the buccal wall is smooth. On the $\mathbf{M}^{1}$ and

TABLE 10.-Dental and skeletal measurements of Blickomylus galushai from locality D857, Elk Springs 15-minute quadrangle, Moffat County, Colorado

[Measurements in millimeters]

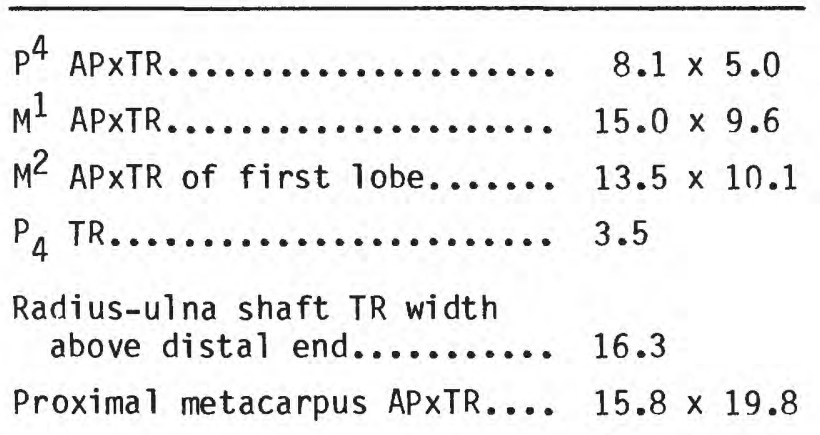



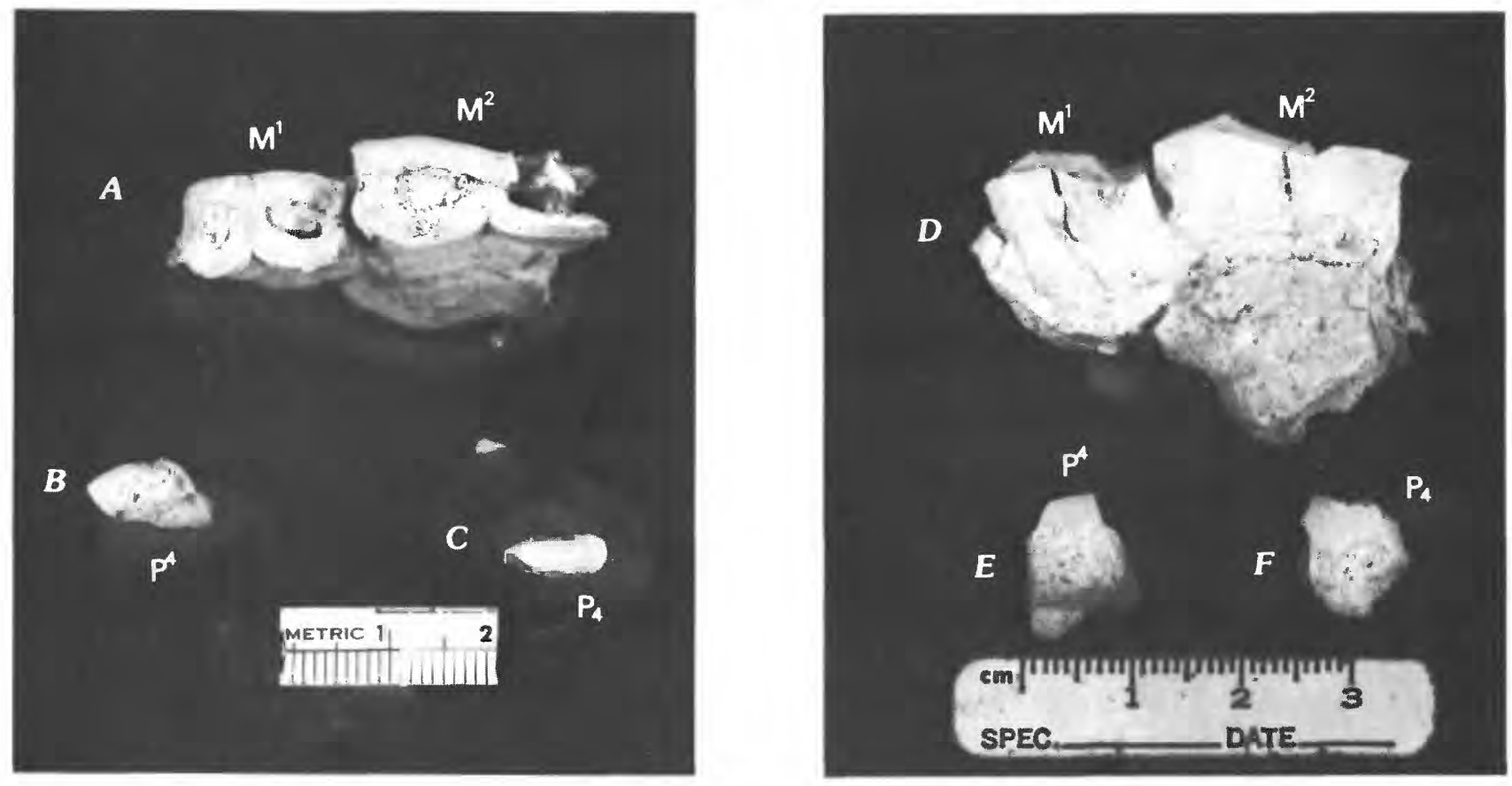

Figure 11.-Blickomylus galushai, specimen D857-2, from locality D857, Elk Springs 15-minute quadrangle, Moffat County, Colo. Left photo: $A$, occlusal view of left molars $\left(\mathrm{M}^{1-2}\right) ; B$, occlusal view of left premolar $\left(\mathrm{P}^{4}\right) ; C$, occlusal view of left $\mathrm{P}_{4}$. Right photo: $D$, lingual view of left $\mathrm{M}^{1-2} ; E$, buccal view of left $\mathrm{P}^{4} ; F$, buccal view of left $\mathrm{P}_{4}$. Both scales in centimeters.

$\mathrm{M}^{2}$ the wall of the metaconule is flatter and does not project as far lingually as does the wall of the protocone. The $\mathrm{P}_{4}$ is compressed laterally and tapers markedly anteriorly. It lacks a paraconid inflection.

The shaft of the distal part of the radius-ulna is relatively slender. Only half of the distal end is preserved. The lunar and cuneiform condyles are subequal in size, and the lunar condyle has a proximolaterally trending trough on its medial side. Anteriorly, the lateral and medial carpal extensor grooves are present, the medial groove being deeper and narrower than the lateral. A prominent tuberosity lies between them. Anterodorsal to the cuneiform condyle is a distal interosseous foramen. A posterior distal interosseous foramen is also present with a vertical groove extending approximately $20 \mathrm{~mm}$ proximally. The lateral surface of the shaft immediately above the cuneiform condyle is highly rugose.

The proximal metacarpal preserves the trapezoid, magnum, and unciform facets. Rugose depressions for metacarpals 2 and 5 are present posteriorly beneath the trapezoid and unciform facets respectively. Metacarpals 3 and 4 are completely fused proximally.

Comparisons and discussion.-The narrow, hypsodont teeth with smooth buccal walls clearly identify this camel as a member of the subfamily Stenomylinae. Direct comparisons of many specimens, including the types of Blickomylus and Rakomylus, establish that the Browns Park stenomyline is a Blickomylus. Both specimen D857 and Blickomylus differ from most Stenomylus in having more solidly fused metacarpals. The metacarpals are completely uncoossified on $S$. hitchcocki Loomis, 1910, and on an unnamed Stenomylus from Wellton, Ariz. In S. gracilis Peterson, 1906, the proximal halves of the third and fourth metacarpals are fused, but the line of fusion is usually very prominent, as in the type. On specimen D857-4 and Blickomylus, this line of fusion is very faint. A few specimens of Stenomylus though, such as F:AM 36815 (Frick and Taylor, 1968, fig. 6), have strongly coossified metacarpals which resemble those of Blickomylus. The $\mathrm{P}^{4}$ of specimen D857-2 and Blickomylus is more reduced than that of Stenomylus. The length of the $\mathrm{P}^{4}$ of specimen D857-2 is $8.1 \mathrm{~mm}$; that of Blickomylus ranges from 7.8 to $9.0 \mathrm{~mm}$. The length of the $\mathrm{P}^{4}$ of $S$. gracilis ranges from 10.0 to $10.3 \mathrm{~mm}$. Although the length of the $\mathrm{P}^{4}$ of the Wellton Stenomylus is the same as that of specimen D857-2, the $\mathrm{P}^{4}$ of the Wellton camel is $2 \mathrm{~mm}$ wider. The molars of the Wellton Stenomylus are shorter than those of specimen D857-2 
and Blickomylus. Similarly, though the molars of $S$. gracilis have the same length as those of specimen D857-2 and Blickomylus, the $\mathrm{P}^{4}$ is longer.

The crown patterns and tooth sizes of specimen D857-2 match those on some Blickomylus from the Chamisa Mesa Member of the Zia Sand and differ significantly from those of Rakomylus. Both specimen D857-2 and Blickomylus differ from Rakomylus in having a relatively larger $\mathrm{M}^{1}$. The $\mathrm{M}^{1}$ of Rakomylus is $9.3 \mathrm{~mm}$ long (Frick and Taylor, 1968, table 6), whereas that of Blickomylus ranges from an estimated $10 \mathrm{~mm}$ to $17.5 \mathrm{~mm}$ (Frick and Taylor, 1968, table 4); specimen D857-2 measures $15.0 \mathrm{~mm}$. The $\mathrm{P}^{4}$ of specimen D857-2 also lies within the size range of Blickomylus given by Frick and Taylor, and is larger than the $\mathrm{P}^{4}$ of Rakomylus. Also, the concave wear facets on the anterior lobes of the two teeth match those on Blickomylus.

The metacarpal of Rakomylus is about 30 percent shorter than that of Blickomylus, but the metacarpal of specimen D857-2 is too incomplete to offer any information about size. However, the dental evidence is conclusive that this camel is Blickomylus. The only known species of Blickomylus is B. galushai. The Browns Park camel cannot be distinguished morphologically or metrically from $B$. galushai and is therefore assigned to that species.

\section{Subfamily CAMELINAE Gray Tribe PROTOLABIDINI Cope \\ Genus of. PROTOLABIS Cope}

Table 11, Figure 12

Referred material.-D856-17, distal fragment left humerus; D856-18, distal fragment left humerus; D856-19, distal fragment right humerus; D856-20, proximal fragment left radius-ulna; D856-21, proximal left radius-ulna; D856-22, proximal fragment left radius-ulna; D856-23, proximal fragment right radiusulna; D856-24, distal fragment right radius-ulna; D856-25, distal fragment left radius-ulna; D856-26, distal fragment left radius-ulna; D856-27, distal fragment left tibia; D856-28, left astragalus; D856-29, left astragalus; D856-30, left astragalus; D856-31, left astragalus; D856-32, right astragalus; D856-33, right calcaneum; D856-34, right proximal fragment calcaneum; D856-35, left calcaneum; D856-36, left calcaneum; D856-37, left distal fragment calcaneum; D856-38, right proximal fragment metatarsal; D856-39, right proximal fragment metatarsal; D856-40, right proximal fragment metatarsal; D856-41, distal fragment metapodial; D856-42, distal fragment metapodial; D856-43, distal fragment metapodial; D856-44, proximal phalanx; D856-45, proximal phalanx; D856-46, medial phalanx; D856-47, medial phalanx; D856-48, proximal phalanx; D856-49, proximal phalanx; D856-50, proximal phalanx; D856-51, proximal phalanx.

Comparisons and discussion. - The postcranial elements are practically indistinguishable from those of Protolabis coartatus. The humeri, radii-ulnae, and tibiae are completely within the range of morphological and size variation of that species. The calcanea, astragali, and metapodials of the locality D856 camel are somewhat larger than those of most specimens of $P$. coartatus, but the difference is insignificant-for example, the proximal widths of the metatarsals range from no greater to at most 8 percent wider than the largest known metatarsal of $P$. coartatus. The phalanges from locality D856 are similar in length, but slightly more slender, than those of $P$. coartatus. The anterior limb elements from locality D856 are, like those of the $P$. coartatus specimens from the Milk Creek Formation (Clarendonian) of Arizona, slightly smaller than those of the type of $P$. coartatus.

None of the various limb elements were associated. However, they can be assumed to belong to the same species because of their close match in size and morphology to similar limb elements of $P$. coartatus. Because of this close correspondence, the limbs from locality D856 probably belong to a species of Protolabis, although not necessarily $P$. coartatus. At present, there are few characteristics other than size and proportions, that can be used to separate the postcrania of various genera of Miocene camels. For the sake of completeness, the following comparisons are offered.

The locality D856 camel limb elements are smaller than those of Aepycamelus, Hesperocamelus, Megatylopus, Titanotylopus, Pliauchenia magnifontis, Hemiauchenia, Alforjas, and Procamelus grandis. The limbs of Procamelus occidentalis cannot be adequately compared with those from locality D856. Oxydactylus, Priscocamelus, Miolabis, Nothotylopus, and probably Aguascalientia have unfused metapodials. Tanymykter has unfused metacarpals and only weakly fused metatarsals, in contrast to the strongly fused metapodials of D856. The limb bones of Stenomylus are smaller and the metapodials generally more slender and less coossified than those from locality D856. Frick and Taylor (1968) illustrated the metapodials of Blickomylus and Rakomylus, and they belong to smaller animals than the locality D856 camel (the Blickomylus distal radius from the Browns Park Formation also supports smaller size for these camels). The limbs of Australocamelus, Nothokemas, and Floridatragulus have not been adequately described. Michenia has smaller, slenderer limbs than the locality D856 camel. Thus, 
TABLE 11.-Skeletal measurements of cf. Protolabis sp. from locality D856, Citadel Plateau 15-minute quadrangle, Moffat County, Colorado

[Measurements in millimeters; leaders (---) indicate no data

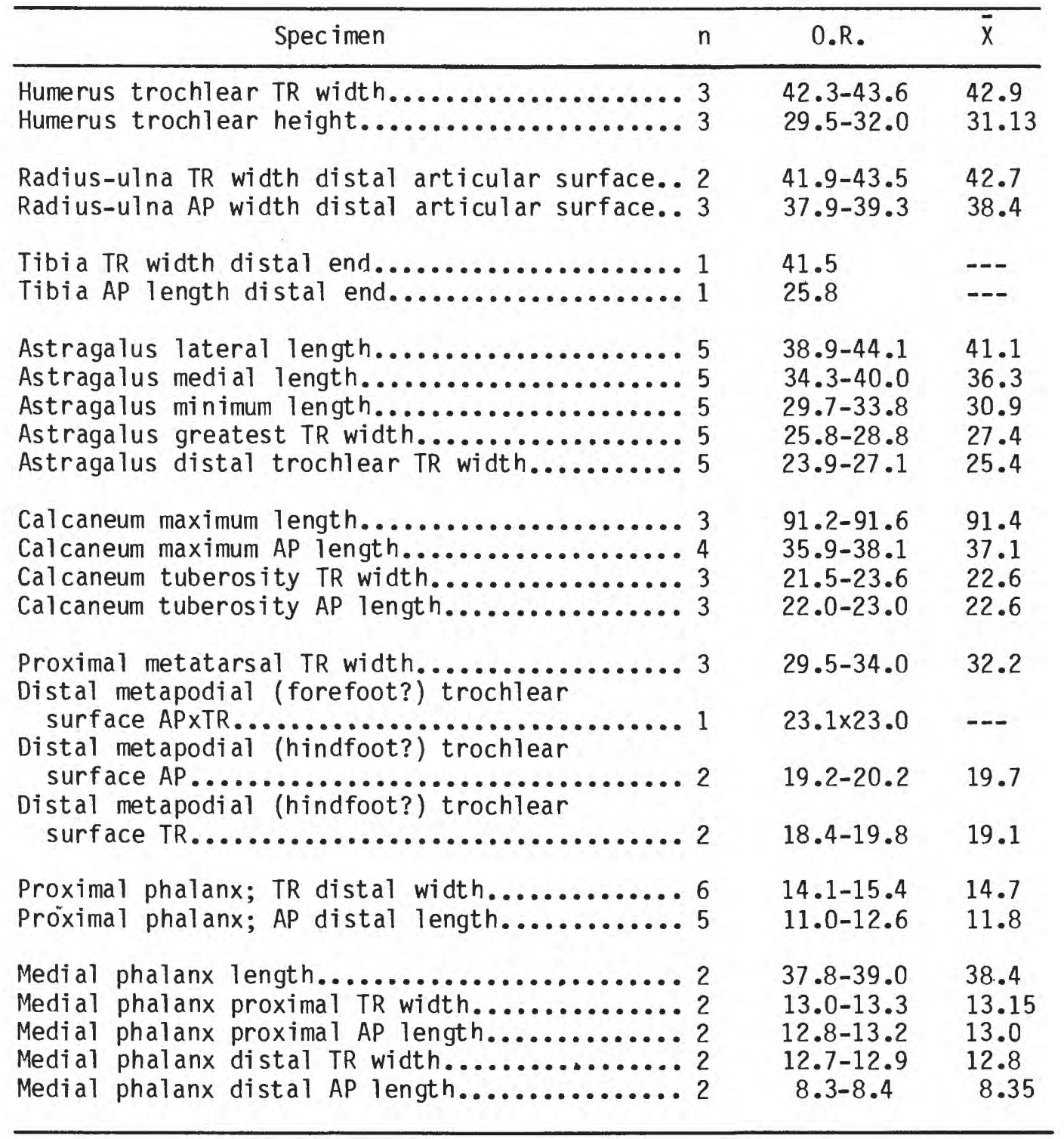

these limb elements probably belong to Protolabis. A thorough study of that genus, however, is necessary before specific assignment of these limbs can be made.

\section{Genus MICHENIA Frick and Taylor Michenia sp. \\ Table 12, Figure 13}

Referred material.-D856-11, $\mathrm{RI}_{2-3}$ roots, $\mathrm{RC}$; D856-12, fragmentary symphysis with $\mathrm{RP}_{1}$; D856-13, right dentary with $\mathrm{P}_{1-4}, \mathrm{M}_{1-2}, \mathrm{M}_{3}$ (broken); D856-14, distal fragment right humerus; D856-15, proximal fragment left radius; D856-16, proximal right metacarpal.

Description.-The $I_{3}$ is the only incisor with the crown preserved. In early wear it is highly spatulate and transversely flattened with a crown $20.2 \mathrm{~mm}$ high. The incisor roots are small. The canine is separated from the $\mathrm{I}_{3}$ by a $4.0 \mathrm{~mm}$ diastema. The canine is small, slightly recurved, and transversely flattened with the buccal side convex and the lingual side concave dorsoventrally. Anterodorsally, a slight pinching of the enamel forms a small flange.

The C- $P_{1}$ diastema is not preserved. The $P_{1}$ is suppressed; that is, although fully formed, the tooth has 


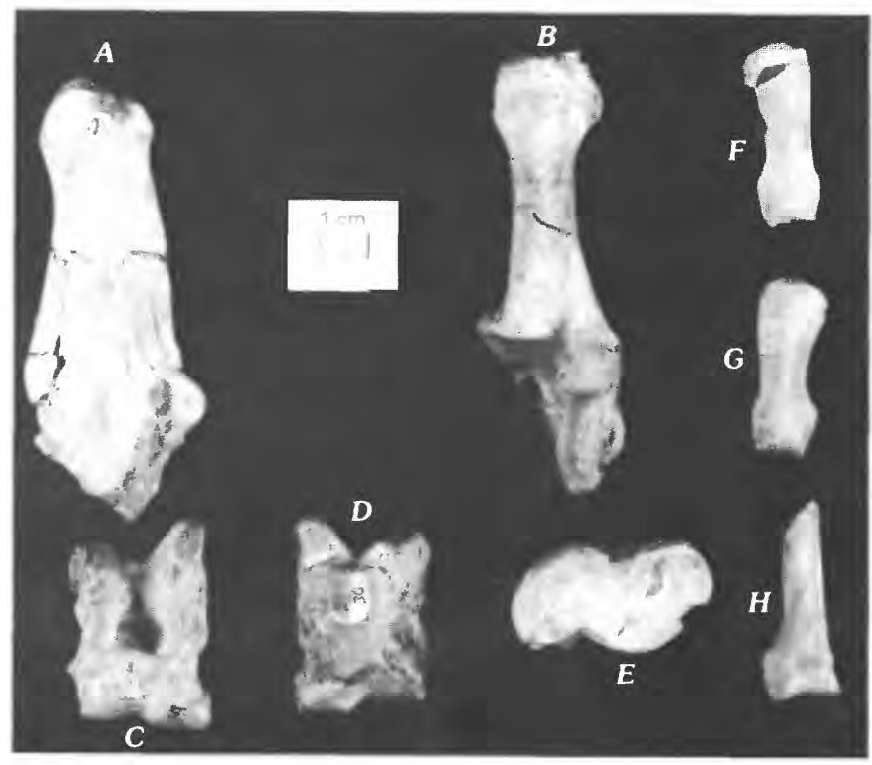

FIGURE 12.-Cf. Protolabis, from locality D856, Citadel Plateau 15-minute quadrangle, Moffat County, Colo. $A$, right calcaneum, lateral view; specimen $\mathrm{D} 856$-33. $B$, left calcaneum, anterior view; D856-36. $C$, left astragalus, anterior view; D856-29. $D$, left astragalus, posterior view; D856-30. $E$, right astragalus, lateral view; D856-32. F, medial phalanx, anterior view; D856-46. $G$, medial phalanx, anterior view; D856-47. $H$, proximal phalanx, anterior view; D856-49.

not erupted in the mature animal. The $\mathrm{P}_{1}$ has only one root; it cannot be determined whether this root formed from a single root or from two fused roots. Excavation of the bone shows that the $P_{1}$ is vertical.

The $P_{2}$ lies $23.5 \mathrm{~mm}$ behind the $P_{1}$. The $P_{2}$ is short and transversely narrow, with the simple crown consisting only of a low protoconid. A shallow median sulcus on the single root indicates that it formed from the fusion of two separate roots. The $P_{3}$ is transversely narrow and double-rooted. The protoconid, swollen at the base, is the most distinctive cusp. A ridge runs anteriorly from the protoconid and terminates in a minute and slightly lingually inflected paraconid. Posteriorly, another ridge terminates in a small but distinct swelling formed from the entoconid and hypoconid. The $\mathrm{P}_{4}$ is transversely narrow and nearly as long as the combined lengths of the $\mathrm{P}_{2}$ and $\mathrm{P}_{3}$. The protoconid is the highest cusp. A lingual sulcus separates the protoconid from the lingually inflected paraconid. The entoconid and hypoconid have, by wear, united to form a posterior swelling as broad as that of the protoconid. A broad, shallow buccal sulcus lies between the protoconid and hypoconid. Wear has eliminated the fossettid between the hypoconid and entoconid.

The $M_{1}$ is worn nearly to the roots. It is relatively long, and the posterior lobe is wider than the anterior lobe. On the $\mathrm{M}_{2}$, wear has eliminated the anterior fossettid, and the posterior fossettid is relatively small. The lingual wall is flat, with only a small parastylid present. The $\mathrm{M}_{3}$ is broken behind the anterior moiety. The worn crown height measures $17.2 \mathrm{~mm}$ on the protoconid. The parastylid is prominent lingually, but the mesostylid is only a low ridge. Lingual ribs are absent. None of the molars have intercolumnar stylids or protostylids.

Erosion has eliminated most of the details of the dentary. The right dentary is narrow transversely $-6.3 \mathrm{~mm}$ wide between the $P_{1}$ and $P_{2}$. The minimal depth of the dentary between the $P_{1}$ and $P_{2}$ is not preserved; however, it is less than the depth at the suppressed $P_{1}$, where it is $22.5 \mathrm{~mm}$.

On the basis of size, three fragmentary limb elements are referred to this camel. The distal fragment of the humerus has the trochlea preserved. Anteriorly, above the medial condyle, is a transverse trough for the origin of the common digital extensor. The proximal fragment of the radius has only the humeral articular surface preserved. The lateral tuberosity is smaller than on cf. Protolabis. The proximal metacarpal preserves the small, triangular trapezoidal facet posteriorly. Anterior to the trapezoidal facet is the large, concave magnum facet, quadrilateral in shape. Below its anterior edge is

TABLE 12.-Dental and skeletal measurements of Michenia sp. from locality D856, Citadel Plateau 15-minute quadrangle, Moffat County, Colorado

[Measurements in millimeters]

\begin{tabular}{|c|c|}
\hline 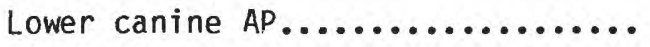 & 6.4 \\
\hline$P_{2}$ APxTR $\ldots \ldots \ldots \ldots \ldots \ldots \ldots$ & $5.0 \times 2.5$ \\
\hline $\mathrm{P}_{3}$ APxTR $\ldots \ldots \ldots \ldots \ldots \ldots \ldots \ldots$ & $8.4 \times 3.4$ \\
\hline$P_{4} A_{P x T R} \ldots \ldots \ldots \ldots \ldots \ldots \ldots$ & $12.7 \times 6.2$ \\
\hline$M_{1}$ APXTR $\ldots \ldots \ldots \ldots \ldots \ldots$ & $20.0 \times 11.0$ \\
\hline$M_{2}$ APxTR $\ldots \ldots \ldots \ldots \ldots \ldots \ldots$ & $23.9 \times 12.9$ \\
\hline$M_{3}$ APxTR of first lobe............ & $13.8 \times 13.6$ \\
\hline Depth jaw between $P_{1}$ and $P_{2} \ldots \ldots$ & $<22.5$ \\
\hline Depth jaw below $P_{1} \ldots \ldots \ldots \ldots \ldots$ & 22.5 \\
\hline Humerus trochlear TR width........ & 33.7 \\
\hline Humerus maximum trochlear height... & 25.3 \\
\hline $\begin{array}{l}\text { Radius; width proximal articular } \\
\text { surface...................... }\end{array}$ & 33.2 \\
\hline
\end{tabular}




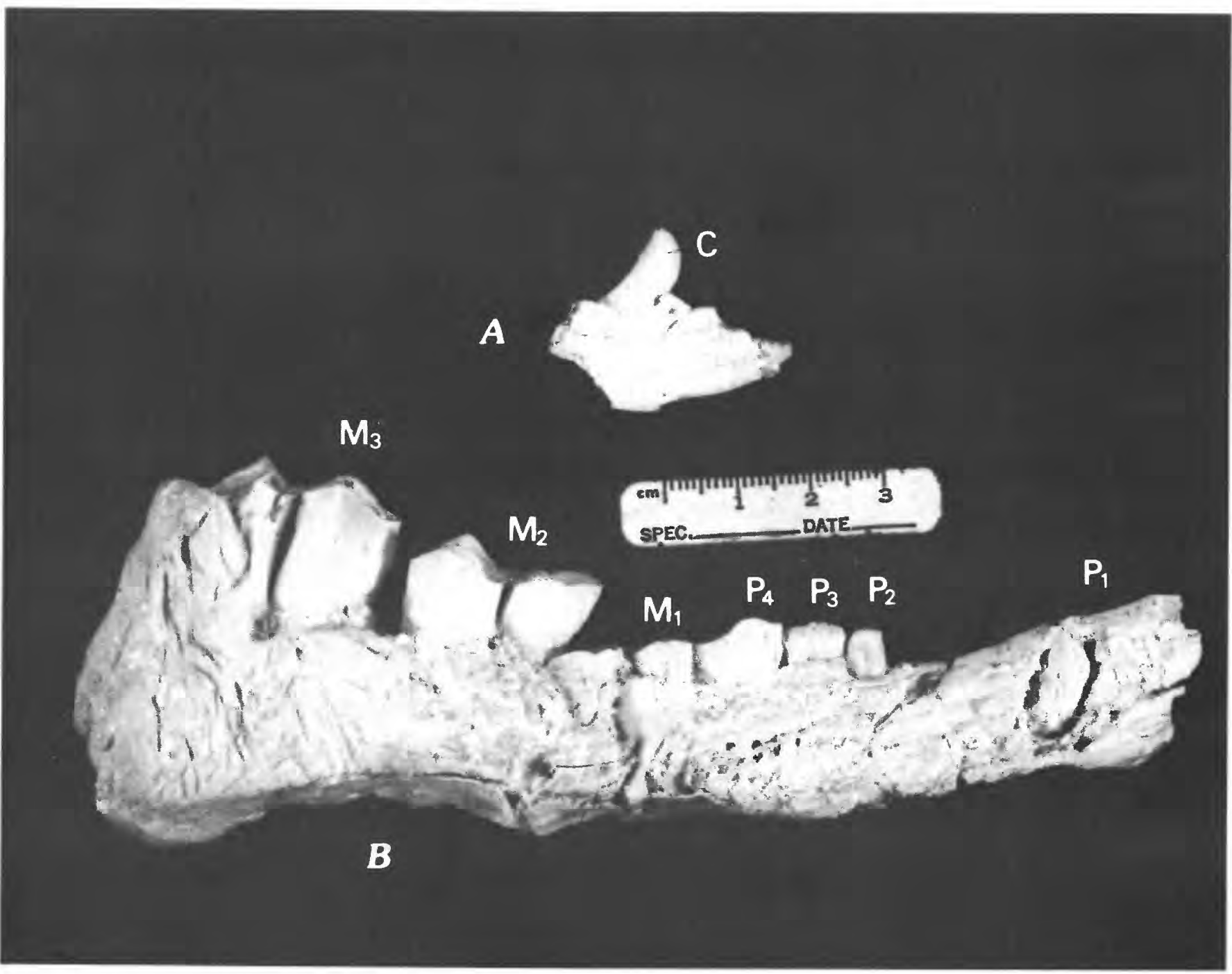

FIGURE 13.-Michenia sp., from locality D856, Citadel Plateau 15-minute quadrangle, Moffat County, Colo. $A$, lateral view of right symphysis with incisor roots and canine $(C)$ of specimen D856-11. B, lateral view of right dentary with premolars $\left(P_{1-4}\right)$ and molars $\left(M_{1-3}\right)$ $\left(\mathrm{M}_{3}\right.$ broken) of specimen D856-13.

a small tuberosity. Only the anterior portion of the unciform facet is preserved. Metacarpals 3 and 4 are completely fused, and the line of fusion is not visible.

Comparisons and discussion.-Specimen D856-13 differs from Oxydactylus, Priscocamelus, Tanymykter and Nothokemas in having higher crowned molars, reduced premolars, and suppressed $\mathrm{P}_{1}$. Reduced premolars and suppressed $\mathrm{P}_{1}$ separate specimen D856-13 from Australocamelus, Aepycamelus, and Hesperocamelus; in addition, the latter two are much larger. Procamelus has relatively nonreduced premolars, fully erupted $\mathrm{P}_{1}$, and more hypsodont molars than specimen D856-13. Miolabis is distinguished from specimen D856-13 by the absence of $P_{1}$, relatively shorter and less laterally compressed premolars, and lower crowned molars with stronger metastylids. Miotylopus is distinguished from specimen D856-13 by rather brachyodont, short molars, and nonreduced premolars. Nothotylopus differs from specimen D856-13 in having more brachyodont molars, larger $P_{3}$ with well-defined cusps, absent $P_{2}$, and erupted $P_{1}$. Low-crowned molars, nonreduced premolars, and $\mathrm{P}_{2-3}$ diastema distinguish Floridatragulus from specimen D856-13. Aguascalientia is much smaller than D856-13, with non-reduced $\mathrm{P}_{2-3}$, and with brachyodont, laterally swollen molars with intercolumnar tubercles on $\mathrm{M}_{1-2}$. The stenomylines possess extremely hypsodont and flat-walled molars. Hemiauchenia 
lacks the $\mathbf{P}_{2}$ and has so-called llama buttresses on the lower molars; Paleolama has low-crowned molars with strong mesostylids.

Pliauchenia magnifontis Gregory, 1942 is larger than specimen D856-13 and has a large and erupted $P_{1}$; the $P_{2-4}$ are longer and broader than on specimen D856-13. Pliauchenia singularis Matthew, 1918 differs from specimen D856-13 in having broader $P_{3-4}$, shorter molars, and $\mathrm{M}_{2-3}$ with prominent parastylids. Specimen D856-13 cannot adequately be compared with Pliauchenia minima Wortman, 1898, as it has never been illustrated, and measurements were not given in the original description. Gregory $(1942, \mathrm{p}$. 379$)$ noted that $P$. minima "looks about as much like an antelope as a camelid ***and cannot be definitely assigned to any family at present." Specimen D856-13 differs from Pliauchenia humphreysiana Cope, 1875, Protolabis heterodontus (Cope, 1874), and Protolabis barstowensis Lewis, 1968, in having a small canine and suppressed $P_{1}$. These same criteria separate D856-13 from most individuals of Protolabis coartatus (Stirton, 1929), although a few individuals of $P$. coartatus have a suppressed $P_{1}$.

Specimen D856-13 resembles Michenia in possessing a small, semiincisiform lower canine and differs from Protolabis which possesses a larger, caniniform canine. The sizes of the lower canines in Michenia and Protolabis do not overlap (Honey and Taylor, 1978, p. 418). Specimen D856-13 resembles derived forms of Michenia in having a suppressed $\mathrm{P}_{1}$. Although not restricted to Michenia, suppression of the $P_{1}$ is much more common in that genus than in Protolabis, in which it is only known to occur in a few individuals of the derived $P$. coartatus.

Reduction in size of the premolars occurs in Michenia and Protolabis, and is greatest in Protolabis coartatus and Michenia yavapaiensis Honey and Taylor, 1978. The size of the $P_{2}$ and $P_{3}$ of specimen D856-13 is close to the mean size given for Michenia yavapaiensis, and is further removed from the mean size for Protolabis coartatus (Honey and Taylor, 1978, tables 4 and 10). The $\mathrm{P}_{4}$ however, is relatively long and is closer to the mean length for Protolabis coartatus than for Michenia yavapaiensis, although it falls within the observed range of the latter species. Fracturing has lengthened the $\mathrm{M}_{1}$ of specimen D856-13 slightly, but nevertheless it is closer to the mean length of $P$. coartatus than to $M$. yavapaiensis. The $\mathrm{M}_{2}$ length (but not width) is closer to the mean length of $P$. coartatus, but it also falls within the observed range of $M$. yavapaiensis.

The ramal depth of Michenia is less than that of Protolabis. The ramal depth at $P_{1}$ of specimen D856-13 is $22.5 \mathrm{~mm}$, which is intermediate between average ramal depths for currently recognized species of Michenia and Protolabis.
Although some of the above characteristics are equivocal, the small canine and suppressed $P_{1}$ indicate that the material from locality D856 belongs to Michenia. The limb elements are referred to this genus because they cannot be separated from those of Michenia yavapaiensis. The reduced premolars and suppressed $\mathrm{P}_{1}$ exclude this specimen from $M$. agatensis Frick and Taylor, 1971; the D856 camel is distinct from M. exilis (Matthew and Macdonald, 1960) in having a suppressed $P_{1}, P_{2-3}$ reduced relative to $P_{4}$, more elongate molars, and fused metapodials. The depth of the jaw is greater than in Michenia yavapaiensis, and the lengths of the $\mathrm{P}_{4}-\mathrm{M}_{2}$ lie at the extremes of the observed ranges of these teeth in Michenia yavapaiensis. For these reasons, this small camel from locality D856 is not included within Michenia yavapaiensis. It may be a representative of a new species, but a larger sample is needed before this can be verified.

\section{Subfamily CAMELINAE or AEPYCAMELINAE Procamelus sp. or Aepycamelus sp. Table 13, Figure 14}

Referred material.-D855-1, right ramus with $\mathrm{dI}_{2-3}$, $\mathrm{I}_{1}$ (?), $\mathrm{dC}, \mathrm{dP}_{3-4}, \mathrm{M}_{1} ; \mathrm{D} 855-2$, right astragalus; D856-52, right distal fragment humerus; D856-53, left distal fragment humerus; D856-54, right proximal fragment radius-ulna; D856-55, right distal fragment radius-ulna; $\mathrm{D} 856-56$, left astragalus; $\mathrm{D} 856-57$, right lunar, D856-58, right scaphoid; D856-59, right cuneiform; D856-60, distal fragment metapodial; D856-61, distal fragment metapodial; D856-62, distal fragment metapodial; D856-63, distal fragment metapodial; D856-64 through D856-72, eight proximal phalanges; D856-73, medial phalanx; D856-74, medial phalanx; D856-88, medial phalanx.

Description.-The spatulate $I_{1}$ is in the process of eruption. It lies beneath the broken, slightly anteroposteriorly flattened root of $\mathrm{dI}_{2}$. The laterally flattened root of $\mathrm{dI}_{3}$ follows a diastema of $7.5 \mathrm{~mm}$. The broken root of $\mathrm{dC}$ is directed anteriorly.

The mandible is broken $26 \mathrm{~mm}$ behind the deciduous canine and $23 \mathrm{~mm}$ in front of the $\mathrm{dP}_{3}$, and the jaw length between these two teeth is not measurable. A fragment from the left side of the jaw contains the roots of the $\mathrm{dP}_{2}$, and (18 mm anteriorly) the alveolus for the $\mathrm{P}_{1}$ (camels lack a deciduous predecessor to the $\mathrm{P}_{1}$, according to Frick and Taylor, 1968, p. 14). The $\mathrm{dP}_{3}$ is long, narrow, and double-rooted, consisting of three cusps consecutively wider posteriorly; the third cusp is much wider than the preceding two. Buccally, two sulci separate the three cusps, and the posterior sulcus is wider than the anterior sulcus. On the lingual side of 
TABLE 13.-Dental and skeletal measurements of Procamelus sp. or Aepycamelus sp. from localities D855 and D856, Citadel Plateau 15-minute quadrangle, Moffat County, Colorado, and comparative measurements on Aepycamelus from the Pojoaque Member of Galusha and Blick (1971) (late Barstovian and possibly early Clarendonian) of the Tesuque Formation [Measurements in millimeters; leaders (--) indicate no data. F:AM-Frick, American Museum numbers]

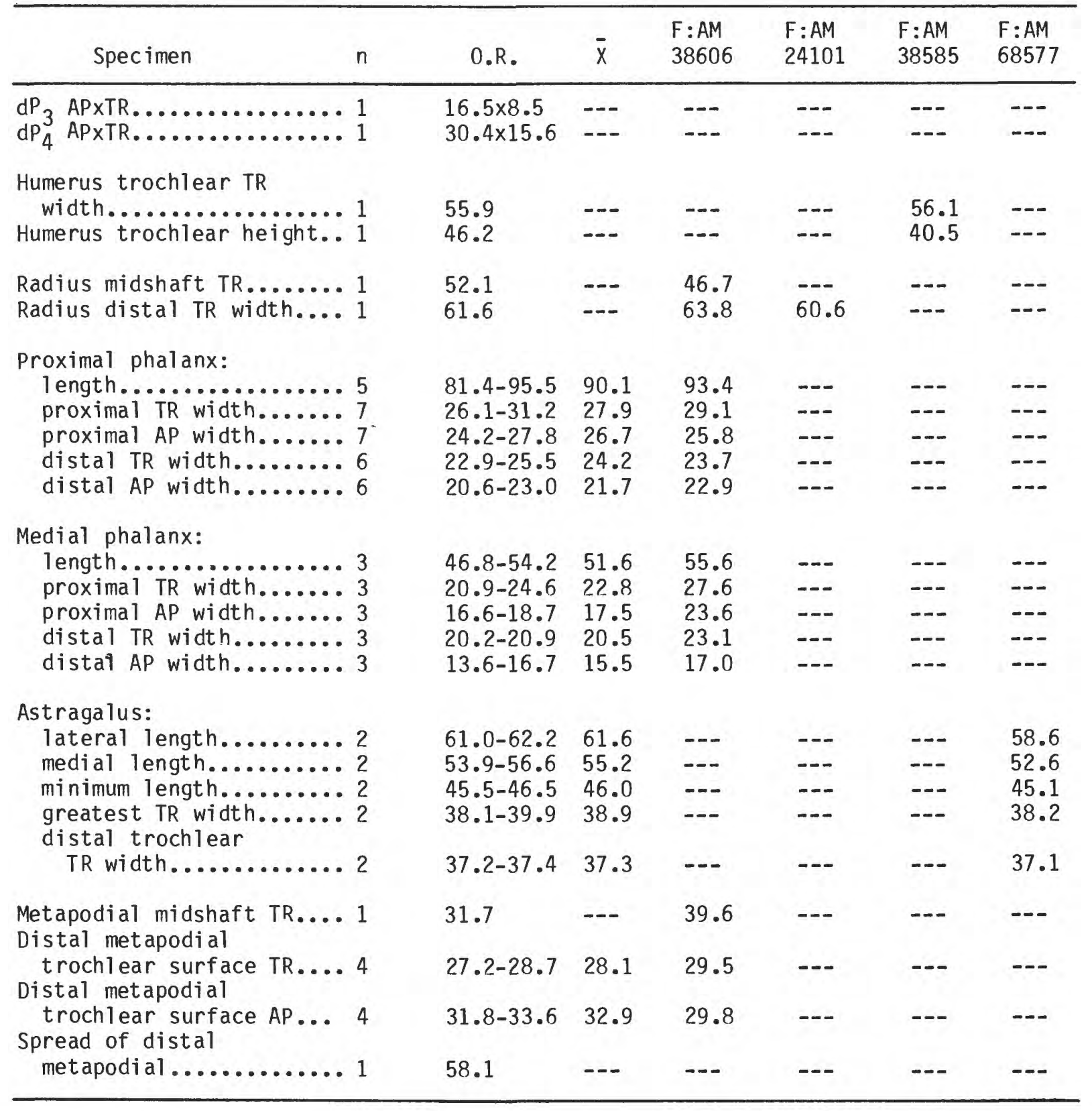

the tooth is a narrow, anterior sulcus. Owing to wear, all traces of fossettids have been eliminated.

The $\mathrm{dP}_{4}$ is three-lobed with the posterior lobe widest. A small tubercle is present in the anterior buccal sulcus between the first two lobes. Formed as a small fold on the posterior wall of the first lobe, the tubercle disappears before reaching the base of the crown. Traces of ribs are preserved on the lingual walls of the second and third lobes, and a small stylid is present between the first and second lobes. Wear has eliminated all fossettids.

The second lobe of the $M_{1}$ is broken. Although the tooth is in wear, the prefossettid is still present. An intercolumnar tubercle is present between the protoconid and hypoconid near the base of the tooth. Lingually, the parastylid and mesostylid are prominent. The metaconid is $25.4 \mathrm{~mm}$ high and has a faint rib. The $\mathrm{M}_{2}$ is fragmentary, revealing nothing diagnostic. The unerupted $\mathrm{M}_{3}$ is lost. 

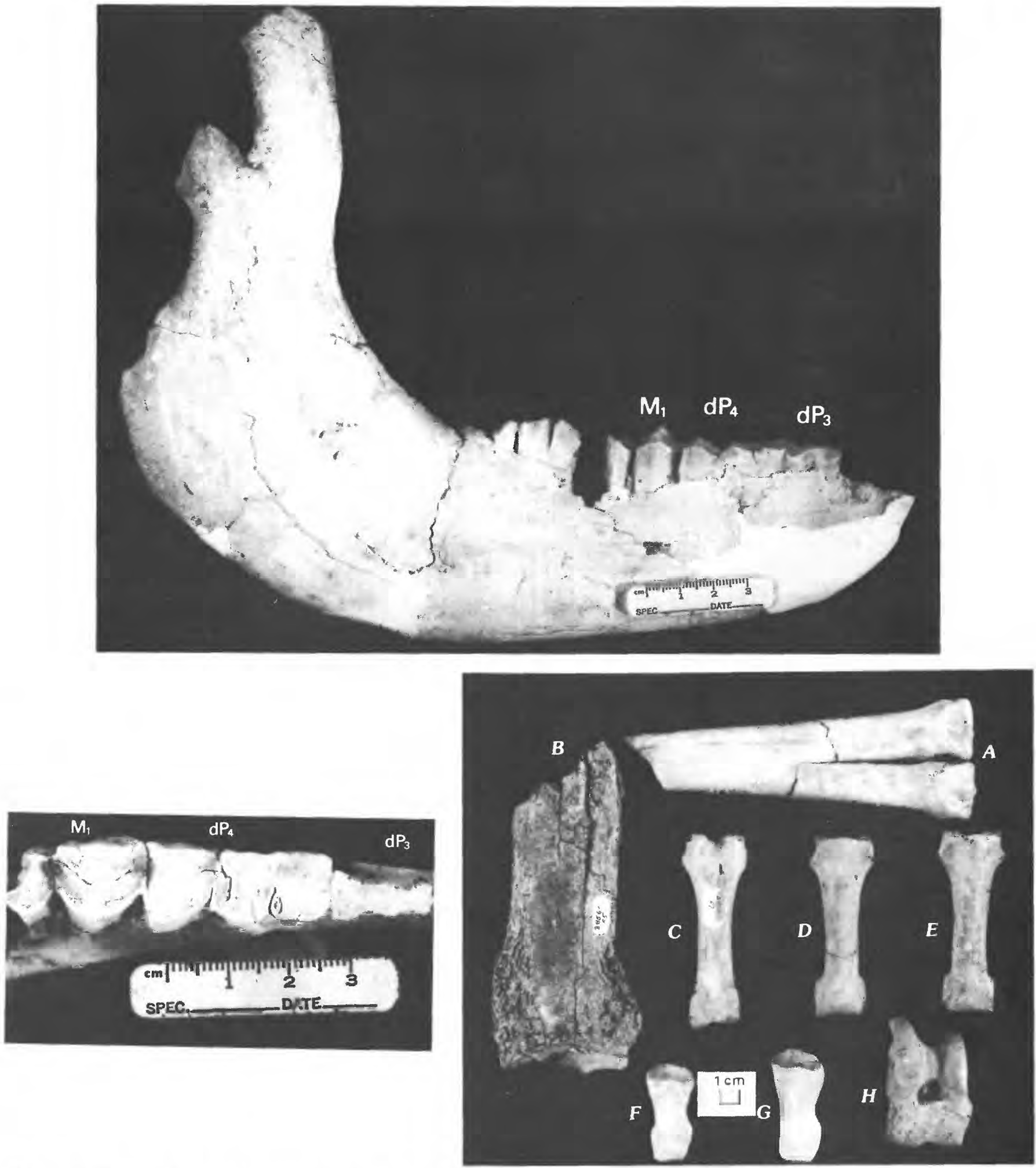

Figure 14.-Procamelus sp. or Aepycamelus sp., from localities D855 and 856, Citadel Plateau 15-minute quadrangle, Moffat County, Colo. Top, lateral view of right dentary; specimen D855-1; $\mathrm{M}$, molar; $\mathrm{dP}$, deciduous premolars. Lower left, occlusal view of right $\mathrm{dP}_{3-4}, \mathrm{M}_{1}$ (broken); D855-1. Lower right, $A$, anterior view of distal metapodial; D856-61. B, anterior view of right distal radius-ulna; D856-55. $C$, posterior view of proximal phalanx; D856-67. $D$, anterior view of proximal phalanx; D856-65. $E$, anterior view of proximal phalanx; D856-70. F, anterior view of medial phalanx; D856-74. $G$, anterior view of medial phalanx; D856-73. $H$, anterior view of right astragalus; D855-2. Scale is in centimeters. 
The dentary is long and deep, with a convex ventral edge. A mental foramen is present $18.7 \mathrm{~mm}$ below the dorsal edge of the dentary and $17 \mathrm{~mm}$ posterior to the canine. The dentary is thin near the angle. Above the angle the camelid hook is broken, and the condyle is heavily eroded and possibly laterally flattened. The coronoid process projects approximately $49 \mathrm{~mm}$ above its junction with the condyle. It has a slight medial inflection and is $25.5 \mathrm{~mm}$ wide anteroposteriorly.

Large size is the most distinctive feature of the postcranial elements of this camel. On the medial condyle of the humerus is a large tuberosity, more prominent than that found on the cf. Protolabis from this fauna. The common digital extensor depression (above the medial condyle) is shallower and shorter than that of cf. Protolabis.

The humeral articular surface of the radius is broad and has a small pit lateral to the median sagittal ridge. The lateral tuberosity is small. The shaft of the radius is broad-about $50 \mathrm{~mm}$ wide above the distal extremity. The ridge between the grooves for the carpal digital extensor is prominent.

The astragali are much larger than those of cf. Protolabis. Medially, the ridge between the navicular and medial malleolar facets is broad, contrasting with the narrow ridge on cf. Protolabis. Similarly, the tibial ligament surface is broader than that of cf. Protolabis.

A scaphoid, lunar, and cuneiform are referred to Procamelus sp. or Aepycamelus sp. on the basis of large size. The distal metapodials are distinguished from those of cf. Protolabis only by larger size. The medial phalanges are much larger and more robust than those of cf. Protolabis.

Comparisons and discussion.-The large camel from the Browns Park Formation was compared with camels in the Frick collection at the American Museum of Natural History. In size, the limb elements correspond well with those of undescribed specimens of Aepycamelus from the Pojoaque Member (late Barstovian and possibly early Clarendonian) of the Tesuque Formation, N. Mex., and with large specimens of Procamelus from the Burge Member (latest Barstovian) of the Valentine Formation of Lugn (1938), Nebraska. The dentition also closely resembles those of Procamelus and Aepycamelus. The crown height of the partially worn $M_{1}$ of specimen D855-1 is matched by specimens of the large Procamelus from the Burge Member. The $M_{1}$ of specimen D855-1 is higher crowned than in most Aepycamelus in the Frick collection; a few, however, from the Pojoaque Member of the Tesuque Formation, have teeth as high-crowned as specimen D855-1. The rami of these specimens of Aepycamelus are shallower than those of specimen D855-1. The ramal depth of specimen D855-1 matches that of adult specimens of Procamelus from the Burge Member. The size and morphology of the $\mathrm{dP}_{3-4}$ on specimen D855-1 was matched by specimens of Procamelus from the Clarendon fauna (Clarendonian); on these forms, however, the $M_{1}$ is higher crowned.

The postcranial material of the large Browns Park camel is about 12 percent smaller than that of Aepycamelus procerus (Matthew and Cook, 1909), which is a smaller species than $A$. giraffinus (Matthew, 1909). Specimen D856 cannot be compared with either A. priscus (Matthew, 1924), or A. leptocolon (Matthew, 1924), as they lack adequate description. Camel D856 limb materials are slightly smaller than those of $A$.(?) stocki (Henshaw, 1942), and Procamelus grandis Gregory, 1942.

Specimen D855-1 compares favorably with the lower jaws UCMP 32312 and UCMP 33420 from the Clarendonian Big Spring Canyon fauna (Gregory, 1942, figs. 32 and $33 \mathrm{~b})$. The individual represented by UCMP 32312 is younger than D855-1, and the jaw is thus slightly narrower dorsoventrally. The crown length of the $\mathrm{dP}_{4}$ is 25 percent longer than on specimen D855-1; the latter, however, is worn nearly to the roots. Data taken on mandibles of Protolabis coartatus show that the $\mathrm{dP}_{4}$ undergoes a 35-40 percent change in length from the crown to the base. Also, on UCMP 32312 there is a small labial intercolumnar tubercle between the second and third lobes, as on specimen D855-1. The length of the $\mathrm{dP}_{4}$ of UCMP 33420 is similar to that of specimen D855-1. The $M_{1}$ is not associated with these jaws. Gregory (1942) was unable to assign these specimens to either Procamelus or Pliauchenia. However, Loring and Wood (1969, p. 1209) assigned the relatively smaller UCMP 33446 from Big Spring Canyon to Pliauchenia because it possessed cement. They did not assign the larger deciduous jaws to any genus.

The camel from localities D855 and D856 cannot be positively excluded from Hesperocamelus. Comparison with the measurements given for $H$. alexandrae (Davidson, 1923), showed that the distal humeri and radii-ulnae are 10-20 percent larger on $H$. alexandrae. The proximal phalanges, though, are the same size on both camels. H. stylodon Macdonald, 1949 is smaller than $H$. alexandrae. The distal metapodials of D856 appear to be the same size as those of $H$. stylodon; other measurements cannot be made from Macdonald's illustrations. In most measurements, the large camel from D855 and D856 is slightly larger than Pliauchenia magnifontis Gregory, 1942. Megatylopus and Titanotylopus are much too large for the Browns Park camel. Alforjas taylori Harrison, 1979, is larger than the Browns Park camel, and evidently lacks a buccal 
tubercle on the $\mathrm{dP}_{4}$. Dentary D855-1 is excluded from Hemiauchenia because it lacks a so-called llama buttress on the $\mathrm{M}_{1}$; although a parastylid is present on specimen D855-1, the protostylid is absent. Dentary D855-1 is higher crowned than Paleolama. Other Miocene camels are smaller than the camel from localities D855 and D856.

The camel from localities D855 and D856 cannot, with certainty, be assigned to either Aepycamelus or Procamelus. Diagnostic differences in the lower deciduous teeth have never been established in the literature for Aepycamelus or Procamelus. Measurements on selected postcranial elements of Aepycamelus from the Pojoaque Member of the Tesuque Formation are given in table 13, along with measurements for the Browns Park camel.

\section{Subfamily CAMELINAE sp.}

Table 14, Figure 15

Referred material.-D856-75, left proximal fragment radius-ulna; D856-76, right distal fragment radius-ulna;

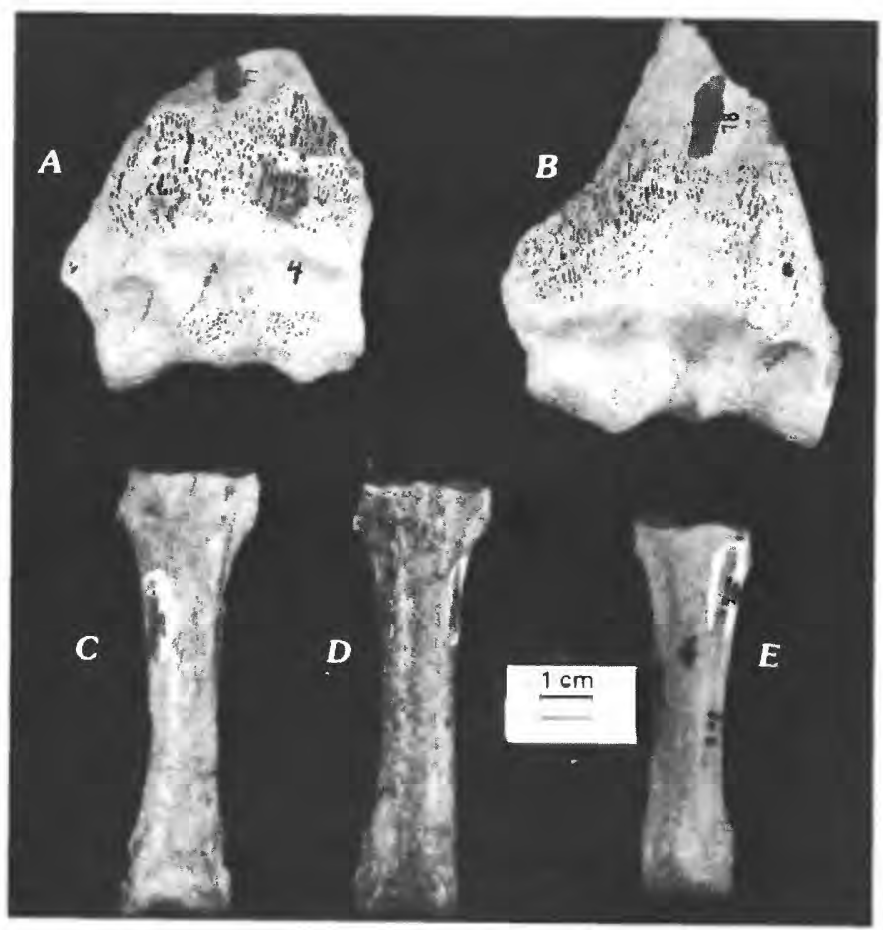

Figure 15.-Camelinae sp., from locality D856, Citadel Plateau 15-minute quadrangle, Moffat County, Colo. $A$, anterior view of right radius-ulna; specimen $\mathrm{D} 856-77$. $B$, anterior view of left distal radiusulna; D856-78. $C$, anterior view of proximal phalanx; D856-80. $D$, anterior view of proximal phalanx; D856-81. $E$, anterior view of proximal phalanx; D856-82.
TABLE 14.-Skeletal measurements of Camelinae sp. from locality D856, Citadel Plateau 15-minute quadrangle, Moffat County, Colorado

[Measurements in millimeters; leaders (-- $)$ indicate no data]

\begin{tabular}{|c|c|c|c|}
\hline Specimen & $\mathrm{n}$ & $0 . R$. & $x$ \\
\hline 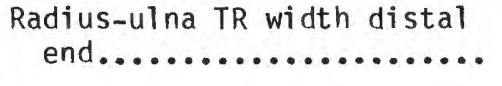 & 3 & $48.5-52.9$ & 51.4 \\
\hline Proximal phalanges (manus?): & & & \\
\hline $\begin{array}{l}\text { length.................. } \\
\text { TR proximal width....... } \\
\text { AP proximal length........ } \\
\text { TR distal width......... } \\
\text { AP distal length......... }\end{array}$ & $\begin{array}{l}4 \\
3 \\
4 \\
6 \\
6\end{array}$ & $\begin{array}{l}77 \cdot 0-83 \cdot 2 \\
21 \cdot 4-23 \cdot 0 \\
21 \cdot 2-22 \cdot 9 \\
18 \cdot 5-21 \cdot 5 \\
14 \cdot 8-19 \cdot 2\end{array}$ & $\begin{array}{l}79.6 \\
22.1 \\
21.9 \\
19.7 \\
16.5\end{array}$ \\
\hline $\begin{array}{l}\text { Proximal phalanx (pes?) } \\
\text { length.................... } \\
\text { TR proximal width........ } \\
\text { AP proximal length....... } \\
\text { TR distal width.......... } \\
\text { AP distal length......... }\end{array}$ & $\begin{array}{l}1 \\
1 \\
1 \\
1 \\
1\end{array}$ & $\begin{array}{l}66.7 \\
19.8 \\
17.6 \\
16.7 \\
13.6\end{array}$ & $\begin{array}{l}--- \\
--- \\
--- \\
---\end{array}$ \\
\hline
\end{tabular}

D856-77, right distal fragment radius-ulna; D856-78, left distal fragment radius-ulna; D856-79 through D856-83, proximal phalanges; D856-84, distal end of proximal phalanx; D856-85, distal end of proximal phalanx.

Description and comparisons.-A possible fourth camel is represented in this fauna. The distal humeri are indistinguishable from those of Procamelus or Aepycamelus sp. except by size. They are slightly smaller and are about the size of the distal humerus of Pliauchenia magnifontis.

Some proximal phalanges are indeterminate. The indeterminate phalanges are shorter and more slender than those belonging to Procamelus or Aepycamelus sp. These phalanges are larger than those referred to Michenia sp. and appear to be too large to belong to any species of Michenia. The phalanges are excluded from cf. Protolabis on the basis of morphology. The phalanges of Protolabis coartatus and the Protolabis from New Mexico, referred by Cope to Procamelus occidentalis (Cope, 1877, pl. 79, figs. 7 and $7 \mathrm{a}$ ), are shorter and have wider, rounder shafts than the D856 phalanges. The distal trochlea on these Protolabis specimens are also more massive and prominent than on D856. These indeterminate phalanges do not necessarily belong to the same camel as the indeterminate humeri, but are classified with them for the sake of convenience. 


\author{
Suborder RUMINANTIA Scopoli \\ Infraorder PECORA Linnaeus \\ Superfamily BOVOIDEA Gray \\ Family ANTILOCAPRIDAE Gray \\ Subfamily MERYCODONTINAE Matthew \\ Genus MERYCEROS Frick \\ Meryceros warreni (Leidy) \\ Table 15, Figure $16 A$
}

Cervus warreni Leidy, 1858, p. 23.

Cervus warreni Leidy. Leidy, 1869, pp. 172 and 379, pl. xxvii, fig. 12.

Meryceros warreni (Leidy). Frick, 1937, p. 361, figs. 2 (in part), 2a (in part), 25B (in part), 28 (in part), 28B, $28 \mathrm{C}, 35 \mathrm{~A}$ (in part), 39.

Holotype.-U.S.N.M. 149, right horn core.

Referred material.-D856-86, right horn core.

Distribution.-Niobrara River fauna (including Crookston Bridge Quarry) Nebraska; Trail Creek Quarry, Wyoming; Kennesaw fauna, Colorado, probable occurrence; Devil's Gulch Horse Quarry, Nebraska; Horse and Mastodon Quarry, Colorado: all late Barstovian land mammal age; possibly also from Lapara Creek fauna, Texas: Clarendonian.

Description.-The shaft of the horn core is short and transversely flattened and there is no apparent twisting. The two partial tines are parallel to the sagittal plane. Part of the orbit is preserved and has a small foramen on the medial wall. This foramen exits on the frontal bone and anteromesial to the base of the horn core.

Comparisons and discussion.-The short-shafted, transversely flattened horn core is assigned to Meryceros Frick, 1937. Meryceros is characterized by a single-forked, transversely flattened horn core.

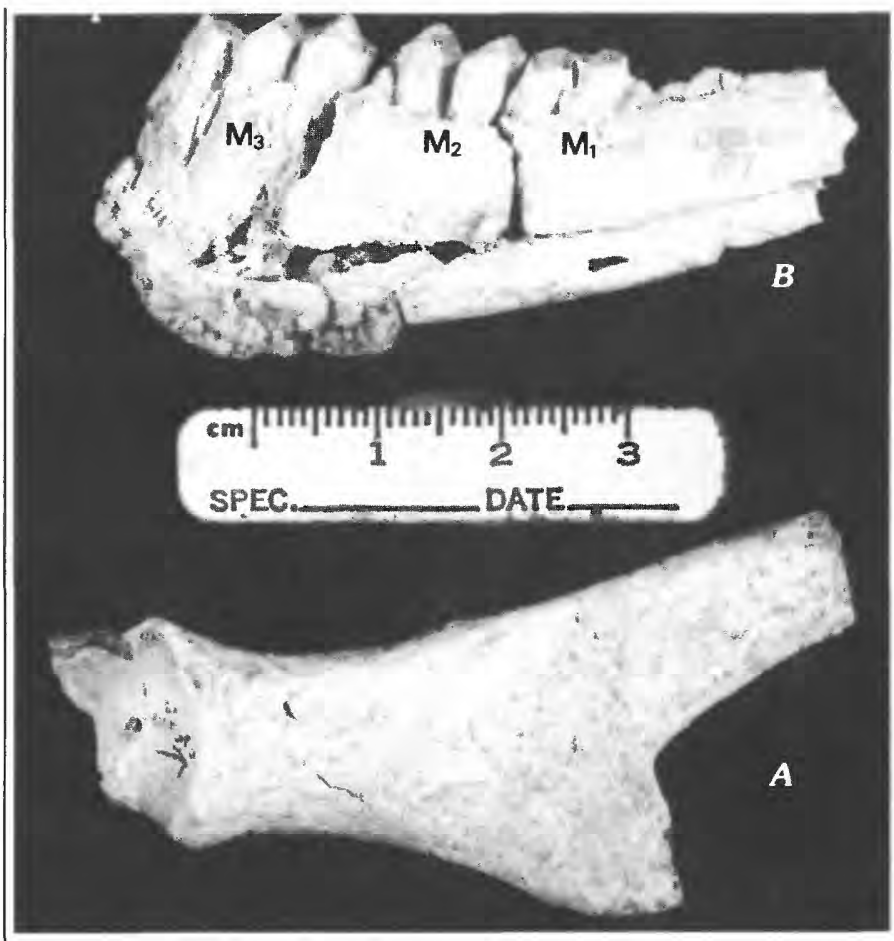

FIGURE 16.-Meryceros warreni and Merycodontinae sp., from locality D856, Citadel Plateau 15-minute quadrangle, Moffat County, Colo. A, Meryceros warreni, lateral view of right horn core; specimen D856-86. B, Merycodontinae sp., buccal view of right dentary with molars $\left(\mathrm{M}_{1-3}\right)$ of specimen D856-87.

TABLE 15.-Comparative measurements of Meryceros warreni from locality D856, Citadel Plateau 15-minute quadrangle, Moffat County, Colorado, and Meryceros crucensis from New Mexico

[Measurements in millimeters; leaders (---) indicate no data. F:AM-Frick, American Museum numbers; ESP-field designation, American Museum of Natural History]

\begin{tabular}{|c|c|c|c|c|c|c|}
\hline \multirow[b]{2}{*}{ Specimen } & \multicolumn{3}{|c|}{ M. warreni } & \multicolumn{3}{|c|}{ M. crucensis } \\
\hline & D856-86 & Type & $\begin{array}{l}F: A M \\
31319\end{array}$ & $\begin{array}{l}F: A M \\
51145\end{array}$ & $\begin{array}{l}\text { ESP } \\
400\end{array}$ & $\begin{array}{l}F: A M \\
51180\end{array}$ \\
\hline Height of fork above orbit. & . 37.0 & 40.3 & 34 & 38.7 & 32.3 & 53.0 \\
\hline Shaft TR above orbit....... & . 11.2 & ${ }_{14.6}$ & --- & 12.8 & 10.0 & 13.7 \\
\hline Shaft AP above orbit....... & $\cdot 14.5$ & 12.6 & 14 & 14.2 & 12.0 & 14.7 \\
\hline
\end{tabular}

$1_{\text {Burr present. }}$ 
Merycodus, which also has a short-shafted and singleforked horn core, is distinguished from Meryceros by a rounded shaft in cross-section.

The D856 horn core is referred to Meryceros warreni, as it closely resembles the type of that species (figured in Leidy, 1869, pl. 27, fig. 12). Although the shaft of the type is slightly less compressed transversely above the orbit and is taller than specimen D856-86, referred specimens in the American Museum overlap specimen D856-86 in shaft thickness just above the orbit. F:AM 31319 (Frick, 1937, fig. 39), in fact, is close to specimen D856-86. M. crucensis Frick, 1937, is a highly variable form with horn cores 20 percent shorter to 48 percent longer than that of $M$. warreni. Specimen D856-86 horn core cannot be separated from some allocated to $M$. crucensis and illustrated by Frick (1937, fig. 39). The range in size of the horn cores allocated to M. crucensis suggests that this species may include individuals of more than one species; the smaller individuals do not appear to be specifically distinct from $M$. warreni. $M$. joraki Frick, 1937, is also morphologically close to specimen D856-86, but has a wider shaft. M. crucianus Frick, 1937, has a smaller horn core than specimen D856-86. The horn cores of $M$. major Frick, 1937, $M$. nenzelensis Frick, 1937, and M. hookwayi (Furlong, 1935), are longer shafted than specimen D856-86.

\section{Meryceros sp.}

Table 16, Figures 17, 18A

Referred material.-D854-1, left $\mathrm{M}^{\mathrm{x}}$; D854-2, right $\mathrm{M}^{\mathrm{x}}$; D854-3, left dentary with $\mathrm{LI}_{2}\left(\right.$ ?), $\mathrm{LP}_{2-4}, \mathrm{LM}_{1-3}$; D854-4, right scapula; D854-5, right proximal fragment radius; D854-6, left proximal fragment tibia; D854-7, left distal fragment tibia; D854-8, left proximal fragment metatarsal and shaft; D854-9, left naviculocuboid; D854-10, left astragalus; D854-11, left calcaneum; D854-12 through D854-14, three proximal phalanges; D854-15, medial phalanx; all associated.

Description.-The upper molars are typically antilocaprid, being small and hypsodont. The mesostyle is prominent and narrow. The smaller parastyle and metastyle are subequal in size. The buccal wall of the paracone has a pronounced rib, but the buccal wall of the metacone is ribless.

The $\mathrm{LI}_{2}$ (?) is small and near vertical. The concave lingual side faces posteromesially. The premolars successively increase in size posteriorly. The $\mathrm{P}_{2}$ has the posterior part of the tooth much wider than the anterior part, whereas the $\mathrm{P}_{3}$ and $\mathrm{P}_{4}$ have the buccal and lingual walls more nearly parallel. The $\mathrm{P}_{3-4}$ have a mesially-inflected paraconid, separated by a U-shaped valley from a larger, mesially directed metaconid. This valley does not extend to the base of the enamel. A narrower valley separates the metaconid from the smaller, posterolingually directed entoconid. A small fossettid lies posteriorly on the entoconid and separates it from the entostylid on the back margin of the tooth. A small hypoconid forms the posterobuccal corner of the tooth, and is separated from the much larger protoconid by a broad and shallow basin. The protoconid lies opposite the valley between the paraconid and metaconid.

The lower molars closely resemble those of other antilocaprids. The lingual walls completely lack mesostylids. The metastylid is faintly suggested on the $M_{2}$, and the parastylid is rudimentary on the $M_{2}$ and $M_{3}$. A weak protostylid is present labially on the $M_{2}$ and $\mathrm{M}_{3}$, and extends nearly to the base of the enamel. The lingual walls of the metaconid and entoconid are convex. The third lobe of the $\mathrm{M}_{3}$ lacks a posterior stylid. The dentary is narrow dorsoventrally, especially anterior to the $P_{2}$. The ventral border beneath the cheek teeth is convex.

The postcrania from locality D854 were compared with those of some specimens of Antilocapra and Capromeryx, and with some illustrations of Paracosoryx and Ramoceras. Some differences are noted below.

The proximal radius (specimen D854-5) resembles that of the much larger Antilocapra. The bicipital rugosity, however, is less pronounced than in Antilocapra.

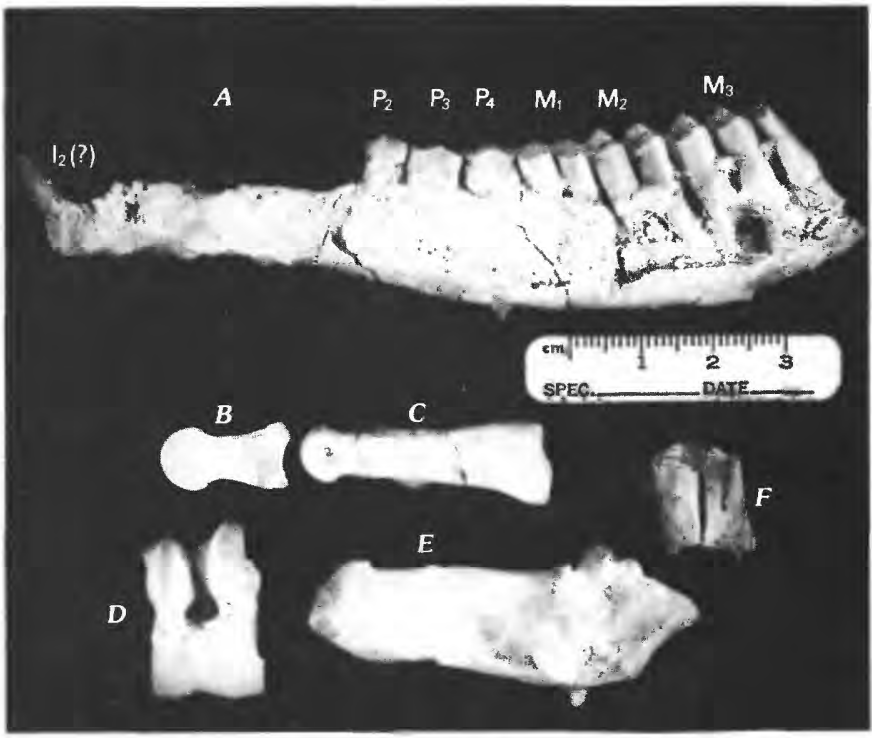

Figure 17.-Meryceros sp., from locality D854, Citadel Plateau 15-minute quadrangle, Moffat County, Colo. $A$, buccal view of left dentary with incisor $\left(\mathrm{I}_{2}\right.$ ?), premolars $\left(\mathrm{P}_{2-4}\right)$, and molars $\left(\mathrm{M}_{1-3}\right)$; specimen D854-3. $B$, side view of medial phalanx; D854-15. C, side view of proximal phalanx; D854-13. $D$, anterior view of left astragalus; D854-10. E, mesial view of left calcaneum; D854-11. $F$, lingual view of left $M^{\mathrm{x}}, \mathrm{D} 854-1$. 
TABLE 16.-Dental and skeletal measurements of Meryceros sp. from locality D854, Citadel Plateau 15-minute quadrangle, Moffat County, Colorado, and comparison with M. hookwayi from Nevada

[Measurements in millimeters; leaders (---) indicate no data. LACM-CIT, Los Angeles County Museum; collection formerly at the California Institute of Technologyl

\begin{tabular}{|c|c|c|}
\hline \multirow{2}{*}{$\frac{\text { Meryceros sp. }}{\text { D854-1 through D854-15 }}$} & \multicolumn{2}{|c|}{ M. hookwayi ${ }^{1}$} \\
\hline & $\begin{array}{c}\text { LACM-CIT } \\
712\end{array}$ & $\begin{array}{c}\text { LACM-CIT } \\
1257\end{array}$ \\
\hline$M^{x}$ APXTR........................ $12.3 \times 10.2$ & -- & -- \\
\hline$I_{2}$ APxTR....................... $4.1 \times 3.0$ & --- & -- \\
\hline$P_{2}$ APXTR.......................... $5.4 \times 3.0$ & --- & $6.0 x$ \\
\hline 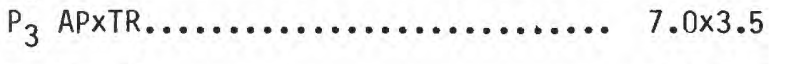 & --- & 6.9 \\
\hline$P_{4}$ APxTR...................... $8.5 \times 3.9$ & $7.8 x$ & $8.9 x$ \\
\hline$M_{1}$ APXTR........................ $8.5 \times 6.3$ & $9.2 x$ & -- \\
\hline$M_{2}$ APXTR....................... $9.6 \times 6.9$ & $10.4 x$ & $11.0 x$ \\
\hline 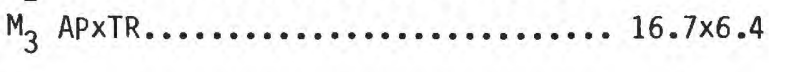 & $15.0 x$ & $14.0 x$ \\
\hline 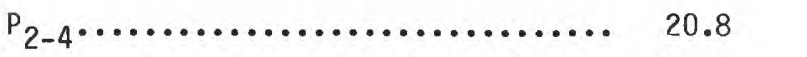 & --- & --- \\
\hline 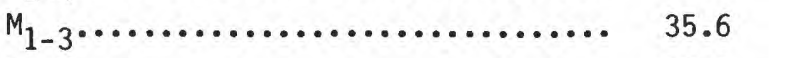 & --- & --- \\
\hline$P_{2}-M_{3} \ldots \ldots \ldots \ldots \ldots \ldots \ldots \ldots \ldots, \ldots$ & 59.6 & 56.8 \\
\hline Depth of jaw below $P_{2} \ldots \ldots \ldots \ldots \ldots$ & --- & --- \\
\hline Depth jaw below anterior lobe $M_{3} \ldots$ & --- & --- \\
\hline Proximal radius TR width............ & --- & --- \\
\hline Proximal tibia AP length........... 34.4 & --- & --- \\
\hline Distal tibia APXTR widths.......... $15.5 \times 20.3$ & --- & --- \\
\hline Proximal metatarsal APxTR widths.... $17.7 \times 17.3$ & --- & --- \\
\hline Naviculocuboid APXTR widths......... 19.3 19.2 & --- & --- \\
\hline 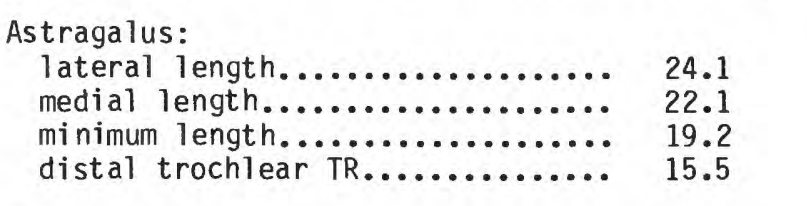 & $\begin{array}{l}--- \\
--- \\
---\end{array}$ & $\begin{array}{ll}--- \\
--- \\
---\end{array}$ \\
\hline 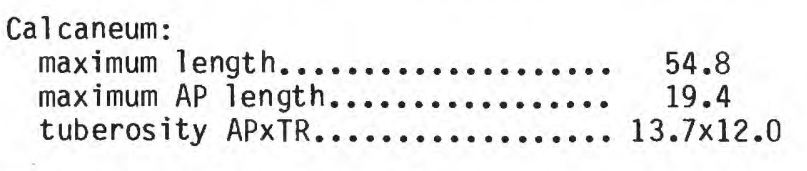 & $\begin{array}{l}--- \\
--- \\
---\end{array}$ & --- \\
\hline 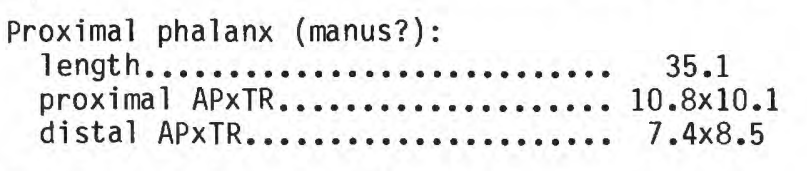 & --. & -- \\
\hline 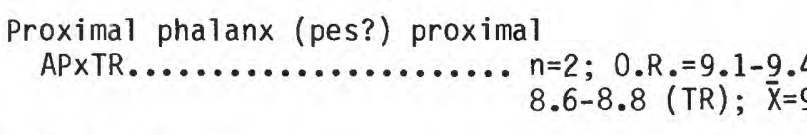 & & \\
\hline 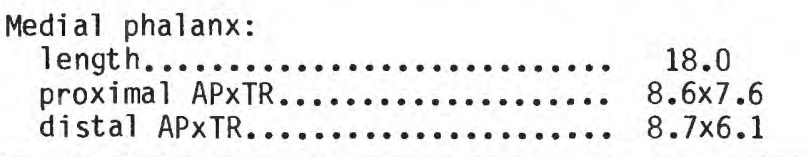 & $\begin{array}{ll}--- \\
---\end{array}$ & $\begin{array}{ll}--- \\
--- \\
--\end{array}$ \\
\hline
\end{tabular}

1Measurements taken from Furlong (1935, table 1). 


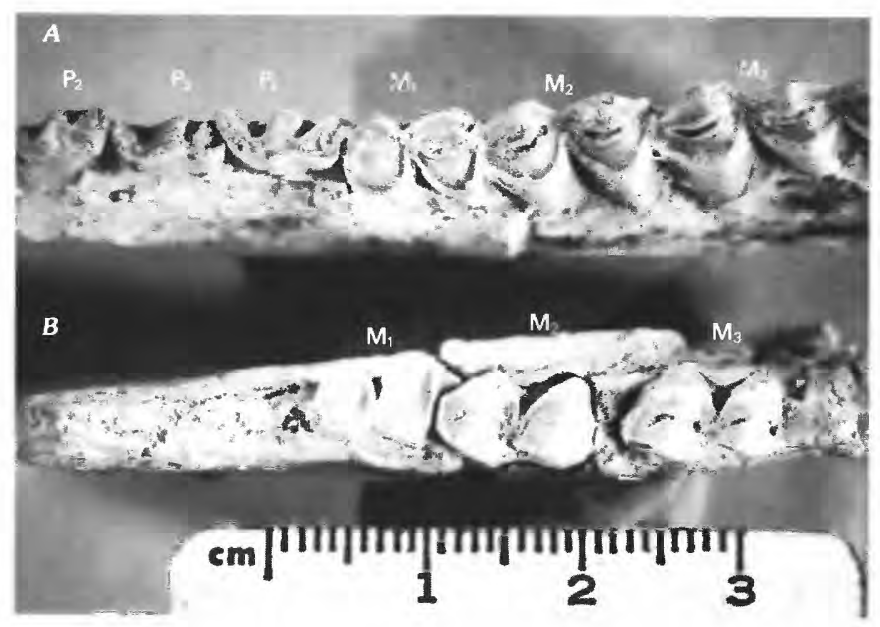

Figure 18.-Meryceros sp. and Merycodontinae sp., from localities D854 and D856, Citadel Plateau 15-minute quadrangle, Moffat County, Colo. A, Meryceros sp., occlusal view of left dentary, showing premolars and molars $\left(\mathrm{P}_{2}-\mathrm{M}_{3}\right)$; specimen D854-3. $B$, Merycodontinae sp., occlusal view of right dentary, showing $\mathrm{M}_{1-3}$; specimen D856-87.

Proximally, the tibia (specimen D854-6) has the medial condyle and the tubercles of the spine preserved. Medial to the popliteal notch, the attachment tubercle for the posterior cruciate ligament is less pronounced on specimen D854-6 than in Antilocapra. Distally, the groove for the flexor digitalis longus is deeper and more sharply defined, and the anteromedial distal process between the astragalar articular grooves is narrower in specimen D854-7 than in Antilocapra. Laterally, the fibular articular facets are more strongly developed on Antilocapra. The anterior fibular facet on specimen D854-7 is saddle-shaped, being concave from side to side and convex fore-aft. In Antilocapra it is strongly convex, forming a rollerlike surface. The posterior fibular facet is shallower and the fibular groove is shallow and less troughlike than in Antilocapra.

On the proximal fragment of the metatarsal (specimen D854-9), the ectomesocuneiform facet is less posteromesially expanded than in Antilocapra. The entocuneiform facet is more triangular owing to greater posterior extension in Antilocapra; it is rounder owing to less posterior extension in Capromeryx. The posterior groove bounding the cuboidal facet is less deep in specimen D854-9 than it is in Antilocapra.

On the naviculocuboid (specimen D854-10), the metatarsal 4 facet lies more distally from the entocuneiform facet than in Antilocapra. The latter facet on specimen D854-10 is relatively longer than on Paracosory $x$ and Capromeryx and resembles that of $A n$ tilocapra. The proximoposterior tuberosity on the medial side of the naviculocuboid is smaller and less rugose than in Antilocapra. The medial calcanear facet resembles that of Antilocapra and Capromeryx in that it is more strongly developed than in Paracosoryx.

The anterodorsal tuberosity of the calcaneum (specimen D854-11) resembles that of Paracosoryx and Capromeryx in that it is less strongly developed than in Antilocapra. The sustentacular process is slightly less prominent than in Antilocapra. The astragalar facet anterior to the cuboidal facet is much smaller on specimen D854-11 than on Antilocapra.

The proximal phalanx is more slender on the locality D854 fossil antilocaprid than it is on Antilocapra and Ramoceros. The proximolateral articular surface is smaller and more distally displaced in relation to the proximomedial articular surface than in Antilocapra. The plantar tuberosities are less prominent than in $\mathrm{An}$ tilocapra. The medial phalanx is more slender and smaller than in Antilocapra.

Comparisons and discussion.-Because the horn core is lacking, dental criteria must be used to establish generic identification. Henshaw noted that merycodont evolutionary trends include size increase of the $M_{3}$, lengthening of the post-symphyseal diastema (1942, p. 161) and reduction in the size of the premolars (Henshaw, 1940, p. 26). These characteristics can be determined from most illustrations of antilocaprid dentitions. In their analysis of Merycodus necatus and Cosoryx furcatus, Skinner and Taylor (1967, p. 44) mentioned reduction of premolars and crown height of molars as diagnostic.

The antilocaprid from locality D854 is distinguished from all genera in the subfamily Antilocaprinae by possessing less hypsodont molars. The absence of a posterior fourth lobe on the $\mathrm{M}_{3}$ supports placement of the locality D854 antilocaprid within the Merycodontinae, although the presence of the $M_{3}$ fourth lobe is somewhat variable in the Antilocaprinae (Skinner, 1942; Webb, 1973).

The dentition of Ramoceros osborni (Matthew, 1904) is about 12 percent shorter than that of specimen D854-3, based on F:AM 31636 (Frick, 1937, fig. 43). The premolars are slightly shorter and the molars less anteroposteriorly expanded than in specimen D854-3.

Based on F:AM 31019 and F:AM 31020 (Frick, 1937, fig. 35a), specimen D854-3 differs from Merriamoceros in having a dentition 15 percent longer. The premolar row is 10 percent shorter, the $P_{3}$ paraconid is less lingually inflected, and the $M_{3}$ is less expanded in Merriamoceros.

The premolars of both Cosoryx furcatus Leidy, 1869, and Cosoryx cerroensis Frick, 1937, are highly reduced in relation to those of specimen D854-3, and the $M_{3}$ is higher crowned (AMNH 9825, Frick, 1937, fig. 45).

Merycodus sabulonis Matthew and Cook, 1909, is distinguished from specimen D854-3 by having more reduced premolars, and the base of the $M_{3}$ is less 
anteroposteriorly expanded than in specimen D854-3.

The premolars of Cosoryx (Paracosoryx) alticornis Frick, 1937, (Frick, 1937, fig. 47), are about 20 percent shorter, the molars are slightly shorter, and the $\mathrm{M}_{3}$ is more anteroposteriorly expanded at the base than in specimen D854-3. The premolars of $C$. (P.) furlongi Frick, 1937, (illustrated in Furlong, 1927, pl. 26, fig. 1) are about 10 percent shorter than on specimen D854-3. The dentition of $C$. $(P$.$) loxoceros (Furlong, 1935) is$ about 20 percent shorter than that of specimen D854-3. $C$. (P.) wilsoni Frick, 1937, has premolars only slightly more reduced than those of specimen D854-3, and the length of the $M_{3}$ is nearly the same. However, the jaw length anterior to the $\mathrm{P}_{3}$ is much less in $C$. (P.) wilsoni, resulting in an abbreviated look.

The premolars of Meryceros crucensis Frick, 1937, are reduced compared with those of specimen D854-3, and the $\mathrm{P}_{4}$ possesses a posterobuccal sulcus. $M$. nenzelensis Frick, 1937, is similar to specimen D854-3 in having nonreduced premolars. However, the base of the $\mathrm{M}_{3}$ is longer in $P$. nenzelensis and there is a posterior stylid present on the third lobe of the $M_{3}$ (Frick, 1937, fig. 44, F:AM 31902). The premolars are more reduced and the cheek tooth row is shorter in Meryceros warreni (Leidy, 1858). The $\mathrm{P}_{2}-\mathrm{M}_{3}$ length of specimen D854-3 is greater than in $M$. joraki Frick, 1937. However, in Frick's many illustrations (1937, figs. 46 and 47) of this species, some have unreduced premolars and short $M_{3}$, and others have reduced premolars and long $M_{3}$. These latter specimens also possess posterior stylids on the $\mathrm{M}_{3^{\prime}}$. The length of the cheek tooth row of specimen D854-3 is very close to that of $M$. hookwayi (Furlong, 1935). The premolars of $M$. hookwayi are relatively unreduced and the $M_{3}$ length is only slightly less than in specimen D854-3; this is due to its being less worn. The posterobuccal sulcus of the premolars is deeper on $M$. hookwayi than on specimen D854-3. The $\mathrm{P}_{4}$ of $M$. hookwayi differs from that of specimen D854-3 in possessing a small fossettid posterior to the anterolingual sulcus; this fossettid is formed by a lingual enamel connection between the metaconid and paraconid, resulting in a $\mathrm{P}_{4}$ morphologically similar to that of Antilocapra. The anterior buccal and lingual stylids of the $\mathrm{M}_{2}$ and $\mathrm{M}_{3}$ appear to be slightly stronger on $M$. hookwayi. $M$. hookwayi is similar to specimen D854-3 in that it lacks a stylid on the $M_{3}$ posterior lobe. $M$. crucianus Frick, 1937, has a dentition much smaller than that of specimen D854-3. Meryceros sp., reported by Cassiliano (1980, p. 48), has shorter premolars relative to the molars than in specimen D854-3.

On the basis of tooth size, nonreduction of premolars relative to molars, and $M_{3}$ crown height, specimen D854-3 most closely resembles species of Meryceros.
The molariform $\mathrm{P}_{4}$ with small fossettid on $M$. hookwayi is a derived characteristic, which nonetheless is merycodontine in development. According to Frick $(1937$, p. $22-23)$, "the worn to slightly worn $P_{4}$ of***merycodonts differs from that of Texoceros and Ilingoceros in the tendency to development of the metaconid rather than the metastylid portion of the median accessory column. In the $\mathrm{P}_{4}$ of the Recent pronghorn, both metaconid and metastylid are developed, enclosing anterior and posterior fossettes." The $\mathrm{P}_{4}$ fossettid on $M$. hookwayi is anteriorly placed, forming from the union of the paraconid and the anterior (metaconid) portion of the median accessory column. If $M$. hookwayi is correctly referred to Meryceros (the type of $M$. hookwayi is a ramus; the horn cores from the same locality were referred to that species on the basis of size), then the genus Meryceros contains forms both with and without a $\mathrm{P}_{4}$ fossettid. Likewise, the presence of the $M_{3}$ posterior stylid, a derived characteristic, is variable in Meryceros. The individual morphological characteristics of the teeth of antilocaprids are here considered less important taxonomically than are the size and relative proportions of the teeth. Upon this basis, specimen D854-3 falls within the range of variation of Meryceros, as this genus was constituted by Frick (1937).

\section{Merycodontinae sp. \\ Figures $16 B, 18 B$}

Referred material.-D856-87, right ramus with $\mathrm{M}_{1-3}$. Description. - There is little that is distinctive about these teeth. The $M_{3}$ possesses a minute posterior stylid. Dental measurements (in $\mathrm{mm}$ ) for this fossil are as follows: $\mathrm{M}_{1} \mathrm{AP} \times \mathrm{TR}, 7.8 \times 5.6 ; \mathrm{M}_{2} \mathrm{AP} \times \mathrm{TR}, 8.8 \times 6.3$; $\mathrm{M}_{3} \mathrm{AP} \times \mathrm{TR}, 13.6 \times 6.0 ; \mathrm{M}_{1-3} \mathrm{AP}, 36.4$.

Comparisons and discussion.-Measurements were taken on $M$. warreni F:AM 31276 from the Devil's Gulch Member of Skinner and others (1968) of the Valentine Formation (late Barstovian) of Lugn (1938), and on $M$. warreni johnsoni N.S.M. 1.23.7.34 and N.S.M. 2.3.8.34 (these last two illustrated in Frick, 1937, fig. $28 \mathrm{~b})$. The $\mathrm{M}_{1-3}$ is 10-12 percent shorter on these specimens than on specimen D856-87. Frick, unfortunately, did not give measurements or illustrations of the dentitions of $M$. crucensis. In size, specimen D856-87 falls close to the largest specimens of $M$. joraki illustrated by Frick (1937, fig. 47). $M$. joraki includes specimens with the $M_{1-3}$ length from 3 to 26 percent shorter than on specimen D856-87; this large range suggests that more than one species could be included in $M$. joraki. The largest specimen of $M$. joraki differs from D856 in that it has a posterior stylid on the $\mathrm{M}_{3}$ third lobe. $M$. nenzelensis F:AM 31902, illustrated by Frick 
(1937, fig. 44), is slightly larger than specimen D856-87 and has a posterior stylid on the $\mathrm{M}_{3}$. The dentition of M. crucianus is too small for that of specimen D856-87. The $\mathrm{M}_{1-3}$ length is close to that given for $M$. hookwayi (Furlong, 1935, table 1), and specimen D856-87 resembles $M$. hookwayi in that it lacks a posterior stylid on the $\mathrm{M}_{3}$. Specimen D856-87 differs from Meryceros sp. D854-3 in that the basal part of the $\mathrm{M}_{3}$ is less anteroposteriorly expanded. This difference, however, is no greater than that seen on specimens of Cosoryx furcatus (Frick, 1937, fig. 45, especially F:AM 31274 and AMNH 9825).

Unfortunately, specimen D856-87 cannot be excluded from Cosoryx, especially the two specimens just noted. Although Meryceros and Cosoryx are distinguished from each other by the relative reduction of the premolars, they cannot be so distinguished by their molars alone. The crown height of specimen D856-87 also overlaps with that of $C$. furcatus (Frick, 1937, fig. 45, F:AM 31724). Specimens of Cosoryx (Paracosoryx) alticornis (Frick, 1937, fig. 47, F:AM 31041 and 31043) also cannot be distinguished from specimen D856-87. The molars of F:AM 30944, a specimen which Frick (1937, fig. 41) could not allocate to Ramoceros, Cosoryx, or Meryceros, are virtually indistinguishable from those of specimen D856-87.

This lower dentition may belong to the same animal as the horn core, that is, to Meryceros warreni. The 10 percent difference in the $\mathrm{M}_{1-3}$ length with that of $M$. warreni may be within the range of variation of that species, especially if the 23 percent range of variation seen in $M$. joraki is truly due to individuals of just that one species. However, considering the diversity of merycodonts in the Barstovian and Clarendonian, there are no compelling reasons why more than one species cannot be found in the same quarry. For the present, the best procedure is to recognize this specimen as generically indeterminate.

\section{MAMMALIAN AGE AND CORRELATION}

Locality D857 has yielded fossils indicative of the Hemingfordian land mammal age. The horse from this locality most closely resembles Parahippus leonensis from the Thomas Farm and other Hemingfordian localities of Florida. The presence of cement on the teeth helps establish a maximum age for the rocks of this locality. In Nebraska, the type specimen of Parahippus nebrascensis, a form without cement, was collected from the upper Arikareean Marsland Formation of Schultz (1938). Galusha $(1975$, p. 66) noted that some Parahippus teeth from the superjacent Runningwater Formation of Cook (1965) "have a light coating of cement; most do not." The Runningwater Formation is considered early Hemingfordian (Tedford, 1981, p. 1015). Galusha $(1975$, p. 58) noted that a skeleton of Parahippus cf. P. vellicans was found in the Box Butte Formation of Galusha (1975), which overlies the Runningwater Formation, and is late Hemingfordian in age (Skinner and others, 1977, fig. 10). He stated that this specimen has "a fairly strong covering of cement on both the premolars and molars," which is thicker than that on horse teeth from the Thomas Farm fauna of Florida or the Garvin Gulley fauna of Texas. Thus, the presence of cement suggests that the D857 horse is at least postMarsland in age.

Patton (1969, p. 210) judged that the Thomas Farm fauna is slightly younger than the Garvin Gulley fauna, which he tentatively correlated with the Runningwater fauna. The stage of evolution of the equids suggests that the Thomas Farm is no younger than the Box Butte fauna and may be slightly older; there are no Merychippus recognized from the Thomas Farm, while the earliest Merychippus in Nebraska occurs in the Box Butte Formation, and the Box Butte Parahippus has slightly more cement on the teeth than the Thomas Farm Parahippus (Galusha, 1975, p. 59). Tedford and Hunter (1984) noted a near-species identity of horses in the Thomas Farm and correlative Florida faunas with horses from the youngest part of the Runningwater Formation.

Thus, the presence of $P$. leonensis suggests an early to late Hemingfordian age for locality D857. However, as indicated previously, the Browns Park horse is not all that different from Parahippus avus. In the Great Plains and Great Basin, Parahippus persisted into the early Barstovian. The type specimens of Parahippus avus and $P$. brevidens are part of the Mascall fauna of Oregon, and the type specimen of $P$. coloradensis is probably from the Eubanks local fauna of northeastern Colorado. Other early Barstovian occurrences of Parahippus include the Virgin Valley, High Rock Canyon, and Camp Creek faunas of Nevada, the Sucker Creek, Skull Spring, and Beatty Buttes faunas of Oregon, and the North Coalinga fauna of California. Thus, the minimum age for the fauna from locality D857 is early Barstovian, based only on the occurrence of Parahippus.

The age of the fauna from locality D857 can possibly be further refined by the presence of Blickomylus galushai. This species is found in both the Chamisa Mesa Member of Galusha (1966) and the Cañada Pilares Member of Gawne (1981b) of the Zia Sand. The occurrences of $B$. galushai in the Chamisa Mesa and Cañada Pilares Members are considered early Hemingfordian by Gawne (1981a, p. 1007), and early to early late Hemingfordian by Tedford (1981, fig. 3). Frick and Taylor 
(1968, fig. 14) show Blickomylus as Hemingfordian in age. B. galushai also occurs in the Split Rock local fauna (Munthe, 1979). Munthe considered the Split Rock local fauna to be most similar to the fauna from the late Hemingfordian Box Butte Formation of Galusha (1975), though also showing strong similarities to the late Hemingfordian fauna from the Sheep Creek Formation.

The evidence as outlined above indicates that the fauna from locality D857 is early to late Hemingfordian in age. Although the presence of Parahippus might also suggest an early Barstovian age, because Blickomylus has not yet been found in Barstovian faunas, we restrict the age of locality D857 to the Hemingfordian.

The fossils from the other localities in the Browns Park Formation indicate an age younger than Hemingfordian. The canid, Tomarctus temerarius, has been reported only from late Barstovian faunas, and is part of the Niobrara River fauna (Webb, 1969) which was collected from the Crookston Bridge Member of the Valentine Formation (Skinner and others, 1968, p. 404). Tomarctus paula is from the late Barstovian Tonopah fauna of Nevada. Early Barstovian assemblages commonly include the large form, Tomarctus rurestris. Reported Clarendonian occurrences of Tomarctus include large species, such as $T$. euthos or $T$. robustus. An exception to this is the canid, of indeterminate genus and species, reported by Wilson (1960) from the Lapara Creek fauna of Texas. As noted, this canid is similar to specimen D856-1.

The stage of evolution of the Browns Park Megahippus can be matched with forms of Barstovian age. Specimen D856-9 is similar in size to Hypohippus affinis. As noted, M. mckennai, from near the base of the upper member of the Barstow Formation (Tedford and Alf, 1962, p. 114), is also near the size of $H$. affinis. The lingual cingulum on the $M_{1}$ of specimen D856-9 is less well developed than on Megahippus cf. M. matthewi from the Clarendonian Cedar Mountain fauna from Nevada, and less well developed than on the type specimen of $M$. matthewi from the latest Barstovian Burge fauna of Nebraska. The $\mathrm{dP}_{1}$ on D856-9 is larger than on latest Barstovian and early Clarendonian Megahippus. As noted, the Browns Park specimen was matched with one in the Frick collection from the Pojoaque Member of the Tesuque Formation.

The limb bones of $\mathrm{cf}$. Protolabis are not useful for correlation because the genus Protolabis extends from the Hemingfordian through the Clarendonian. The genus Michenia extends from the late Arikareean to the Clarendonian; the relative reduction and simplification of the $\mathbf{P}_{2}$ and $\mathbf{P}_{3}$, and the suppression of the $\mathbf{P}_{1}$, suggest a post-Marsland (post-Arikareean) stage of evolution for the Michenia from the Browns Park. The early-middle Clarendonian Michenia yavapaiensis from
Milk Creek, Ariz., has a $P_{2}$ that is variably present, suppressed, or lost; when present it averages about $5 \mathrm{~mm}$ in length, which is close to that of the Michenia, D856-13.

The large Procamelus sp. or Aepycamelus sp. of the Browns Park Formation seems to represent a late Barstovian stage of evolution. The size of the limb bones and the crown height of the $M_{1}$ match a few American Museum specimens from the Pojoaque Member of the Tesuque Formation, that is, specimens of late Barstovian and possibly early Clarendonian age (Tedford, 1981, fig. 2; Barghoorn, 1981, p. 1040). The large Browns Park camel is also matched in these characteristics by Procamelus from the latest Barstovian Burge fauna. Clarendonian Procamelus from the Clarendon fauna of Texas have higher crowned $M_{1}$ 's than those from the Burge fauna; hence, the Browns Park camel probably represents a pre-Clarendonian stage of evolution.

Meryceros warreni is apparently limited to late Barstovian faunas. The type specimen is from the composite fauna from the valley of the Niobrara River (see Webb, 1969, for discussion), and may have been from the lower part of the Valentine Formation, in which the M. warreni-type horn is characteristic (Skinner and Taylor, 1967, p. 45). The type of $M$. warreni johnsoni is from the Crookston Bridge Member of the Valentine Formation (Skinner and Johnson, 1984). Galbreath $(1953$, p. 35$)$ reported its probable occurrence in the late Barstovian Kennesaw fauna of northeastern Colorado, apparently basing this judgment on Frick's (1937, p. 367) reported occurrences in the Horse and Mastodon Quarries in the Pawnee Creek Formation of Galbreath (1953). In an unpublished correlation chart, R. H. Tedford (written commun., 1975) showed the Horse and Mastodon Quarries to be slightly older than the Kennesaw fauna, but younger than the early Barstovian Eubanks fauna. Forsten $(1970$, p. 50$)$ reported the presence of Meryceros warreni-type horns from the Trail Creek fauna of Wyoming (but refers them to Merycodus cf. necatus, as she considers $M$. warreni a synonym of $M$. necatus). The Trail Creek fauna, considered Barstovian by Voorhies (1965) and Forsten (1970), was assigned a Valentinian ${ }^{4}$ age by Cassiliano (1980, p. 64), who noted it contained genera and species also found in each of the three members of the Valentine

\footnotetext{
${ }^{4}$ Valentinian is an informal land mammal age used by some paleontologists and stratigraphers, and is based on faunas from the Valentine Formation of Nebraska. Previously it had been used as roughly equivalent to a combined late Barstovian (in part) and early Clarendonian time. However, with the placement of the Burge fauna in the latest Barstovian, the Valentinian falls entirely within the late Barstovian. For discussions of the term Valentinian, see Skinner and others (1968); Webb (1969); Cassiliano (1980); and Skinner and Johnson (1984).
} 
Formation. Mercyceros warreni is present in American Museum collections from the late Barstovian Devil's Gulch Horse Quarry of Nebraska.

Meryceros crucensis is from the late Barstovian and possibly early Clarendonian Pojoaque Member of the Tesuque Formation. $M$. joraki, the other short-shafted Meryceros, is from the upper member of the Barstow Formation (Frick's "First Division" (1937, p. 367)). A longer-shafted form, Meryceros cf. M. major, has been reported from the Clarendonian Ogallala-Wolf Creek fauna of South Dakota, and Merriam (1916, fig. 42) illustrated a probable long-shafted Meryceros from the Clarendonian Cedar Mountain fauna of Nevada. Some of Voorhies' (1969) material from the Verdigre fauna may be Meryceros. No Meryceros has been reported from early Barstovian faunas. Short-shafted Meryceros does not seem to have persisted later than the earliest Clarendonian, and is most common in late Barstovian faunas.

The Meryceros from locality D854 is probably the same age as the fossils from localities D855 and D856. As noted in the discussion of specimen D854-3, the reduction of the premolars relative to the molars, and the total length of the cheek tooth row, is similar to that of $M$. hookwayi from the late Barstovian Tonopah fauna. Slight morphological differences in the teeth prevent the Browns Park specimen from being assigned to $M$. hookwayi.

The faunal evidence indicates most strongly a late Barstovian (post-Lower Snake Creek to Burge) age for the fossils from localities D854, D855, and D856 (Cedar Springs Draw local fauna), although an early Clarendonian age is not entirely excluded. The primitive Megahippus may indicate a pre-latest Barstovian (preBurge) age for the fauna. The Cedar Springs Draw local fauna shares Meryceros warreni with the Niobrara River fauna (that is, the fauna from the Crookston Bridge Member of the Valentine Formation (latest Barstovian)). In addition, these two faunas share Protolabis, and the two large camels, Aepycamelus and Procamelus, are both present in the Niobrara River fauna. The D856 locality shares Meryceros warreni with the Trail Creek fauna (Valentinian); in addition, Forsten $(1970$, p. 49) gave measurements for a deciduous Aepycamelus sp. (called (?)Alticamelus sp. by Forsten, and corrected to Aepycamelus by Cassiliano, 1980) which are similar to those for the large Browns Park camel. Tomarctus cf. T. paula is close to Tomarctus paula from Tonopah (late Barstovian). Tonopah also has Aepycamelus(?) stocki. Meryceros, however, is represented at Tonopah by the longer shafted $M$. hookwayi. Except for the occurrences in the Browns Park Formation, $M$. warreni has been reported only east of the Rocky Mountains. The quarries D854, D855 and D856 have a high generic similarity to the Barstow fauna, but none of the species are demonstrably the same. The strongest similarity, however, may be to the fauna from the Pojoaque Member (late Barstovian to possibly early Clarendonian) of the Tesuque Formation, which shares Megahippus and possibly Aepycamelus sp. Meryceros crucensis occurs in the Pojoaque Member of the Tesuque Formation; as defined by Frick (1937), $M$. crucensis includes forms with horn cores nearly identical to those of $M$. warreni. Both Protolabis and Michenia occur in the Pojoaque Member of the Tesuque Formation.

There is little similarity between the Browns Park fossils described in this study and those described by Peterson (1924, 1928). Peterson's 1928 Browns Park fauna consisted of the following forms:

Bassariscops willistoni

Ticholeptus?

Camelidae gen. et sp. indet.

Camelidae near Stenomylus

Merycodus? sp.?

Aphelops ceratorhinus

Chalicotheroidea

Serridentinus fricki

These fossils were found at several localities throughout the formation, and at least one was collected from another formation. The camelid near Stenomylus is considered an indeterminate antilocaprine by Frick and Taylor (1968, p. 7, footnote). Skinner (1968, p. 17) pointed out that the presumed chalicothere is actually a Teleodus from the Duchesne River Formation near Vernal, Utah. McGrew (1951, p. 56) considered the supposed Ticholeptus to be an indeterminate oreodont. The other camelid and Merycodus? sp. consist of unillustrated postcrania. The Bassariscops was found "one mile south and west of Sunbeam, Moffat County, Colorado" (Peterson, 1924, p. 300), whereas the Aphelops and Gomphotherium (= "Serridentinus" = "Trilophodon") were found about 22 miles farther west at Douglas Mountain, near Greystone, Colo.

Peterson (1928, p. 88) judged the Browns Park assemblage to be similar in age to faunas from "the Pawnee Creek of Colorado, the Madison Valley, probably the Flint Creek and Deep River of Montana; the Santa Fe of New Mexico; the Mascall of Oregon, and the Virgin Valley of Nevada." McGrew (1951, p. 56) considered the Browns Park Formation to be middle Miocene (Hemingfordian). However, this age was based partly on the presence of the supposed chalicothere. J. LeRoy Kay (oral commun. related in Untermann and Untermann, 1954, p. 186) considered Bassariscops and Aphelops to indicate a late Miocene (Barstovian) age.

The only record of Bassariscops willistoni is from the Browns Park Formation. Frailey (1979, p. 134-140) has 
described a second species of Bassariscops, B. achoros, from the Arikareean Buda local fauna of Florida. The temporal relationship of the two species relative to each other are unknown, but the Florida occurrence suggests that the Browns Park Bassariscops may be as old as Arikareean.

The type and referred material of Aphelops ceratorhinus are from the Lower Madison Valley, Montana (Douglass, 1903; 1908). Matthew (1932) considered Aphelops montanus Douglass, 1903, from the Flint Creek local fauna, Montana, synonymous with $A$. ceratorhinus. According to Black (1961, p. 75), the Flint Creek local fauna is probably middle to late Barstovian and probably equivalent to part of the Lower Madison Valley fauna.

Osborn (1936, p. 312) considered "Trilophodon" fricki to be one of the most primitive gomphotheres in North America, and assigned a middle to late Miocene age to Peterson's fauna. Tobien $(1973$, p. 223) synonymized Gomphotherium fricki with Gomphotherium productum from the Pojoaque Member of the Tesuque Formation, and $(1973$, p. 218) considered the Browns Park specimen to be one of the earliest representatives of North American mastodonts. Gomphotheres do not occur in North America until the late Barstovian, when they appear as an immigrant group (Tedford, 1981, p. 1012).

Given that Gomphotherium productum is an early, primitive North American gomphothere, and considering the stratigraphic position of the Douglas Mountain fauna, Peterson's Douglas Mountain fauna may be slightly older than the Cedar Springs Draw fauna. Peterson's locality at Douglas Mountain appears to be about midway stratigraphically in the formation. Peterson $(1928$, p. 93$)$ measured a section of $224.3 \mathrm{~m}$ from the base of the formation to the top of his fossil horizon, called by him the "Weller Horizon." The fossils of the Cedar Springs Draw fauna were collected from near the top of the formation in the white crossbedded sandstone unit. As mentioned previously, $510 \mathrm{~m}$ of Browns Park was drilled in the Texaco No. 1 State-K well, where the white, cross-bedded unit is exposed on the surface; core holes drilled in the white, crossbedded unit near localities D855 and D856 record a total depth for the Browns Park of $490-535 \mathrm{~m}$.

\section{ISOTOPIC AGE}

An ash near the D855 and D856 quarries gave a zircon fission-track age of $11.3 \pm 0.8 \mathrm{~m} . \mathrm{y}$. This ash (field no. 72G74) is about 1 mile northwest of D856, in the NW1/4SE1/4 sec. 25 , T. 6 N., R. 97 W. (fig. 10). The ash is exposed only at a single outcrop and cannot be traced south toward the D855 and D856 fossil localities owing
TABLE 17.-Fission-track age data for zircon microphenocrysts from the upper part of the Browns Park Formation, sample no. 72G74 [t, track; Ps, spontaneous track density; $\mathrm{Pi}$, induced track density; $F$, neutron fluence; $n$, neutron; $\mathrm{cm}$, centimeter; yrs, years. \pm is one sigma. Number of tracks counted in parentheses]

\begin{tabular}{clllc}
\hline $\begin{array}{c}\text { Sample } \\
\text { no. }\end{array}$ & $\begin{array}{l}P s \times 10^{6} \\
t / \mathrm{cm}^{2}\end{array}$ & $\begin{array}{c}P i \times 10^{7} \\
t / \mathrm{cm}^{2}\end{array}$ & $\begin{array}{l}\mathrm{F} \times 10^{15} \\
\mathrm{n} / \mathrm{cm}^{2}\end{array}$ & $\begin{array}{c}\text { Age } \times 10^{6} \\
\text { yrs }\end{array}$ \\
\hline $72 \mathrm{G} 74$ & $\begin{array}{l}1.88 \\
(189)\end{array}$ & $\begin{array}{l}1.03 \\
(900)\end{array}$ & 1.01 & $11.3 \pm 0.8$ \\
\hline
\end{tabular}

to plant cover. The topographic position of the ash projected into the level of the D855 quarry; thus, the ash lies about $15 \mathrm{~m}$ topographically below the D856 quarry. Table 17 gives fission-track age data for this ash.

This $11.3 \pm 0.8 \mathrm{~m} . \mathrm{y}$. age falls within the time range of latest Barstovian and early Clarendonian (Tedford, 1981 , fig. 2). This age is similar to those determined by Evernden and others $(1964$, p. 164) for the Fish Lake Valley, Cedar Mountain, and Avawatz faunas. As possible evidence for a close faunal relationship of D856 to Fish Lake Valley is the fact that the postcrania of the D856 cf. Protolabis are inseparable from the postcrania of Protolabis coartatus, which occurs at the Fish Lake Valley fauna and the slightly older Cedar Mountain fauna. The slightly younger Avawatz Mountain fauna (Henshaw, 1940) has a Michenia present and also $P$. coartatus-sized postcrania.

\section{REFERENCES CITED}

Adams, John, and Patton, Jean, 1979, Sebkha-dune deposition in the Lyons Formation (Permian), northern Front Range, Colorado: Mountain Geologist, v. 16, no. 2, p. 47-57.

Ahlbrandt, T. S., and Andrews, Sarah, 1978, Distinctive sedimentary features of cold-climate eolian deposits, North Park, Colorado: Palaeogeography, Palaeoclimatology, Palaeoecology, v. 25, p. 327-351.

Ahlbrandt, T. S., and Fryberger, S. G., 1980, Eolian deposits in the Nebraska Sand Hills: U.S. Geological Survey Professional Paper 1120-A, p. 1-24.

1981, Sedimentary features and significance of interdune deposits, in Ethridge, F. G., and Flores, R. M., eds., Recent and ancient nonmarine depositional environments; models for exploration: Society of Economic Paleontologists and Mineralogists Special Publication No. 31, p. 293-314.

Allen, J. R. L., 1965, A review of the origin and characteristics of recent alluvial sediments: Sedimentology, v. 5, no. 2, p. 91-191.

Andrews, Peter, Meyer, G. E., Pilbeam, D. R., Van Couvering, J. A., and Van Couvering, J. A. H., 1981, The Miocene fossil beds of Maboko Island, Kenya: Geology, age, taphonomy and paleontology: Journal of Human Evolution, v. 10, p. 35-48.

Barghoorn, S., 1981, Magnetic-polarity stratigraphy of the Miocene type Tesuque Formation, Santa Fe Group, in the Española Valley, New Mexico: Geological Society of America Bulletin, pt. I, v. 92, no. 12 , p. $1027-1041$. 
Behrensmeyer, A. K., 1975, The taphonomy and paleoecology of PlioPleistocene vertebrate assemblages east of Lake Rudolf, Kenya: Bulletin of the Museum of Comparative Zoology, Harvard University, v. 146 , no. 10 , p. $473-578$.

1978, Taphonomic and ecologic information from bone weathering: Paleobiology, v. 4, no. 2, p. 150-162.

Behrensmeyer, A. K., and Dechant-Boaz, D. E., 1980, The Recent bones of Amboseli National Park, Kenya, in relation to East African paleoecology, in Behrensmeyer, A. K., and Hill, A. P., eds., Fossils in the making, vertebrate taphonomy and paleoecology: University of Chicago Press, p. 72-92.

Berggren, W.A., Kent, D.V., Flynn, J.J., and Van Couvering, J.A., 1985, Cenozoic geochronology: Geological Society of America Bulletin, v. 96, p. 1407-1418.

Bergin, M. J., 1959, Preliminary geologic map of the Maybell-Lay area, Moffat County, Colorado: U.S. Geological Survey Open-File Report, scale 1:48,000.

Bergin, M. J., and Chisholm, W. A., 1956, Maybell-Lay area, Moffat County, Colorado: U.S. Geological Survey Trace Elements Investigations Report 620, p. 190-199.

Berry, C. T., 1938, A Miocene dog from Maryland: Proceedings of the U.S. National Museum, v. 85, p. 159-161.

Black, C. C., 1961, Fossil mammals from Montana-Part 1, Additions to the late Miocene Flint Creek Local Fauna: Annals of the Carnegie Museum, v. 36, art. 7, p. 69-76.

Bradley, W. H., 1936, Geomorphology of the north flank of the Uinta Mountains: U.S. Geological Survey Professional Paper 185-I, p. $163-204$.

Brownfield, M. E., and Anderson, Kevin, 1979, Geologic map and coal sections of the Lay SE Quadrangle, Moffat County, Colorado: U.S. Geological Survey Open-File Report 79-1680, scale $1: 24,000$.

Brownfield, M. E. and Prost, G. L., 1979, Geologic map and coal sections of the Lay Quadrangle, Moffat County, Colorado: U.S. Geological Survey Open-File Report 79-1679, scale 1:24,000.

Buffler, R. T., 1967, The Browns Park Formation and its relationship to the late Tertiary geologic history of the of the Elkhead region, northwestern Colorado-south-central Wyoming: Berkeley, Calif., University of California $\mathrm{Ph}$. D. thesis, $175 \mathrm{p}$.

Cassiliano, Michael, 1980, Stratigraphy and vertebrate paleontology of the Horse Creek-Trail Creek area, Laramie County, Wyoming: University of Wyoming Contributions to Geology, v. 19, no. 1, p. 25-68.

Chisholm, W. A., 1963, Effect of climate and source area location on Browns Park Formation petrology [abs.]: American Association of Petroleum Geologists Bulletin, v. 47, p. 353.

Chisholm, W. A., Bergin, M. A., and Pritchard, G. E., 1961, Sedimentary petrology and sedimentation of the Miocene Browns Park Formation, in Program Abstracts, Annual Meeting of the Society of Economic Paleontologists and Mineralogists, Denver, Colorado, p. 84-85.

Coe, Malcolm, 1980, The role of modern ecological studies in the reconstruction of paleoenvironments in Sub-Saharan Africa, in Behrensmeyer, A. K., and Hill, A. P., eds., Fossils in the making, vertebrate taphonomy and paleoecology: University of Chicago Press, p. 55-67.

Condon, Thomas, 1896, Scientific description of two new fossil dogs: University of Oregon Bulletin, v. 2, no. 6, p. 10-11.

Cook, H. J., 1965, Runningwater Formation, middle Miocene of Nebraska: American Museum Novitates, no. 2227, 8 p.

Cook, H. J., and Macdonald, J. R., 1962, New Carnivora from the Miocene and Pliocene of western Nebraska: Journal of Paleontology, v. 36 , no. 3 , p. $560-567$.

Cope, E. D., 1873, Third notice of extinct vertebrata from the Tertiary of the plains: Paleontological Bulletin, v. 16, 8 p.
1874, Report on the stratigraphy and Pliocene vertebrate paleontology of northern Colorado: Bulletin of the U.S. Geological Survey and Geographical Survey of the Territories (Hayden), v. 1, no. 1, p. 9-28.

1875, On some new fossil Ungulata: Proceedings of the Academy of Natural Sciences of Philadelphia, v. 27, p. 258-262.

1877, Report upon the extinct vertebrata obtained in New Mexico by parties of the expedition of 1874 , in Wheeler, G. M., Report upon United States geographical surveys west of the one hundredth meridian, v. 4-Paleontology, pt. 2, 372 p.

Crews, George, 1963, Geology of a part of northeast Moffat County, Colorado: Golden, Colo., Colorado School of Mines Masters thesis, $124 \mathrm{p}$.

Davidson, Pirie, 1923, Alticamelus alexandrae, a new camel from the Barstow Upper Miocene of the Mohave Desert: University of California Publications, Bulletin of the Department of Geological Sciences, v. 14 , no. 12 , p. 397-408.

Douglass, Earl, 1903, New vertebrates from the Montana Tertiary: Annals of the Carnegie Museum, v. 2, art. 5, p. 145-200.

1908, Rhinoceroses from the Oligocene and Miocene deposits of North Dakota and Montana: Annals of the Carnegie Museum, v. 4 , p. $256-266$.

Downs, Theodore, 1956, The Mascall fauna from the Miocene of Oregon: University of California Publications in Geological Sciences, v. 31 , no. 5 , p. $199-354$.

Dyni, J. R., 1968, Geologic map of the Elk Springs quadrangle, Moffat County, Colorado: U.S. Geological Survey Geologic Quadrangle Map GQ-702, scale 1:62,500.

Evernden, J. F., Savage, D. E., Curtis, G. H., and James, G. T., 1964, Potassium-argon dates and the Cenozoic mammalian chronology of North America: American Journal of Science, v. 262, no. 2, p. $145-198$.

Forsten, Ann, 1970, The Late Miocene Trail Creek mammalian fauna: University of Wyoming Contributions to Geology, v. 9, no. 1, p. 39-51.

Frailey, David, 1979, The large mammals of the Buda Local Fauna (Arikareean: Alachua County, Florida): Bulletin of the Florida State Museum, Biological Sciences, v. 24, no. 2, p. 123-173.

Frick, Childs, 1937, Horned ruminants of North America: Bulletin of the American Museum of Natural History, v. 69, 669 p.

Frick, Childs, and Taylor, B. E., 1968, A generic review of the stenomyline camels: American Museum Novitates, no. 2353, $51 \mathrm{p}$.

1971, Michenia, a new protolabine (Mammalia, Camelidae) and a brief review of the early taxonomic history of the genus Protolabis: American Museum Novitates, no. 2444, 24 p.

Furlong, E. L., 1927, The occurrence and phylogenetic status of Merycodus from the Mohave Desert Tertiary: University of California Publications, Bulletin of the Department of Geological Sciences, v. 17 , no. 4 , p. $145-186$.

1935, New merycodonts from the Upper Miocene of Nevada: Carnegie Institute of Washington Publication 453, p. 1-10.

Galbreath, E. C., 1953, A contribution to the Tertiary geology and paleontology of northeastern Colorado: University of Kansas Paleontological Contributions-Vertebrata, art. 4, no. 13, $119 \mathrm{p}$.

Galusha, Ted, 1966, The Zia Sand Formation, new early to medial Miocene beds in New Mexico: American Museum Novitates, no. $2271,12 \mathrm{p}$.

1975, Stratigraphy of the Box Butte Formation, Nebraska: Bulletin of the American Museum of Natural History, v. 156, art. 1, p. 1-68.

Galusha, Ted, and Blick, J. C., 1971, Stratigraphy of the Santa Fe Group, New Mexico: Bulletin of the American Museum of Natural History, v. 144, art. 1, p. 1-127. 
Gawne, C. E., 1981a, Sedimentology and stratigraphy of the Miocene Zia Sand of New Mexico-Summary: Geological Society of America Bulletin, pt. I, v. 92, p. 999-1007.

$1981 \mathrm{~b}$, Sedimentology and stratigraphy of the Miocene Zia Sand of New Mexico: Geological Society of America Bulletin, pt. II, v. 92, p. $2484-2552$.

Gazin, C. L., 1932, A Miocene mammalian fauna from southeastern Oregon: Carnegie Institution of Washington Publication 418, p. 37-86.

Getty, Robert, 1975, Sisson and Grossman's The anatomy of the domestic animals, v. 1: Philadelphia, W. B. Saunders Co., 1211 p.

Gidley, J. W., 1907, Revision of the Miocene and Pliocene Equidae of North America: Bulletin of the American Museum of Natural History, v. 23, art. 35, p. 865-934.

Glennie, K. W., 1970, Desert sedimentary environments, in Developments in Sedimentology, [v.] 14: Amsterdam, Elsevier Publishing Co., $222 \mathrm{p}$.

Gregory, J. T., 1942, Pliocene vertebrates from Big Spring Canyon, South Dakota: University of California Publications, Bulletin of the Department of Geological Sciences, v. 26, no. 4, p. 307-446.

Grutt, E. W. Jr., and Whalen, J. F., 1955, Uranium in northern Colorado and southern Wyoming, in Intermountain Association of Petroleum Geologists-Rocky Mountain Association of Geologists Guidebook, 6th Annual Field Conference, Northwest Colorado, p. $126-129$.

Hancock, E. T., 1925, Geology and coal resources of the Axial and Monument Butte Quadrangles, Moffat County, Colorado: U.S. Geological Survey Bulletin 757, 134 p.

Hansen, W. R., 1965, Geology of the Flaming Gorge area, UtahColorado-Wyoming: U.S. Geological Survey Professional Paper $490,196 \mathrm{p}$.

Harrison, J. A., 1979, Revision of the Camelinae (Artiodactyla, Tylopoda) and description of the new genus Alforjas: University of Kansas Paleontological Contributions, paper 95, $20 \mathrm{p}$.

Haynes, Gary, 1980, Evidence of carnivore gnawing on Pleistocene and Recent mammalian bone: Paleobiology, v. 6, no. 3, p. 341-351.

Henshaw, P. C., 1940, A Tertiary mammalian fauna from the Avawatz Mountains, San Bernardino County, California: Carnegie Institution of Washington Publication 514, p. 1-30.

1942, A Tertiary mammalian fauna from the San Antonio Mountains near Tonopah, Nevada: Carnegie Institution of Washington Publication 530, p. 77-168.

Hill, A. P., 1979, Disarticulation and scattering of mammal skeletons: Paleobiology, v. 5, no. 3, p. 261-274.

1980, Early postmortem damage to the remains of some contemporary East African mammals, in Behrensmeyer, A. K., and Hill, A. P., eds., Fossils in the making, vertebrate taphonomy and paleoecology: University of Chicago Press, p. 131-155.

Honey, J. G, 1977, The paleontology of the Browns Park Formation in the Maybell, Colorado area, and a taphonomic study of two fossil quarries in Colorado and Arizona: Tucson, Ariz., University of Arizona Masters thesis, 197 p.

Honey, J. G., and Taylor, B. E., 1978, A generic revision of the Protolabidini (Mammalia, Camelidae), with a description of two new protolabidines: Bulletin of the American Museum of Natural History, v. 161 , art. 3, p. 369-425.

Hook, D. L., 1956, Late Cenozoic stratigraphy and structure of a part of the Walnut Grove Basin, Yavapai County, Arizona: Tucson, Ariz., University of Arizona Masters thesis, $50 \mathrm{p}$.

Hunt, R. M. Jr., 1978, Depositional setting of a Miocene mammal assemblage, Sioux County, Nebraska (U.S.A.): Palaeogeography, Palaeoclimatology, Palaeoecology, v. 24, p. 1-52.

Izett, G. A., 1975, Late Cenozoic sedimentation and deformation in northern Colorado and adjoining areas: Geological Society of America Memoir 144, p. 179-209.
Izett, G. A., Denson, N. M., and Obradovich, J. D., 1970, K-Ar age of the lower part of the Browns Park Formation, northwestern Colorado: U.S. Geological Survey Professional Paper 700-C, p. C150-C152.

Izett, G. A., Honey, J. G., and Brownfield, M. E., 1985, Geologic map of the Citadel Plateau quadrangle, Moffat County, Colorado: U.S. Geological Survey Miscellaneous Geologic Investigations Map I-1532, scale 1:48,000.

Leidy, Joseph, 1858, Notice of remains of extinct Vertebrata, from the valley of the Niobrara River, collected during the exploring expedition of 1857 , in Nebraska, under the command of Lieut. G. K. Warren, U.S. Top. Engineer, by Dr. F. V. Hayden, Geologist to the exedition: Proceedings of the Academy of Natural Sciences of Philadelphia, v. 10, p. 20-29.

1869, The extinct mammalian fauna of Dakota and Nebraska, including an account of some allied forms from other localities, together with a synopsis of the mammalian remains of North America, illustrated with 30 plates: Journal of the Academy of Natural Sciences of Philadelphia, vol. 7, second series, p. 22-472.

Lewis, G. E., 1968, Stratigraphic paleontology of the Barstow Formation in the Alvord Mountain area, San Bernardino County, California: U.S. Geological Survey Professional Paper 600-C, p. C75-C79.

Lewis, W. S., 1977, Geology of uranium mineralization in the Browns Park Formation, Carbon County, Wyoming and Moffat County, Colorado: Golden, Colo., Colorado School of Mines Masters thesis, $85 \mathrm{p}$.

Loomis, F. B., 1910, Osteology and affinities of the genus Stenomylus: American Journal of Science, ser. 4, v. 29, p. 297-323.

Loring, S. H., and Wood, A. E., 1969, Deciduous premolars of some North American Tertiary camels (Family Camelidae): Journal of Paleontology, v. 43, no. 5, p. 1199-1209.

Love, J. D., 1961, Split Rock Formation (Miocene) and Moonstone Formation (Pliocene) in Central Wyoming: U.S. Geological Survey Bulletin 1121-I, p. I1-I39.

Luft, S. J., and Thoen, W. L., 1981, Measured sections of the Browns Park Formation (Miocene) in Moffat County, Colorado, 1980: U.S. Geological Survey Open-File Report 81-171, 35 p.

Lugn, A. L., 1938, The Nebraska State Geological Survey and the "Valentine Problem": American Journal of Science, ser. 5, v. 36 , p. 220-227.

Macdonald, J. R., 1949, A new Clarendonian fauna from northeastern Nevada: University of California Publications, Bulletin of the Department of Geological Sciences, v. 28, no. 7, p. 173-194.

Marsh, O. C., 1874, Notice of new equine mammals from the Tertiary formation: American Journal of Science, ser. 3, v. 7, p. 247-258.

Matthew, W. D., 1904, A complete skeleton of Merycodus: Bulletin of the American Museum of Natural History, v. 20, p. 101-129. 1907, A Lower Miocene fauna from South Dakota: Bulletin of the American Museum of Natural History, v. 23, art. 9, p. $169-219$

1909, Faunal lists of the Tertiary Mammalia of the West, in Osborn, H. F., Cenozoic mammal horizons of western North America: U.S. Geological Survey Bulletin 361, p. 91-120.

1918, Contributions to the Snake Creek fauna: Bulletin of the American Museum of Natural History, v. 38, art. 7, p. 183-229. 1924, Third contribution to the Snake Creek fauna: Bulletin of the American Museum of Natural History, v. 50, p. 59-210. 1932, A review of the rhinoceroses with a description of Aphelops material from the Pliocene of Texas: University of California Publications, Bulletin of the Department of Geological Sciences, v. 20, no. 12 , p. 411-482.

Matthew, W. D., and Cook, H. J., 1909, A Pliocene fauna from western Nebraska: Bulletin of the American Museum of Natural History, v. 26 , art. 27, p. 361-414. 
Matthew, W. D., and Macdonald, J. R., 1960, Two new species of $O x$ ydactylus from the middle Miocene Rosebud Formation in western South Dakota: American Museum Novitates, no. 2003, 7 p.

Mawby, J. E., 1968, Megahippus and Hypohippus (Perissodactyla, Mammalia) from the Esmeralda Formation of Nevada: PaleoBios, no. 7,13 p.

McGrew, P. O., 1935, A new Cynodesmus from the Lower Pliocene of Nebraska with notes on the phylogeny of the dogs: University of California Publications, Bulletin of the Department of Geological Sciences, v. 23, no. 10, p. 305-312.

1938, The Burge fauna, a Lower Pliocene mammalian assemblage from Nebraska: University of California Publications, Bulletin of the Department of Geological Sciences, v. 24, no. 11, p. $309-328$.

1951, Tertiary stratigraphy and paleontology of south-central Wyoming: Wyoming Geological Association Guidebook, 6th Annual Field Conference, p. 54-57.

McKay, E. J., 1974, Geologic map of the Lone Mountain quadrangle, Moffat County, Colorado: U.S. Geological Survey Geologic Quadrangle Map GQ-1144, scale 1:62,500.

McKay, E. J., and Bergin, M. J., 1974, Geologic map of the Maybell quadrangle, Moffat County, Colorado: U.S. Geological Survey Geologic Quadrangle Map GQ-1145, scale 1:62,500.

McKee, E. D., 1966, Structures of dunes at White Sands National Monument, New Mexico (and a comparison with structures of dunes from other selected areas): Sedimentology, v. 7, no. 1, p. 1-69. 1979. Ancient sandstones considered to be eolian, ch. $\mathrm{H}$ of McKee, E. D., ed., A study of global sand seas: U.S. Geological Survey Professional Paper 1052, p. 187-238.

McKee, E. D., and Bigarella, J. J., 1979, Sedimentary structures in dunes (with sections on the Lagoa dune field, Brazil), ch. E of McKee, E. D., ed., A study of global sand seas: U.S. Geological Survey Professional Paper 1052, p. 83-134.

McKee, E. D., Crosby, E. J., and Berryhill, H. L., 1967, Flood deposits, Bijou Creek, Colorado, June 1965: Journal of Sedimentary Petrology, v. 37 , no. 3 , p. $829-851$.

McKee, E. D., and Tibbitts, G. C., Jr., 1964, Primary structures of a seif dune and associated deposits in Libya: Journal of Sedimentary Petrology, v. 34, p. 5-17.

Merriam, J. C., 1911, Tertiary mammal beds of Virgin Valley and Thousand Creek in northwestern Nevada: University of California Publications, Bulletin of the Department of Geological Sciences, v. 6 , no. 11 , p. 199-304.

1913, Notes on the canid genus Tephrocyon: University of California Publications, Bulletin of the Department of Geological Sciences, v. 7 , no. 18 , p. 359-372.

1916, Tertiary vertebrate fauna from the Cedar Mountain region of western Nevada: University of California Publications, Bulletin of the Department of Geological Sciences, v. 9, no. 13, p. 161-198.

Munthe, Jens, 1979, Summary of Miocene vertebrate fossils of the Granite Mountains Basin, central Wyoming: University of Wyoming Contributions to Geology, v. 18, no. 1, p. 33-46.

Olsen, S. J., 1956, The Caninae of the Thomas Farm Miocene: Breviora, no. $66,12 \mathrm{p}$.

Osborn, H. F., 1918, Equidae of the Oligocene, Miocene, and Pliocene of North America, iconographic type revision: Memoir of the American Museum of Natural History (new series), v. 2, pt. 1, $330 \mathrm{p}$.

1936, Proboscidea; a monograph of the discovery, evolution, migration and extinction of the mastodonts and elephants of the world, vol. 1, Moeritheroidea, Deinotherioidea, Mastodontoidea: American Museum of Natural History, New York, 802 p.

Patton, T. H., 1969, Miocene and Pliocene artiodactyls, Texas Gulf Coastal Plain: Bulletin of the Florida State Museum, Biological Sciences, v. 14 , no. 2 , p. $115-226$.
Peterson, O. A., 1906, The Miocene beds of western Nebraska and eastern Wyoming and their vertebrate faunae: Annals of the Carnegie Museum, v. 4, art. 3, p. 21-72.

1924, Discovery of fossil mammals in the Brown's Park Formation of Moffat County, Colorado: Annals of the Carnegie Museum, v. 15, art. 12, p. 299-304.

1928, The Brown's Park Formation: Carnegie Museum Memoir 11 , no. 2, p. 87-121.

Powell, J. W., 1876, Report on the geology of the eastern portion of the Uinta Mountains and a region of country adjacent thereto: U.S. Geological and Geographical Survey of the Territories, v. 7, p. 1-218.

Reheis, M. C., 1981, Geologic map and coal resources of the Easton Gulch Quadrangle, Moffat County, Colorado: U. S. Geological Survey Coal Investigations Map C-87, scale 1:24,000.

Rowley, P. D., Tweto, Ogden, Hansen, W. R., and Carrara, P. E., 1979, Geologic map of the Vernal $1^{\circ} \times 2^{\circ}$ quadrangle, Colorado, Utah and Wyoming: U.S. Geological Survey Miscellaneous Field Studies Map MF-1163, scale 1:250,000.

Schultz, C. B., 1938, The Miocene of western Nebraska: American Journal of Science, vol. 35, p. 441-444.

Scott, W. B., 1893, The mammals of the Deep River beds: American Naturalist, v. 27, p. 659-662.

Sears, J. D., 1924a, Relations of the Browns Park Formation and the Bishop Conglomerate, and their role in the origin of the Green and Yampa Rivers: Geological Society of America Bulletin, no. 35 , p. 279-304.

1924b, Geology and oil and gas prospects of part of Moffat County, Colorado, and southern Sweetwater County, Wyoming: U.S. Geological Survey Bulletin 751-G, p. 269-319.

Sellards, E. H., 1916, Fossil vertebrates from Florida: a new Miocene fauna; new Pliocene species; the Pleistocene fauna: Florida State Geological Survey, 8th Annual Report, p. 77-119.

Simpson, G. G., 1932, Miocene land mammals from Florida: Florida State Geological Survey Bulletin 10, p. 7-41.

Skinner, M. F., 1942, The fauna of Papago Springs Cave, Arizona, and a study of Stockoceros; with three new antilocaprines from Nebraska and Arizona: Bulletin of the American Museum of Natural History, v. 80 , art. 6, p. 143-220.

1968, A Pliocene chalicothere from Nebraska, and the distribution of chalicotheres in the late Tertiary of North America: American Museum Novitates, no. 2346, 24 p.

Skinner, M. F., and Johnson, F. W., 1984, Tertiary stratigraphy and the Frick collection of fossil vertebrates from north-central Nebraska: Bulletin of the American Museum of Natural History, v. 178 , art. 3 , p. $217-368$.

Skinner, M. F., Skinner, S. M., and Gooris, R. J., 1968, Cenozoic rocks and faunas of Turtle Butte, south-central South Dakota: Bulletin of the American Museum of Natural History, v. 138, art. 7, p. $379-436$.

1977, Stratigraphy and biostratigraphy of late Cenozoic deposits in central Sioux County, western Nebraska: Bulletin of the American Museum of Natural History, v. 158, art. 5, p. 265-371.

Skinner, M. F., and Taylor, B. E., 1967, A revision of the geology and paleontology of the Bijou Hills, South Dakota: America Museum Novitates, no. $2300,53 \mathrm{p}$.

Stirton, R. A., 1929, Artiodactyla from the fossil beds of Fish Lake Valley, Nevada: University of California Publications, Bulletin of the Department of Geological Sciences, v. 18, no. 11, p. 291-302.

Tedford, R. H., 1970, Principles and practices of mammalian geochronology in North America, in Proceedings of the North American Paleontological Convention (Chicago, 1969), pt. F, correlation by fossils: Lawrence, Kansas, Allen Press, Inc., p. 666-703. 
1981, Mammalian biochronology of the late Cenozoic basins of New Mexico: Geological Society of America Bulletin, pt. I, v. 92, p. 1008-1022.

Tedford, R. H., and Alf, R. M., 1962, A new Megahippus from the Barstow Formation, San Bernardino County, California: Southern California Academy of Science Bulletin, v. 61, pt. 2, p. 113-122.

Tedford, R. H., and Hunter, M. E., 1984, Miocene marine-nonmarine correlations, Atlantic and Gulf Coastal Plains, North America: Palaeogeography, Palaeoclimatology, Palaeoecology, v. 47, p. $129-151$.

Tobien, Heinz, 1973, On the evolution of mastodonts (Proboscidea, Mammalia)-part 1, The bunodont trilophodont groups: Notizblatt des Hessischen Landesamte fuer Bodenforschung (Wiesbaden), v. 101, p. $202-276$.

Tweto, Ogden, 1979, Geologic map of Colorado: U.S. Geological Survey, scale 1:500,000.

Untermann, G. E., and Untermann, B. R., 1954, Geology of Dinosaur National Monument and vicinity, Utah-Colorado: Utah Geological and Mineralogical Survey Bulletin 42, p. 1-221.

Voorhies, M. R., 1965, The Carnivora of the Trail Creek fauna: University of Wyoming Contributions to Geology, v. 4, no. 1, p. 21-25.

1969, Taphonomy and population dynamics of an early Pliocene vertebrate fauna, Knox County, Nebraska: University of Wyoming Contributions to Geology, Special Paper 1, p. 1-69.

Webb, S. D., 1969, The Burge and Minnechaduza Clarendonian mammalian faunas of north-central Nebraska: University of California Publications in Geological Sciences, v. 78, p. 1-191.

1973, Pliocene pronghorns of Florida: Journal of Mammalogy, v. 54 , no. 1, p. $203-221$.
Western, David, 1980, Linking the ecology of past and present mammal communities, in Behrensmeyer, A. K., and Hill, A. P., eds., Fossils in the making, vertebrate taphonomy and paleoecology: University of Chicago Press, p. 41-55.

White, T. E., 1941, Additions to the Miocene fauna of Florida: New England Zoological Club Proceedings, v. 18, p. 91-98.

1942, The Lower Miocene mammal fauna of Florida: Bulletin of the Museum of Comparative Zoology, Harvard University, v. 92 , no. 1, p. 1-49.

Williams, G. E., 1971, Flood deposits of the sand-bed ephemeral streams of central Australia: Sedimentology, v. 17, p. 1-40.

Wilson, J. A., 1939, A new species of dog from the Miocene of Colorado: Contributions from the Museum of Paleontology, University of Michigan, v. 5 , no. 12 , p. $315-318$.

1960, Miocene carnivores, Texas Coastal Plain: Journal of Paleontology, v. 34 , no. 5 , p. $983-1000$.

Winkler, G. R., 1970, Sedimentology and geomorphic significance of the Bishop Conglomerate and the Browns Park Formation, eastern Uinta Mountains, Utah, Colorado, and Wyoming: Salt Lake City, University of Utah Masters thesis, $115 \mathrm{p}$.

Wood, H. E., II, Chaney, R. W., Clark, J., Colbert, E. H., Jepsen, G. L., Reeside, J. B., Jr., and Stock, C., 1941, Nomenclature and correlation of the North American continental Tertiary: Geological Society of America Bulletin, v. 52, no. 1, p. 1-48.

Wortman, J. L., 1898, The extinct camelidae of North American and some associated forms: Bulletin of the American Museum of Natural History, v. 10, art. 7, p. 93-142. 